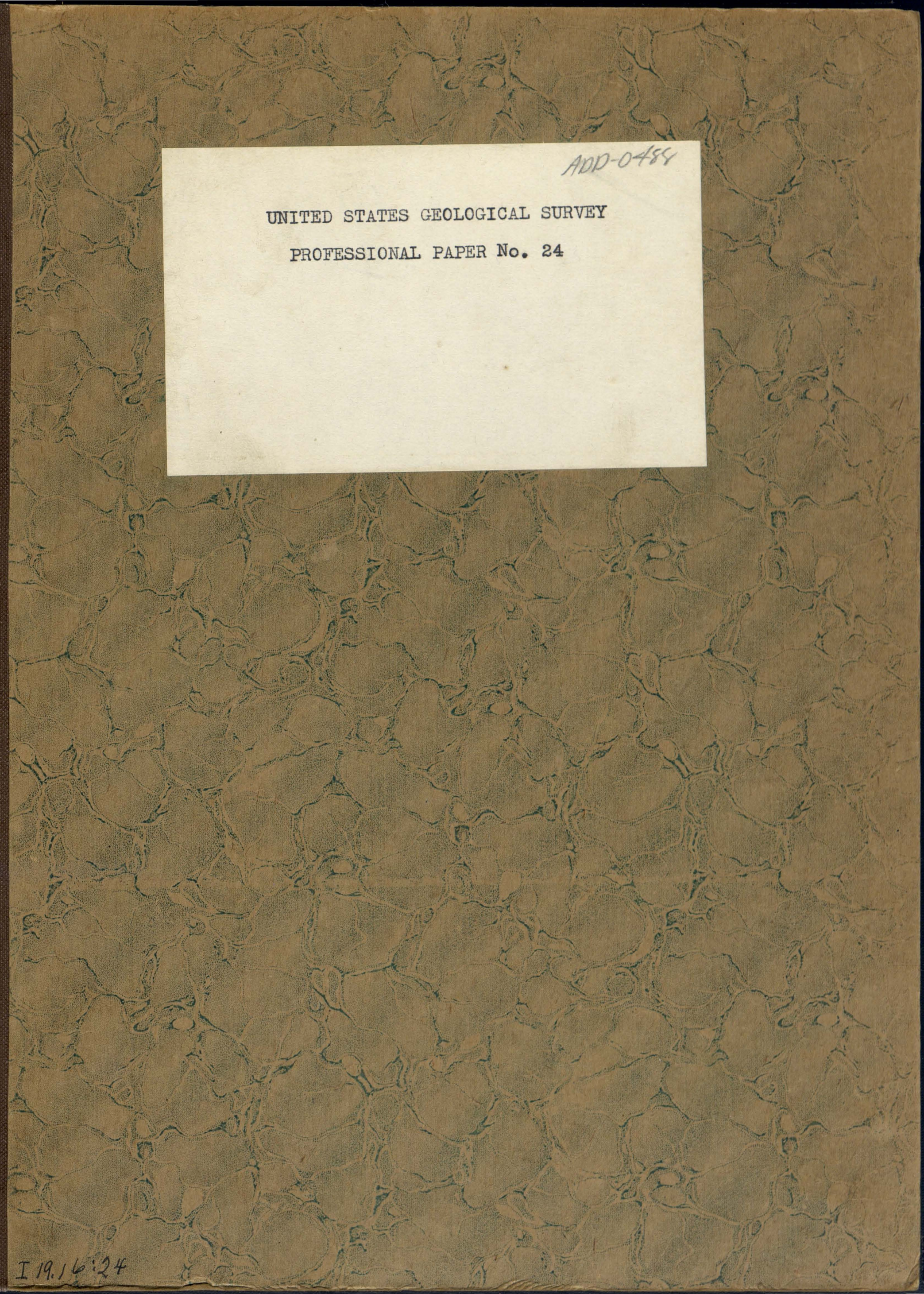




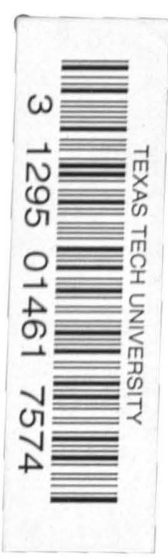


DEPARTMENT OF THE INTERIOR

UNITED STATES GEOLOGICAL SURVEY

CHARLES D. WALCOTT, DIRECTOR

\section{ZINC AND LEAD DEPOSTS OF NORTHERN ARKANSAS}

BY

GEORGE I. ADAMS

AGSISTED BY

A. H. PURDUE AND E. F. BUROHARD

WITH A BECTION ON THE

DETERMINATION AND CORRELATION OF FORMATIONS

BY

E. O. UIRICH

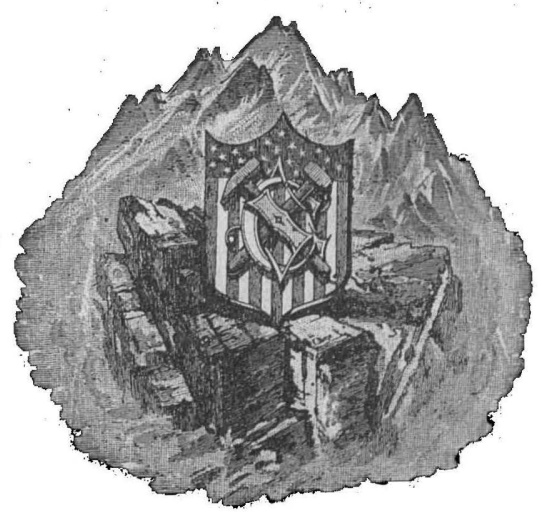

WASHINGTON

GOVHRNMENT PRINTING OEIOE

100.4 



\section{0 N T E N T S.}

Page.

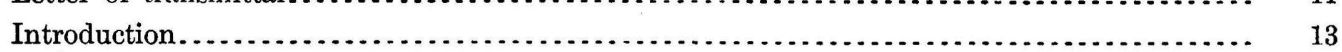

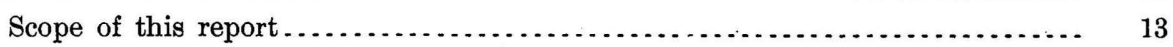

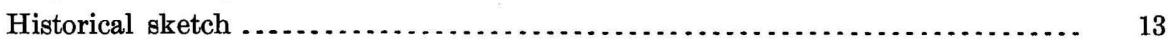

Limits of the northern Arkansas district ............................ 14

Transportation facilities.................................................... 14

Production of the district........................................ 15

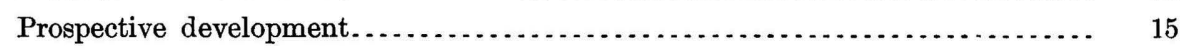

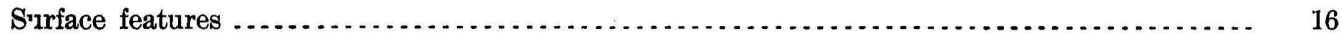

General character of the country .................................... 16

Physiographic relations of the Ozark Plateau and Boston Mountains.......... 16

Divisions of the Ozark Plateau ....................................... 17

Lowlands ............................................................... 17

Previous surface features............................................. 17

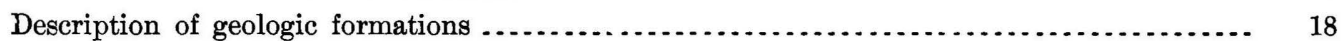

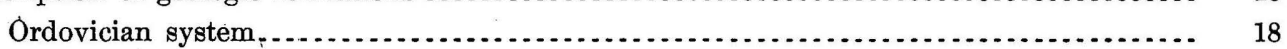

Yellville formation . . .

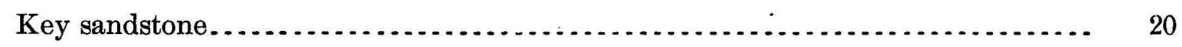

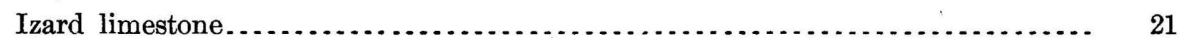

Polk Bayou limestone ........................................... 22

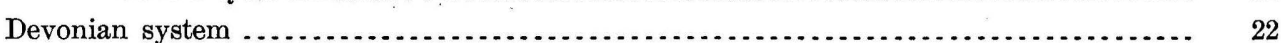

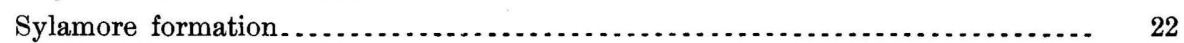

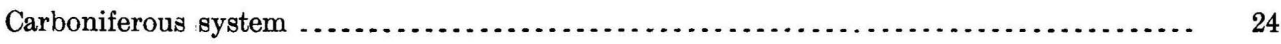

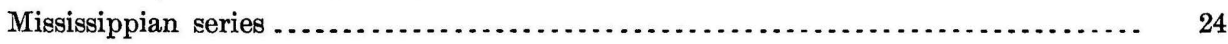

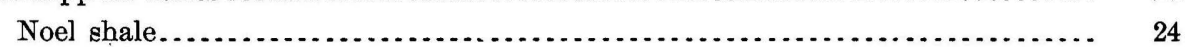

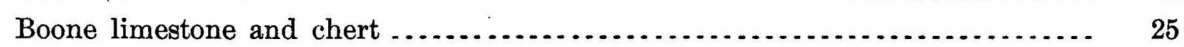

Moorefield shale .................................................... 26

Batesville sandstone .................................................. 26

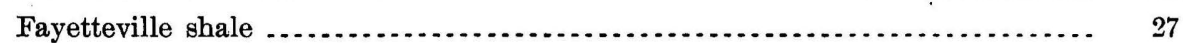

Pitkin limestone..................................................... 27

Pennsylvanian series. . . .

Morrow formation ................................................ 28

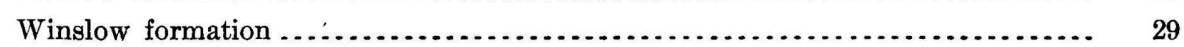

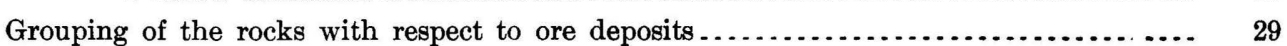




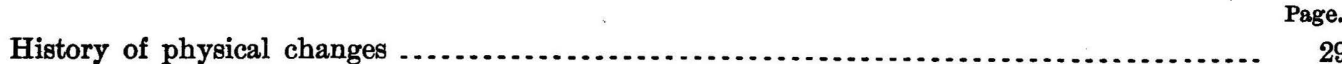

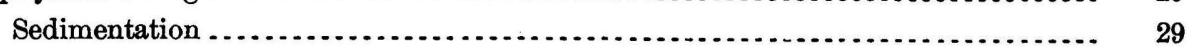

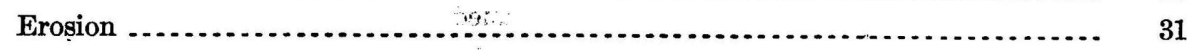

Deformation ............................................................. 32

Origin of structure.......................................................... 33

Geologic conditions influencing circulation of ground water ................. 34

Synclines.......................................................... 35

Relations of belt of weathering and belt of cementation.................. 35

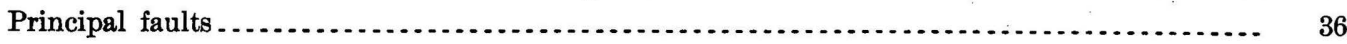

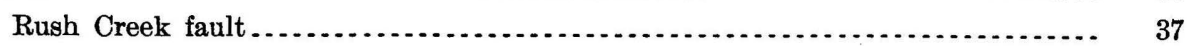

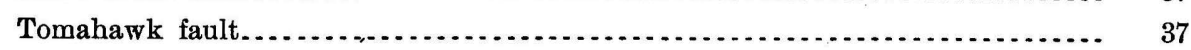

Pilot Mountain fault............................................... 37

St. Joe fault....................................................... 38

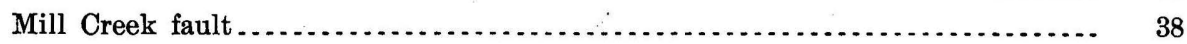

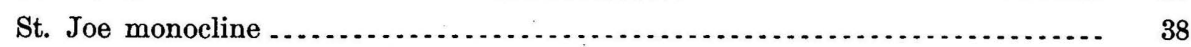

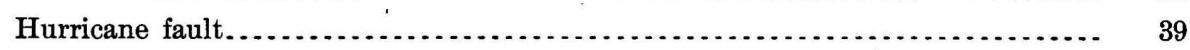

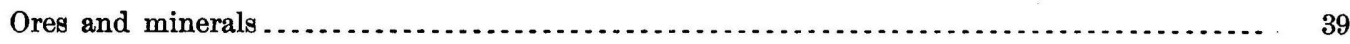

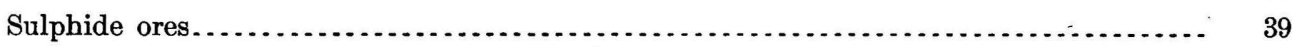

Zinc sulphide, or sphalerite ........................................ 39

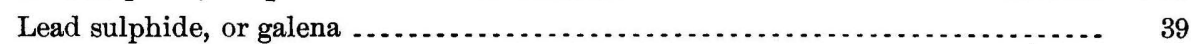

Oxidized ores. . .

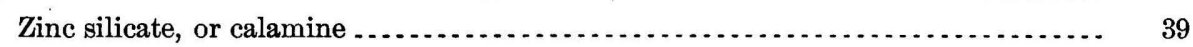

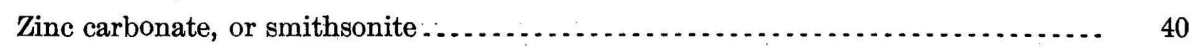

Hydrozincite ....................................................... 40

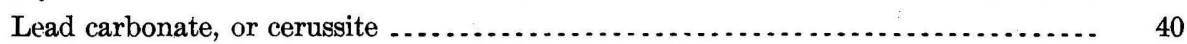

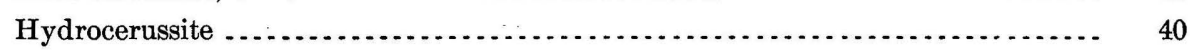

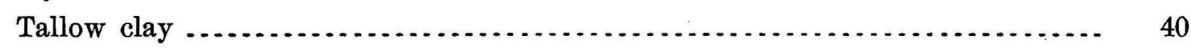

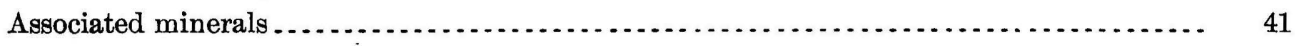

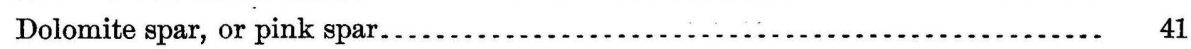

Calcite, or tiff..................................................... 41

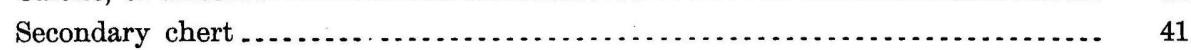

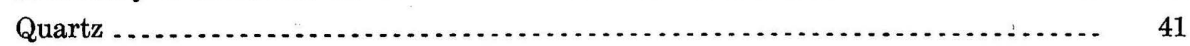

Iron sulphide, or pyrite........................................... 41

Chalcopyrite........................................................ 42

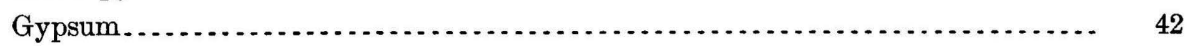

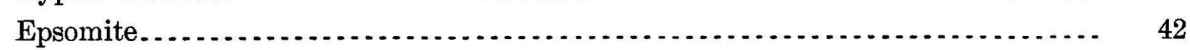

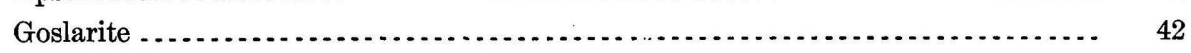

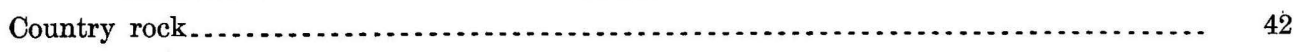

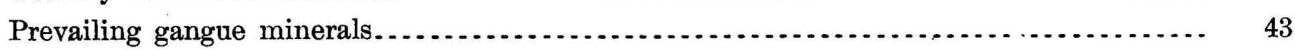

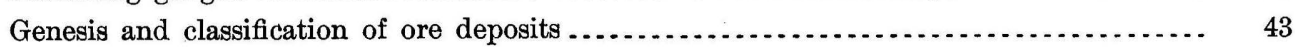

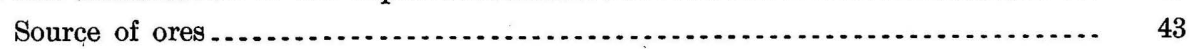

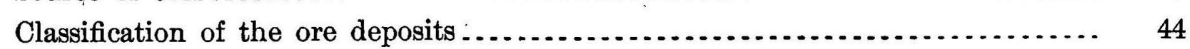

Processes of primary deposition of the sulphide ores ..................... 44

Processes of deposition of the oxidized ores ........................... 44

Secondary deposition of the sulphides................................. 45 
Ores and minerals-Continued.

Genesis and classification of ore deposits-Continued.

deposits associated with secondary chert............................ 45

Sulphide deposits in bedded breccias................................. 46

Sulphide deposits in fissures ........................................... 46

Sulphide deposits in fault breccias ....................................... 46

Sulphide ore in the country rock ...................................... 46

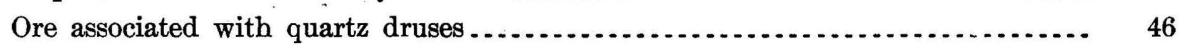

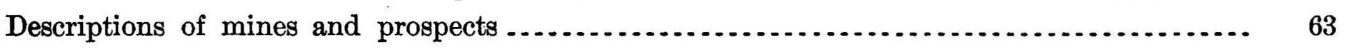

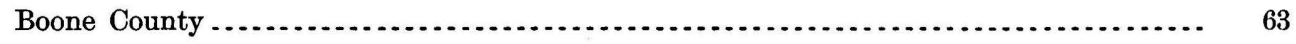

Northern Star.......................................................... 63

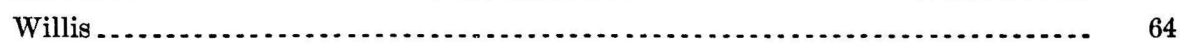

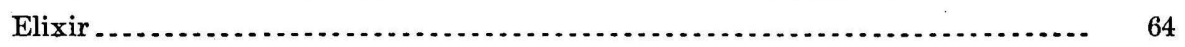

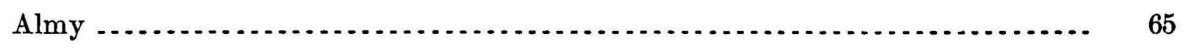

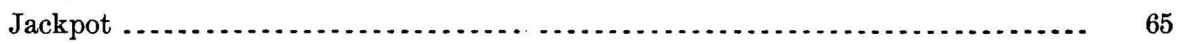

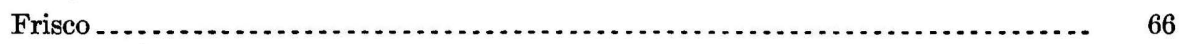

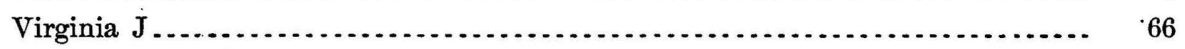

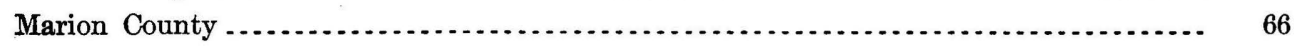

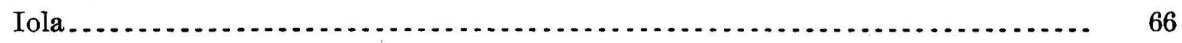

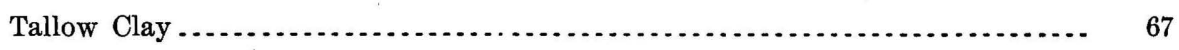

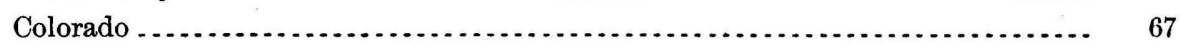

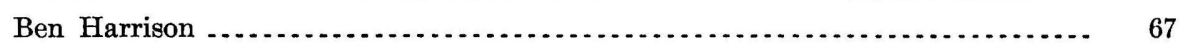

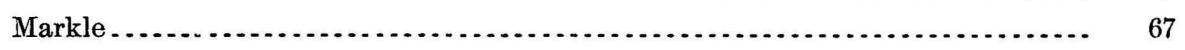

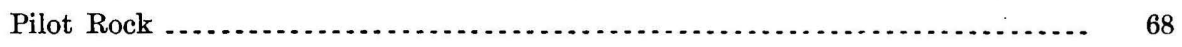

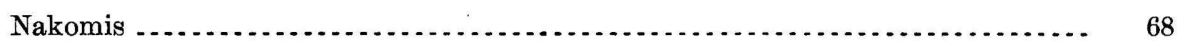

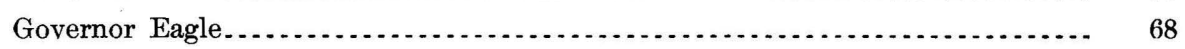

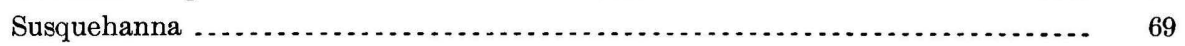

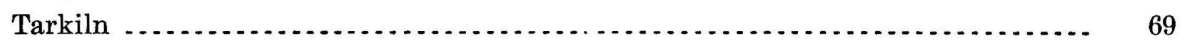

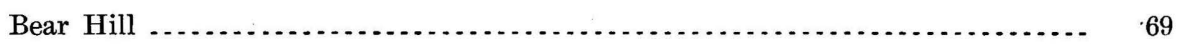

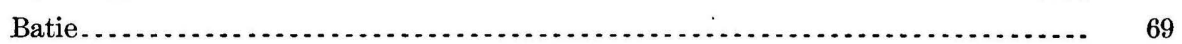

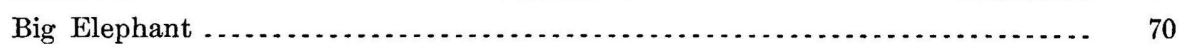

Big Buffalo......................................................... 70

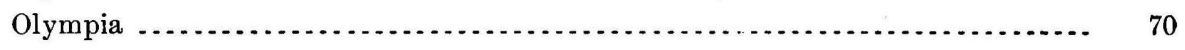

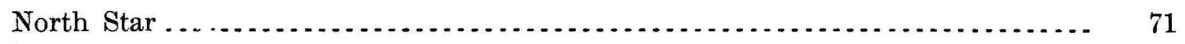

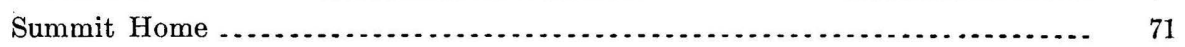

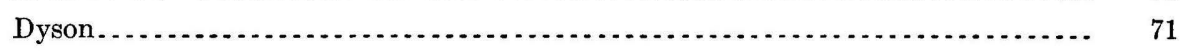

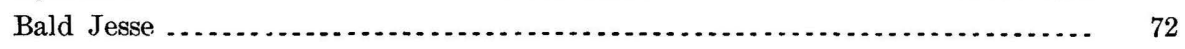

Hawkeye............................................................... 72

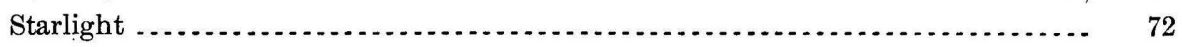

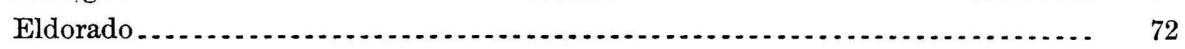

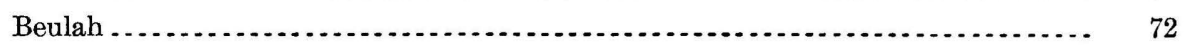

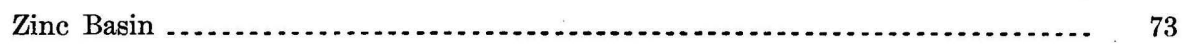

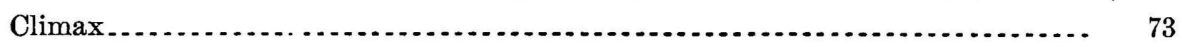

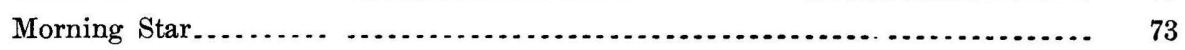

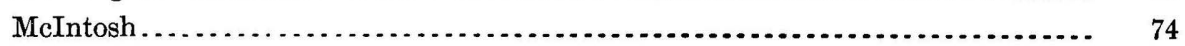


Description of mines and prospects-Continued.

Marion County-Continued.

White Eagle

Page.

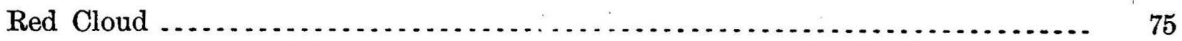

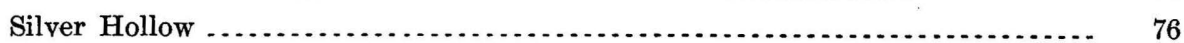

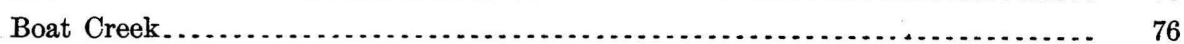

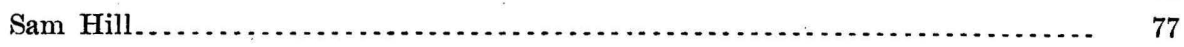

Bonanza . . . . . . . . .

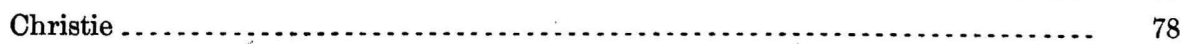

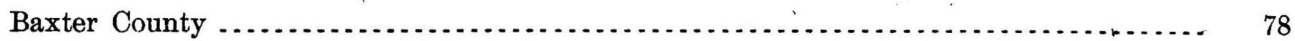

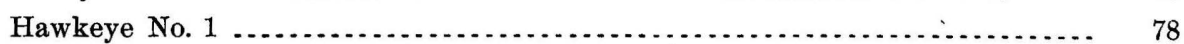

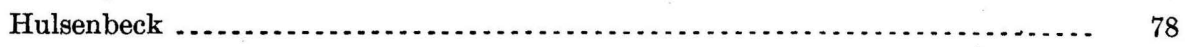

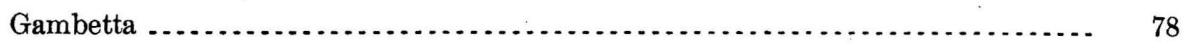

Lost Mine . . . . . . . . . . . .

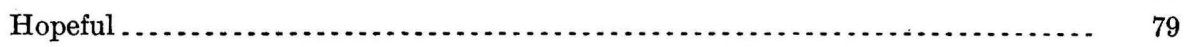

Bald Dave . . . . . . .

Gold Standard and Mark Hanna ....... . . . . . . . . . . . . . . . . . . . . . . . . 79

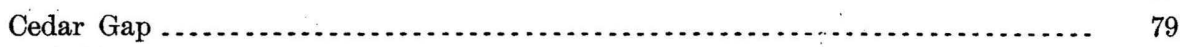

Hawkeye No. 2 . . . . . . . . . . . . . . . . . . . . . . . . . . . . . . . . . . . . 79

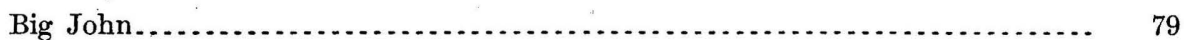

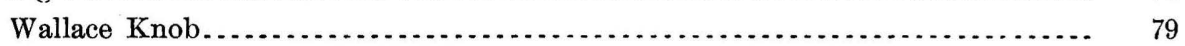

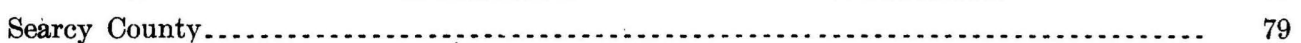

Winchester................

Jackpot (on Buffalo Fork) .................................. 80

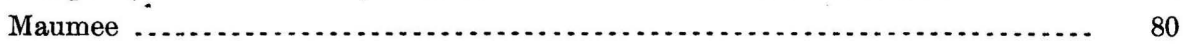

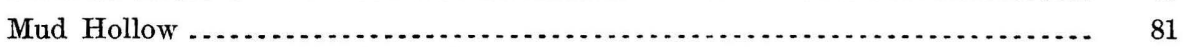

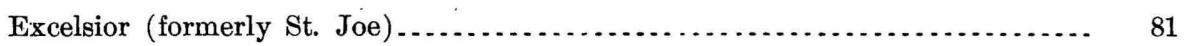

Davy Crockett. . . . .

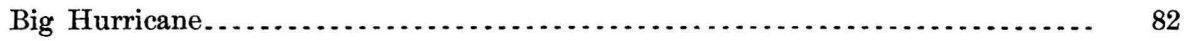

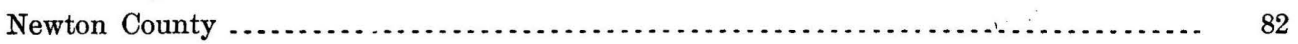

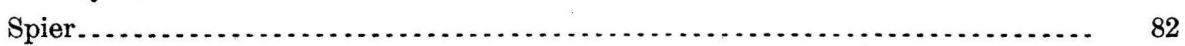

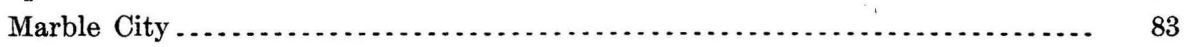

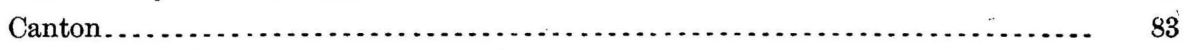

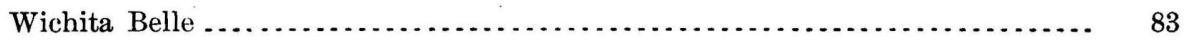

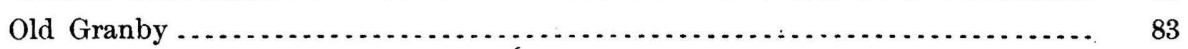

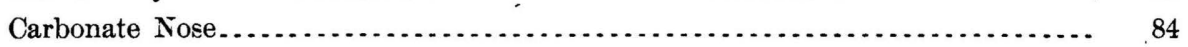

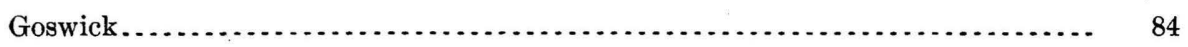

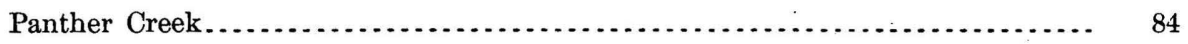

Chimney Rock . . . . . . . . . . . .

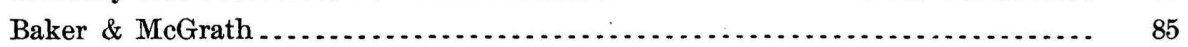

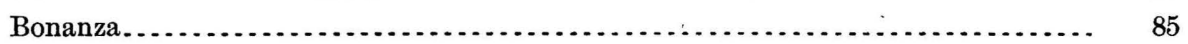

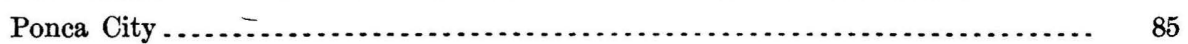

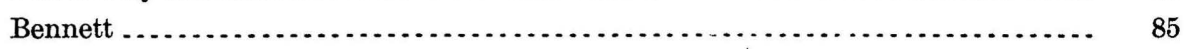

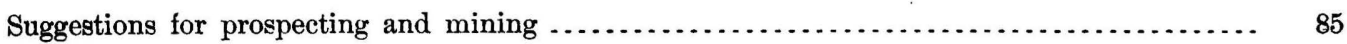

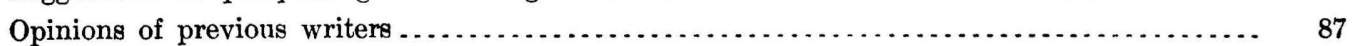


Determination and Correlation of Formations, by E. O. Ulrich..................... 90

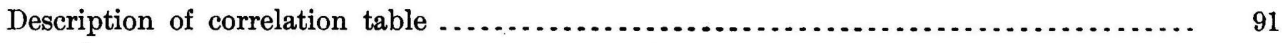

Evidence upon which the correlations are based ................................ 93

Ordovician formations .......................................................... 93

Yellville limestone .............................................. 93

Key sandstone................................................... 95

Izard limestone.......................................................... 97

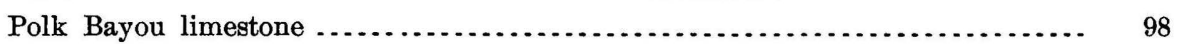

Silurian formations ......................................................... 98

St. Clair limestone............................................... 98

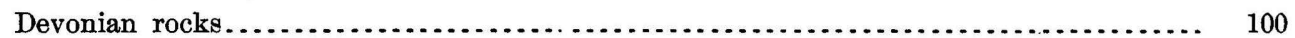

Sylamore formation................................................ 100

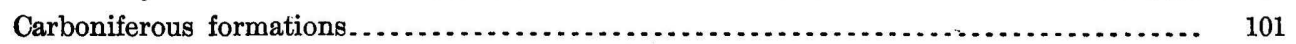

Lower Mississippian formations ......................................... 101

Noel shale and Boone limestone..................................... 101

Upper Mississippian formations .......................................... 102

Moorefield shale (Fayetteville shale in part of Branner) ................... 102

Batesville sandstone (Batesville sandstone of Branner, not Simonds; Wyman

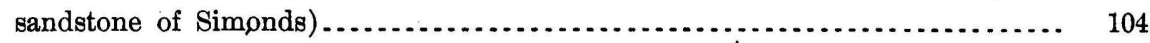

Fayetteville shale (Fayetteville shale of Simonds and Branner and Marshall

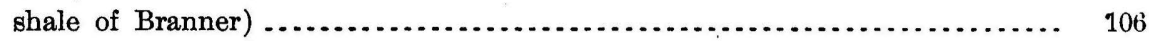

Wedington sandstone (Batesville sandstone of Simonds) $\ldots \ldots \ldots \ldots \ldots \ldots \ldots, 108$

Pitkin limestone.................................................. 109

Early Pennsylvanian formations...................................... 109

Morrow formation ............................................. 109

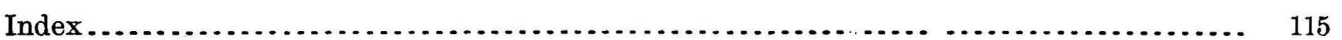





\section{ILLUSTRATIO N .}

Plate I. Map of north Arkansas zinc and lead district, showing general geology and principal

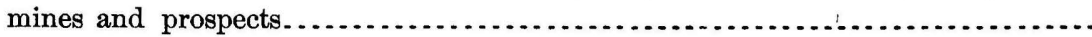

II. $A$, Sketch map of the Ozark region, showing the drainage and topography; $B$, Sketch map of the Ozark region, showing physiographic features ..............

III. A, Escarpment of Halls Mountain, 5 miles distant, seen from the north looking across Crooked Creek Valley; $B$, Bottom land along White River, near Gasville, looking northwest from mountain east of Dentons Ferry ................... 16

IV. Geologic map of the northern part of the Yellville quadrangle, Arkansas.......... 18

V. Geologic map of the southern part of the Yellville quadrangle, Arkansas. ......... 20

VI. $A$, Richmond Bluff, near Amos post-office, in Baxter County; $B$, Engles Bluff,

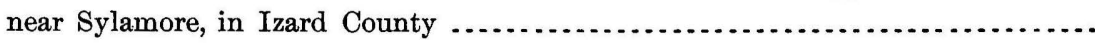

VII. $A$, Ledge of St. Joe limestone member; $B$, Ledge of Key sandstone...............

VIII. $A$, Mass of silicified breccia marking the St. Joe fault, near the Excelsior mine; $B$, Near view of dolomite breccia, cemented with pink spar.................. 34

IX. Hand specimens illustrating genesis of ores............................... 48

$\mathrm{X}$. Hand specimens illustrating genesis of ores. . . .

XI. Hand specimens illustrating genesis of ores................................ 52

XII. Hand specimens illustrating genesis of ores................................. 54

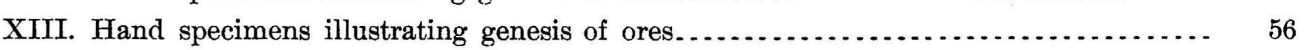

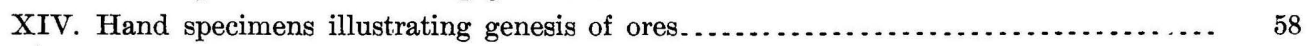

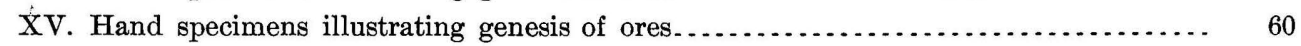

XVI. Hand specimens illustrating genesis of ores. ............................... 62

XVII. $A$, Open cut in barren ground near Iola mine, showing jointed dolomite; $B$,

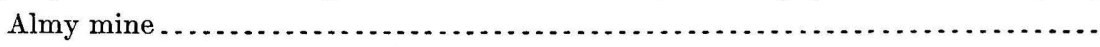

XVIII. A, Open cut Big Elephant mine, Key sandstone in upper part of exposure; $B$, Markle mine hand jigs ........................................... 68

XIX. $A$, Nakomis mine; $B$, Susquehanna mine...................................... 68

XX. $A$, Bear Hill mine; $B$, Beulah mine ..................................... 70

XXI. $A$, Climax mine; $B$, Morning Star mill, connected with mine above by gravity

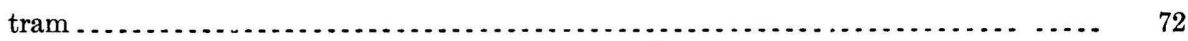

XXII. View of Rush post-office and Morning Star mine and mill ....................

XXIII. $A$, East end of main cut at Morning Star mine, showing fissure opposite end of track; $B$, McIntosh mill; connected with mine above by cable tram ..............

XXIV. McIntosh mine, Rush, Ark., showing natural exposure of rocks somewhat

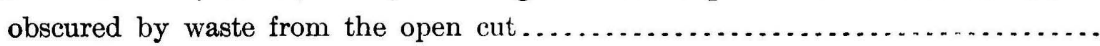

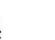

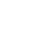

54
6
5
6
6




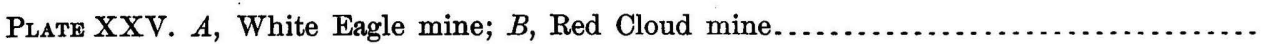

XXVI. $A$, Open cut, Hulsenbeck property; $B$, Fissure and shaft house at Baker and

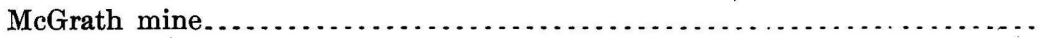

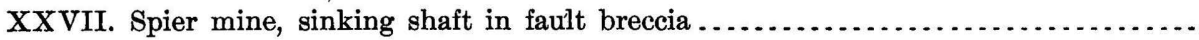

FIG. 1. Generalized section through the zinc and lead district, showing geologic relations of ore-bearing horizons and former extension of formations which have been removed

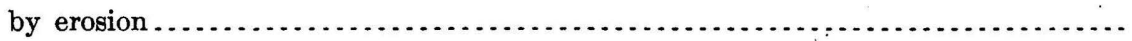

2. Diagram to show how stress may produce differential movement and brecciation as a result of variation in the character of the rocks acted upon ...............

3. General structural section showing relations of the Ozark region to the Arkansas

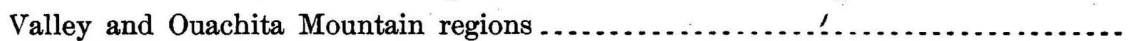

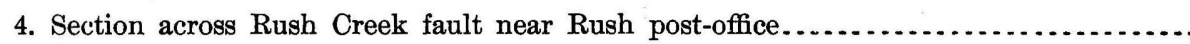

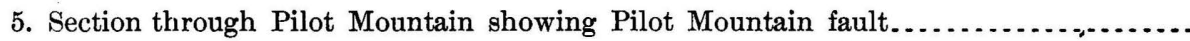

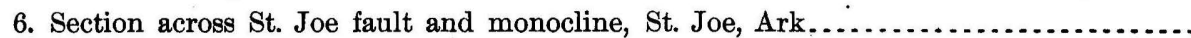




\section{LETTER OF TRANSMITTAL.}

\section{Department of the INTERIOR,}

\section{U. S. Geological Survex,}

Washington, D. C., November $24,1903$.

SIR: I have the honor to transmi, herewith the manuscript of a report on the zinc and lead deposits of northern Arkansas, by George I. Adams, assisted by A. H. Purdue and E. F. Burchard, with a section on the determination and correlation of formations, by E. O. Ulrich, and to recommend that it be published as a professional paper.

The report covers the whole of the Yellville quadrangle, for which a geologic folio is in preparation, together with portions of three adjacent quadrangles. It describes an important lead and zinc producing region which is rapidly increasing in importance, and it is believed that this description of the geological occurrence and origin of these deposits will be of material assistance in its economic development.

Very respectfully,

C. W. HaYes,

Geologist in Charge of Geology.

Hon. Charles D. Walcott,

Director, United States Geological Survey. 



\title{
ZINC AND LEAD DEPOSITS OF NORTHERN ARKANSAS.
}

\author{
By George I. Adams,
}

\author{
Assisted by A. H. Purdue and E. F. Burchard.
}

\section{INTRODUCTION.}

Scope of this report.-The field work on which this report is based was carried on during the months of July, August, and September, 1902. The writer was assisted by Prof. A. H. Purdue, of the University of Arkansas, and Mr. Ernest F. Burchard. The larger portion of the time was used in the detailed examination and study of the Yellville quadrangle, which is between parallels $36^{\circ}$ and $36^{\circ} 30^{\prime}$ and meridians $92^{\circ} 30^{\prime}$ and $93^{\circ}$, and embraces Marion County, the northern border of Searcy County, the eastern border of Boone County, and the northeastern corner of Newton County. The adjacent country, which is usually recognized as mineral bearing, was examined in a general way. Mr. E. O. Ulrich was in the field two weeks collecting fossils and studying the rocks for the purpose of correlation, and Dr. George H. Girty devoted a week to a portion of the section in an adjacent area.

The stage of development of the field is such that the report is in a sense a preliminary one, as few of the ore bodies have been worked sufficiently to determine their extent. There are many openings and prospects and a few producing mines. The examination of the prospects consumed much of the time, and although the information obtained from them was valuable as indicating the position and manner of occurrence of the ore bodies, it was often unsatisfactory because the openings were of limited extent or had been made so long ago that they were covered with débris. Only a few of the mines which have underground workings were accessible, since most of them were idle and filled with water.

Historical sketch.-Lead ore was discovered in northern Arkansas by the early explorers and pioneers, and smelted by them in a crude manner, in order to obtain lead for rifle bullets. Schoolcraft, who passed through the region in 1818, mentions, in the account of his explorations, the occurrence of lead in northern Arkansas, and Featherstonhaugh in 1834 reported that a mine had been 
opened on Strawberry River. No attempt appears to have been made to produce lead in commercial quantities until in the fifties, when ore was smelted in the vicinity of Lead Hill. There was a revival of the industry in the seventies, but the cost of transportation was so great that the smelters, after operating for a year or two, were abandoned.

In early times zinc ores seem to have attracted no attention, as compared with lead ores, probably because they were not so well understood. A zinc smelter, however, was erected at Calamine, Sharp County, in 1857, but the company ceased operations at the outbreak of the civil war. In 1871-72 smelting was again attempted at this place, and was carried on for a short time. Prospecting for zinc ores began about 1886 . The ores are so generally distributed and so readily accessible that the region attracted the attention of mining men and investors, and in 1899 there was what might be called a rush into the field.

Limits of the northern Arkansas district.-The principal development of zinc and lead mining in northern Arkansas is in Boone, Marion, Baxter, Searcy, and Newton counties. The mines and prospects shown in Pl. I indicate in a general way the extent of the district. In addition there are some prospects to the west; and mining has been carried on at a few localities to the east, in Lawrence, Sharp, and Independence counties. The ores at these places are known to be similar to those of the area here described, but they are not discussed in this report.

Transportation facilities.-Until recently no railroad reached the field. Traveling was by means of stage. The route usually pursued was from Eureka Springs, a railroad point, eastward about 50 miles to Harrison, thence eastward 30 miles to Yellville; or from West Plains, Mo., a railroad station about 70 miles northeast of Yellville. The country is rough and the roads stony, so that traveling and transportation are difficult. Nevertheless, mining claims were developed and mills erected before the railroads had been extended into the field. It was thought that White River, which is navigable for small boats, would furnish an outlet for the ore, but the necessity of hauling and the uncertainty of sufficient water caused the abandonment of this route after a few shipments had been made. In 1901 the St. Louis and North Arkansas Railroad was built to Harrison from Eureka Springs, and since that time has been extended southeastward to Buffalo Fork of White River. It is proposed to further extend this road, by way of Marshall, southeastward in the direction of Little Rock.

The Missouri Pacific Railway has begun to build a line from Batesville, along the valley of White River, to Buffalo. From this point it will pass by way of Yellville, and thence northwestward into Missouri. This line will be in operation to Buffalo some time before the close of 1903 . 

PROFESSIONAL PAPER NO.24 PL.

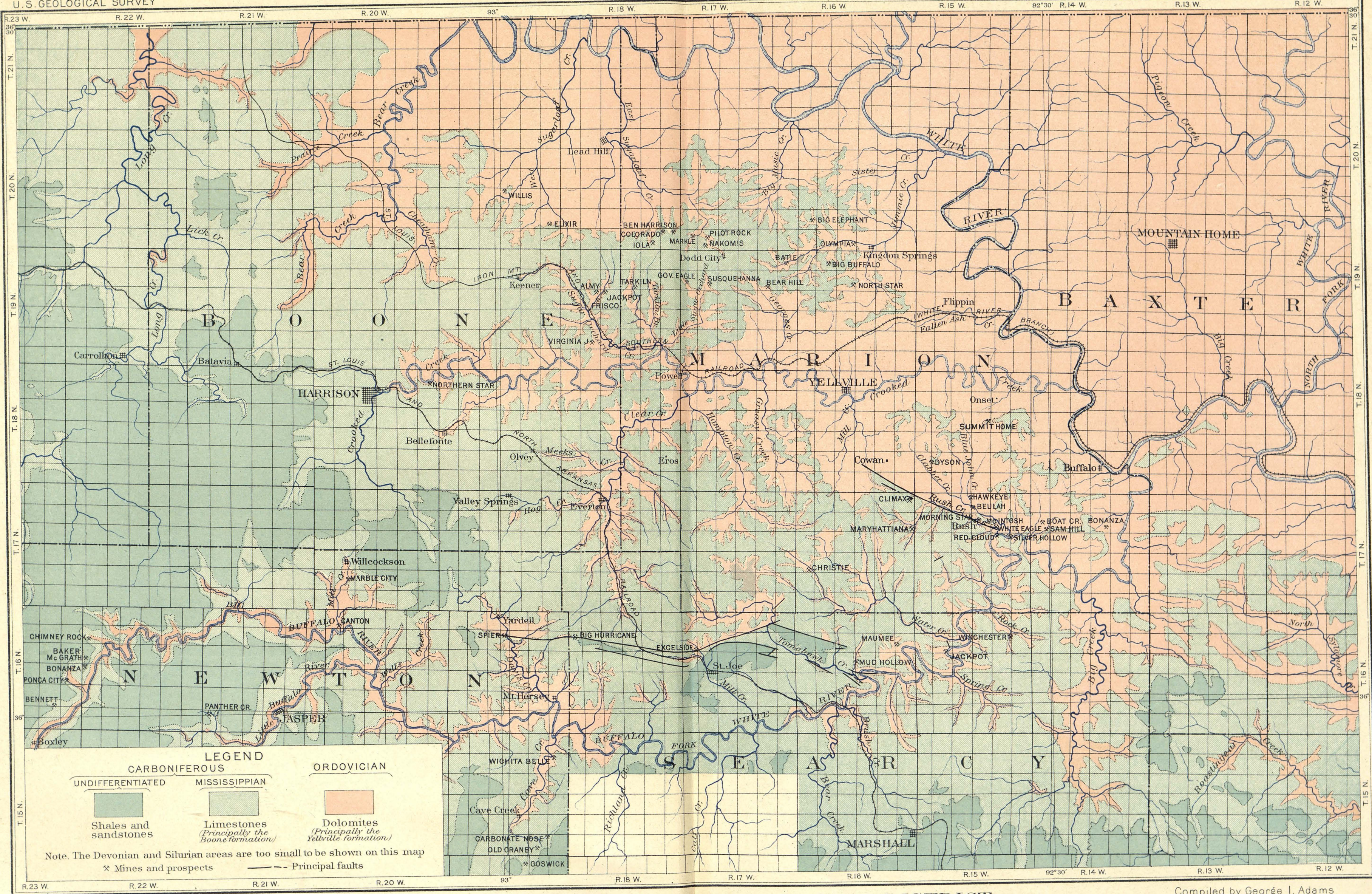

MAP OF NORTH ARKANSAS ZINC AND LEAD DISTRICT

SHOWING GENERAL, GEOLOGY AND PRINCIPAL MINES AND PROSPECT
Crompiled by Georse I. Adams
from detailed survey of the Yellville quadrangle and maps of
Arkansas Goological Survey

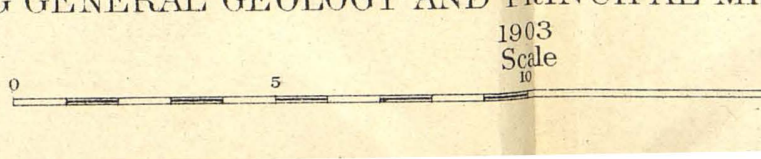



The completion of the railroads will afford facilities for shipping ore, so that mines - which have not been able to operate will probably begin work. Others, which had until recently attempted no development beyond prospecting for ore, are already erecting mills or more definitely determining the character of the ground preparatory to doing so. Although few of the mines are situated near the railroads, the distances which the ores must be hauled will be so lessened that the product can be marketed profitably. With the development of the mines railroad spurs and branch lines will probably be built, and the field can assume its true commercial importance.

Production of the district.-From the information contained in published reports and gathered by inquiry it has been estimated that the output of the northern Arkansas district up to and including the year 1900 was 1,500 tons of zinc ore and 500 tons of lead. In 1901 about 500 tons of zinc were marketed, and in 1902 about 1,000 tons, or double the amount of the previous year. The production of lead during 1901 and 1902 was unimportant. There is considerable ore now stored in the bins awaiting transportation facilities, and the production of the district promises to increase during the coming year.

Prospective development.-The question which is of most interest at the present time is, Will ore bodies in northern Arkansas warrant operations on a large scale? It is hoped that what is said in this paper will throw some light upon the question, which is a difficult one to answer in the absence of the extensive development of any of the mines. What has been done thus far in the way of mining is not a true criterion for the field. Some of the companies which have been organized have been promoted by men inexperienced in the production of zinc and lead. The expenditure of money in erecting mills and bringing in machinery, which it was necessary to haul a long distance, and the failure to market ore at a profit, because of the absence of transportation facilities, usually has been followed by the suspension of operations. Moreover, the ore deposits in northern Arkansas are not such as mining men generally are familiar with, and some have been misled by the results of their prospecting, since they judged that the ore bodies would continue similar to those of other fields. Finally, although certain of the mines have produced clean ores, the surface workings have usually resulted in the finding of mixed ores, which are difficult to market in a satisfactory manner. With the continuance of deeper workings and the following of ore bodies into the hillsides this difficulty is disappearing.

While it is impossible to predict with certainty the future of the field, there are certain of the mines now opened which are capable of a large output, and many of the prospects warrant further exploitation. 


\section{SURFACE FEATURES.}

General character.-Northern Arkansas is a hilly region, although to one who travels through it the amount of relief is not clearly apparent, since the timber nearly everywhere prevents a broad view. The streams have cut into the rocks so deeply that in their lower courses they may be appropriately considered as flowing through canyons. The walls of the canyons are usually steep on one side and have a gradual slope on the other. The main streams are tortuous, and the tributaries dissect the country into ridges having a dendritic arrangement. The best roads follow the divides or the stream valleys, and the roads which are divergent from them are usually so rough as to make heavy hauling impossible. Because of the broken nature of the country the soil forms a thin mantle over the rocks, except on the more level uplands or in the narrow alluvial valleys. The larger portion of the land is not suited for farming, because it is very stony, or becomes so soon after it has been cleared and cultivated. Agriculture is at present the principal industry, but its development will 'be limited by the nature of the land. Fruit raising, on the other hand, promises to be entered into more largely. The hillslopes are suitable for orchards, and the climate is particularly favorable.

Dissection of the country by streams has exposed considerable thicknesses of the rocks in such a way as to render the mineral contents of the upper horizons easily discoverable. The rough topography, however, is unfavorable to the building of numerous railroads and the hauling of the output of ore to shipping points. Every part of the country could be rendered accessible by the construction of wagon roads, as there is an abundance of good material for both roads and bridges.

Physiographic relations of the Ozark Plateau and Boston Mountains.-The zinc and lead mining district lies in what is known as the plateau portion of the Ozark region. This region embraces southern Missouri, the northeastern corner of Indian Territory, and northern Arkansas. Its drainage and topography are shown on the accompanying sketch map (Pl. II, $A$ ). The Ozark Plateau lies north of the Boston Mountains, which extend from Batesville, Ark., westward nearly to Muscogee, Ind. T. The northern border of the Boston Mountains presents an irregular escarpment, which is seen to the south of the zinc and lead fields. They are composed of a series of sandstones and shales, with some limestone beds, which erosion has cut into flat-topped spurs and peninsular-like ridges, between which are the stream valleys. The northern extremities of the ridges stand out as conspicuous points or promontories, from which may be obtained broad views of the plateau country. 

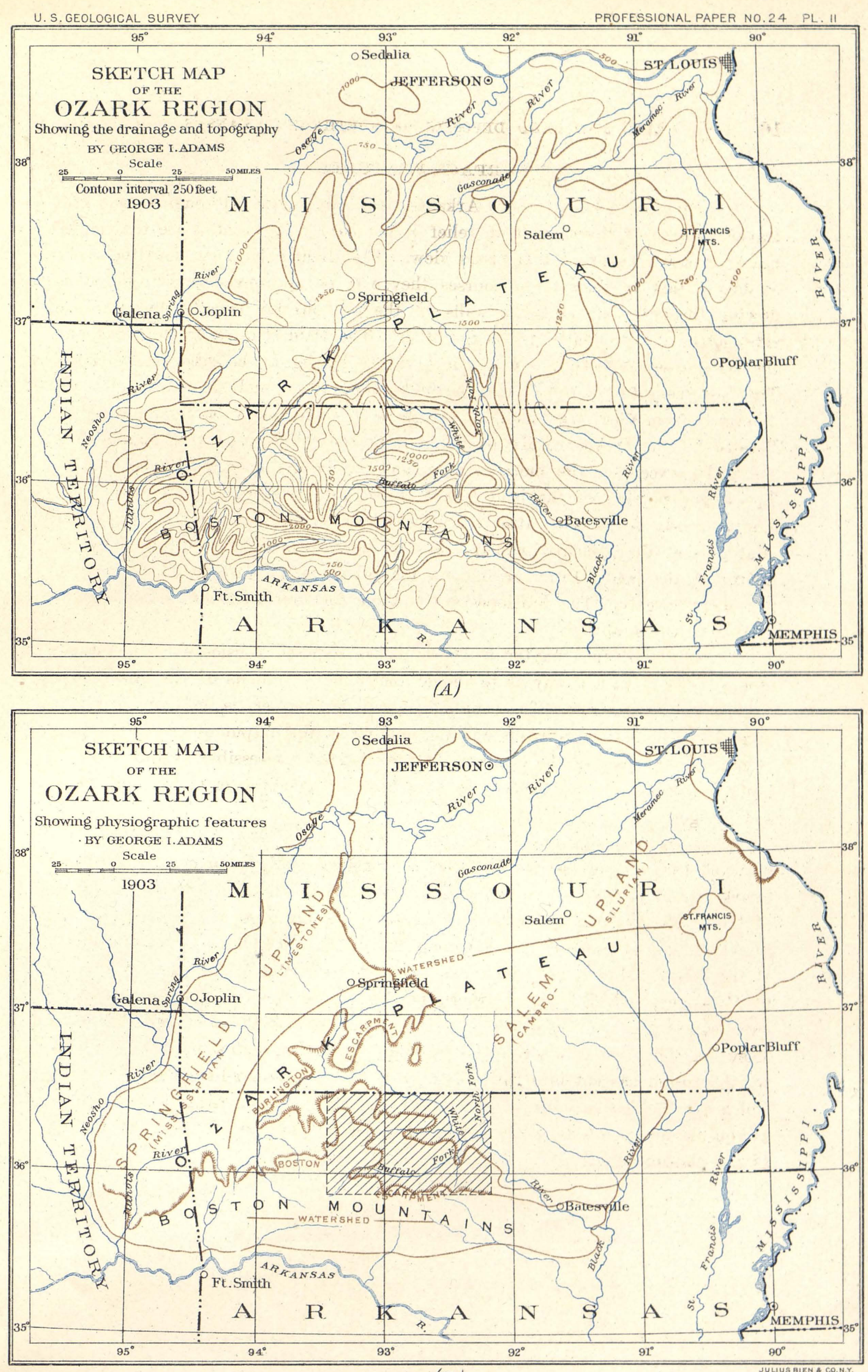

(B) 



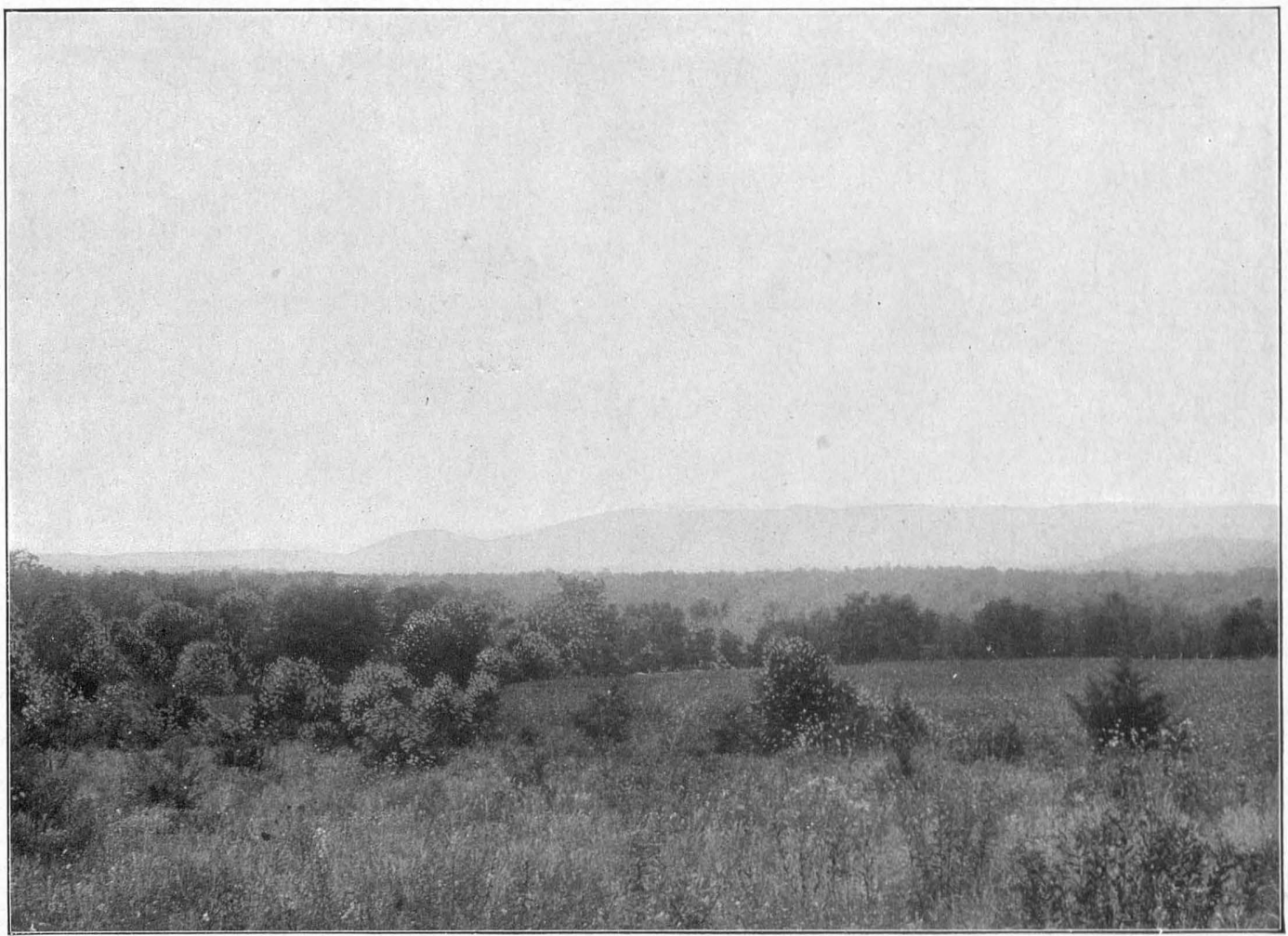

A. ESCARPMENT OF HALLS MOUNTAIN

Seen from the north, 5 miles distant, across Crooked Creek Valley,

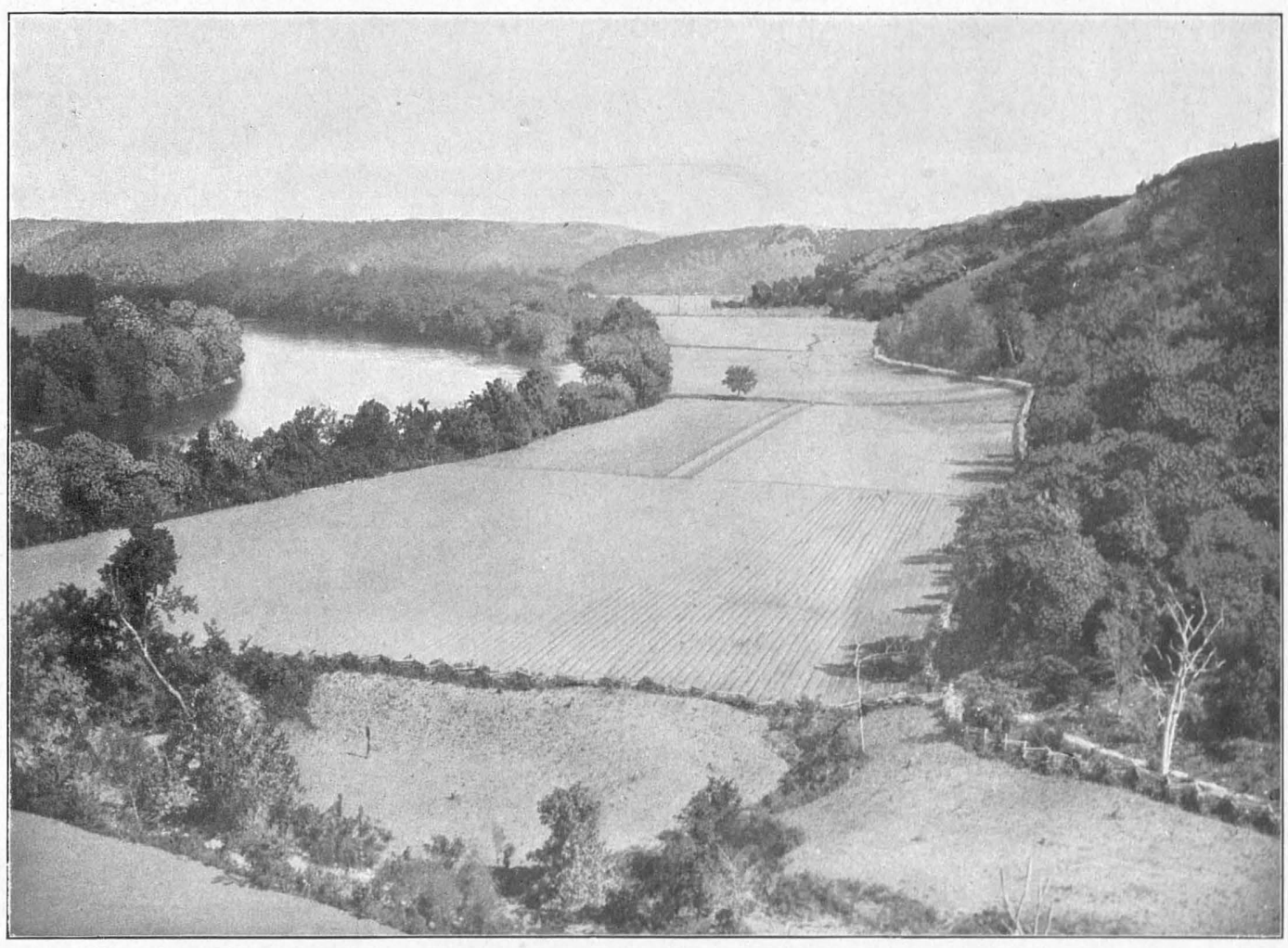

B. BOTTOM LAND ALONG WHITE RIVER NEAR GASVILLE. Looking northwest from mountain east of Denton's ferry. 

Divisions of the Ozark Plateau.-When seen in a broad view the irregularities of the plateau country are largely softened by the mantle of forest, and as the higher points rise to practically the same plane the plateau has a rolling or billowy appearance. There are, however, two divisions which are apparent in the landscape at. many points and are found to be related to the rock formations wherever the field is studied (Pl. $\amalg, B)$. Between them there is an abrupt change in elevation of about 300 feet, known as the Burlington escarpment. (See , Pl. III, A.) The higher region west of the escarpment is called the Springfield upland. It has its typical development in southwestern Missouri, around Springfield, from which place it was named. Its extension in northern Arkansas is a narrow, irregular upland lying at the foot of the Boston Mountains. The larger areas of its unbroken surface form the farm lands in what is known. as the chert country of northern Arkansas, and the rock which underlies it is the Boone limestone and chert. Its extent accordingly corresponds with the area of this formation shown on the accompanying map (Pl. I).

The Salem upland is developed upon the Yellville formation, which consists of dolomitic limestones, which form the country rock over the remaining portion of the plateau in northern Arkansas. It does not show its typical development in the mining district, however, since the valley of White River and the numerous tributaries of that stream give it a decidedly broken eharacter. In southcentral Missouri, around Salem, from which this division was named, it has a more even surface. However, the horizon line as viewed in northern Arkansas is found to be almost even, and it is readily seen that the higher points fall in the same general plane.

Lowlands.-Inasmuch as the two principal divisions have been discussed as uplands, it is natural to infer that lowlands exist, which are in contrast to them. This stage of physiographic development of the region is relatively recent. The streams have not had sufficient time to widen their valleys, and their work thus far has been confined to cutting them downward. Here and there, however, on the larger ones are found narrow, crescentic bottom lands, which occupy the inner side of the bends of the stream (Pl. III, $B$ ). What are now the uplands were in the previous period relatively low-lying plains, through. which the streams flowed in shallow valleys, and the canyons of the present time owe their tortuous courses to the sinuosities of the former drainage, which have been accentuated during the process of downcutting.

Previous surface features. - In discussing the geologic history of the zinc and lead district, it is necessary to reconstruct in a measure the conditions of the land surface which existed previous to the development of its present topography. 
An idea of what the country was probably like may be obtained by imagining the present valleys in the Salem upland filled to a level with the bluffs of the streams. If the upper courses of the streams were filled in a proportionate manner, the Burlington escarpment would still remain as a conspicuous feature, but the valleys within the Springfield upland would be less. sharply incised. What is now the Salem upland would be practically a lowland, and the Springfield upland would rise approximately 350 feet above it. The extent of the Springfield upland, however, would be somewhat greater than at present, and its border much less dissected, since in the process of the downcutting of the streams it has suffered extensive degradation.

It has been remarked concerning the northern Arkansas field that a large portion of the rocks which are mineral bearing have been carried away by the work of the streams. This undoubtedly is true, and an estimate of the amount may be formed by some such process of reasoning as has been outlined above. The ore-bearing rocks, however, which have been removed during the erosion of the stream valleys constituted but a small percentage of what still remain above the grade of White River, which has the deepest valley in this area. The slopes and hillsides which have resulted from the downcutting render the ores accessible and multiply many times the exposures of individual ore-bearing beds.

\section{DESCRIPTION OF GEOLOGIC FORMATIONS.}

The formations described in this report. have been mapped in detail within the limits of the Yellville quadrangle. Pls. IV and V, show the northern and southern parts of this area, respectively. On these maps the positions of the important mines and prospects are shown by crossed hammers.

Some of the formations are so thin that it is difficult to show them in their correct importance, but in the field they can be recognized if careful attention is given to the following descriptions of their character and thickness. For the purpose of setting forth the entire geologic section other localities have been visited and the relations of the formations studied and described.

\section{ORDOVICIAN SYSTEM.}

Yellville formation.-This name, Yellville formation, is applied to the magnesian limestones, or dolomites, of Ordovician age, which constitute the principal lead- and zinc-bearing rocks of northern Arkansas. They are of wide occurrence in the district, especially in Marion and Baxter counties. They are the oldest rocks exposed in northern Arkansas, and have been described in various preceding reports as belonging to the magnesian-limestone series. The base of the section is not exposed, and the total thickness can be estimated only from the record 



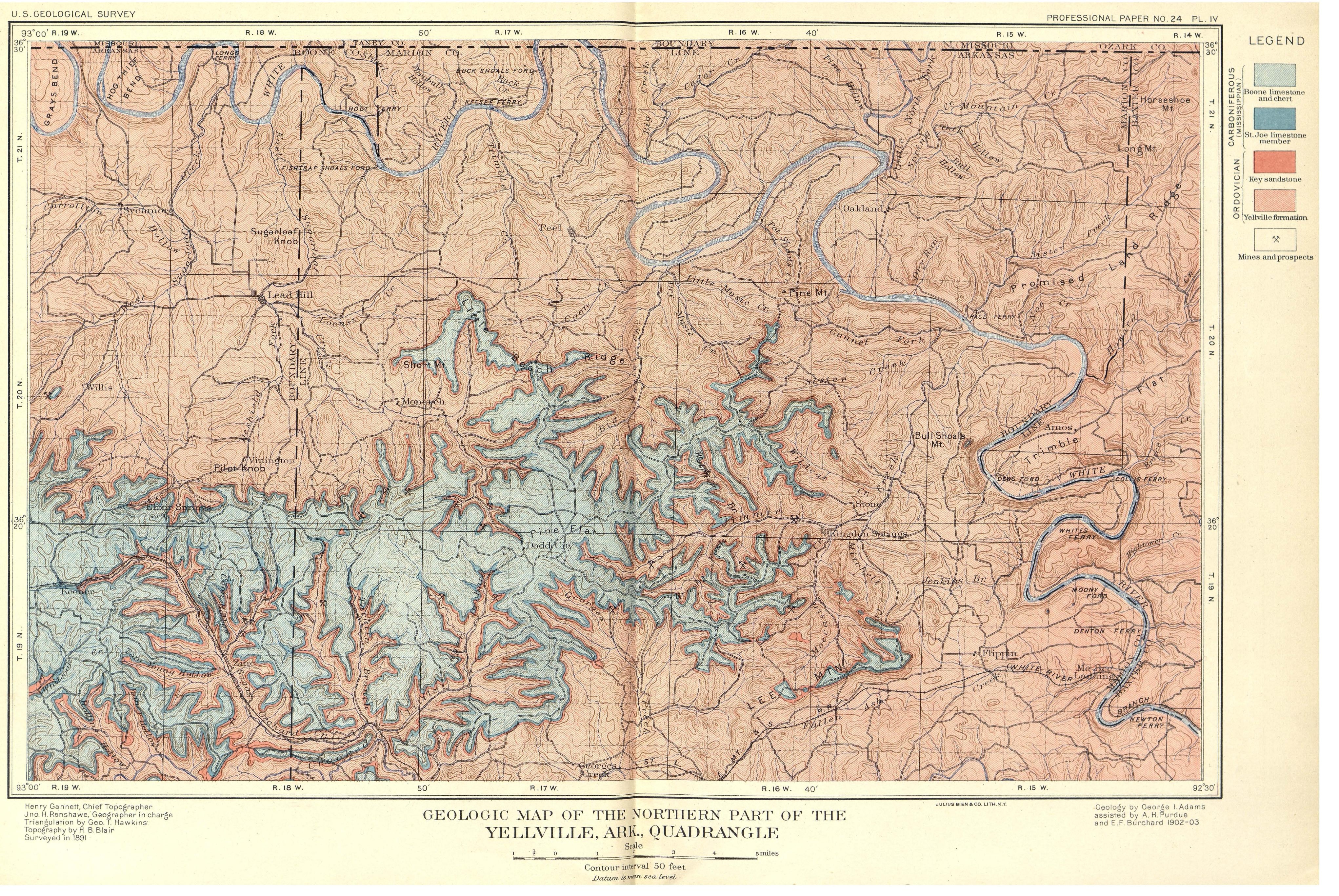



of a deep well which was drilled at Cushman, near Batesville, and which passed through 1,515 feet of strata without reaching the pre-Cambrian crystallines. The age of the rocks in the lower part of this well is not definitely known. Judging from the exposures around the base of the St. Francis Mountains in southeastern Missouri the rocks encountered in the well may range downward into the Cambrian. The Yellville formation is intended to include only such as are of Ordovician age. Along White River the natural exposures of the Yellville formation approximate 500 feet (Pl. VI, $A$ and $B$ ). The limestones vary from massive to thin-bedded strata, with intercalations of shaly material and well-defined shale beds. A section described in detail at any particular locality would probably not be found repeated in another part of the field, since the rocks vary in their lateral extent, the beds grading from one phase into another, according to the local conditions of sedimentation which prevailed at the time of their deposition. The rocks appear to have been laid down in relatively shallow seas, since mud cracks or sun cracks can be observed on exposed surfaces here and there, and the uneven bedding and change in texture indicate the action of currents, and apparently in some places the scouring of a sea bottom. The limestones, where they are not weathered, have a dense structure. Their color varies from gray to dark blue and chocolate brown. Their composition indicates that many of the beds are true dolomites, since they contain the accepted theoretical proportions of calcium carbonate and magnesium carbonate; but with the variation in lithology other constituents are found, such as clayey material similar to that of the shales into which they grade, and sand grains similar to the material which constitutes the saccharoidal sandstone which is described on a later page.

Where they present an argillaceous phase they exhibit laminations in which the thin films of clayey material indicate bedding planes. Not infrequently they are rich in organic matter, which gives them a dark appearance, and in some cases a decidedly fetid odor. The sandy phase of the dolomite locally manifests itself in the lower portion of the series, and in the higher portion there are some beds which have the character of sandstone. The clear, rounded grains of sand which are found distributed in some of the dolomites give them upon weathering somewhat the appearance of sandstones, since the calcareous material dissolves out. Where the exposures are unweathered the true nature of the rock is readily discernible. In other portions of the Ordovician sea, conditions were favorable to the extensive deposition of sandstones. Their local development in northern Arkansas recalls the so-called second, third, and fourth saccharoidal sandstones of the Missouri section as described by Swallow. One of these local beds of sandstone is exposed along the valley of Clear Creek. It occurs from 
50 to 75 feet below the top of the formation, and has a variable thickness, averaging about 20 feet. Throughout the remaining portion of the district it is impossible to identify this horizon. In the vicinity of Cowan post-office and in the country to the south for 2 or 3 miles there is a similar sandstone which is exposed at many places and gives rise to a sandy soil. Other beds were noted which are but a few feet in thickness and seem to have only a limited extent.

The bedding of the dolomites of the Yellville formation exhibits a peculiarity which may be described as sagging and thinning. It is apparently due to the unevenness of the floor on which the sediments were laid down and to the variation within short distances of thickness of the material deposited. As has been suggested above, current action may account for the phenomena to some degree; possibly, also, unequal settling and squeezing of the material took place before consolidation. This structure has the appearance of local unconformity in many cases, and is interestingly exhibited in the frequent nearly vertical exposures along the stream valleys.

The ore bodies contained in the dolomites are related to structures and secondary phases of the rock, which will be more fully described in another part of this paper, in connection with the question of ore deposition. They may be stated to be characterized by fracturing, jointing, brecciation, and faulting, which are the result of mechanical conditions and of solution, cementation, recrystallization, silicification, and replacement, which have been brought about by the circulation of ground water. Certain of the chemical changes have taken place so. extensively, and are manifested in the rocks independent of ore bodies, that they should appropriately be described here. The effect of solution has been to produce a cellular structure in certain of the beds, and these openings, as a result of subsequent deposition of silica, have the form of quartz druses. Not infrequently the dolomites, which contain a considerable amount of sand or have been largely replaced by silica, grade into a quartzitic phase. This seems to be more frequent in the lower portion of the section, and has been noted by the various geologists who have described the rocks as quartzites. The Yellville formation carries considerable quantities of chert, or flint, as it is sometimes called, which occurs as nodules and lenses. The chert of this formation may usually be 'distinguished by the fact that it has a white-and-black concentrically banded structure.

Key sandstone.-The Key sandstone, which is named from the post-office of Key, in the valley of White River, northeast of Fayetteville, is the rock most conspicuous and valuable to mining men as a datum in this district. It occurs usually as ledges or benches, and is locally known as the sand ledge or sand cap (Pl. VII, $B$ ). The rock is what is known as a saccharoidal sandstone, this name being applied because of the fact that when it is struck with a hammer it 



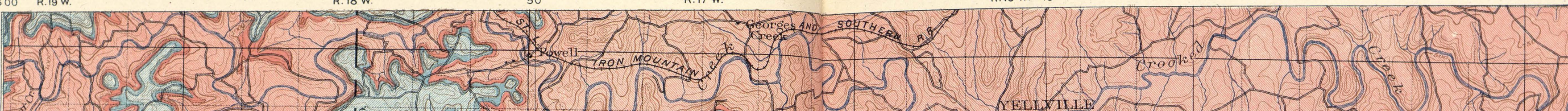

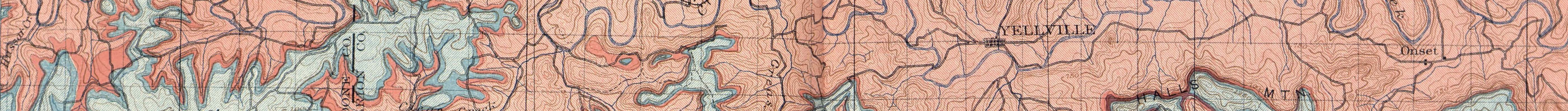

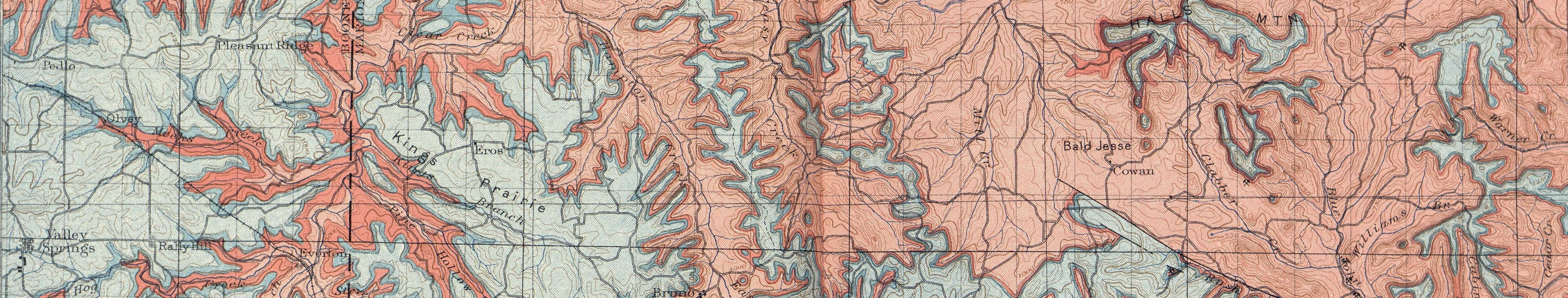

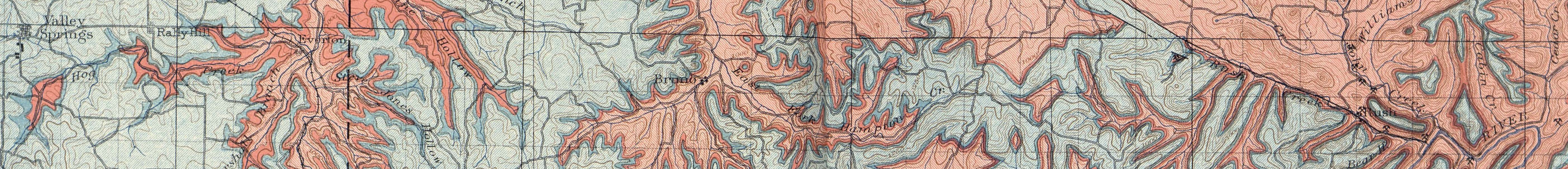
2.1.

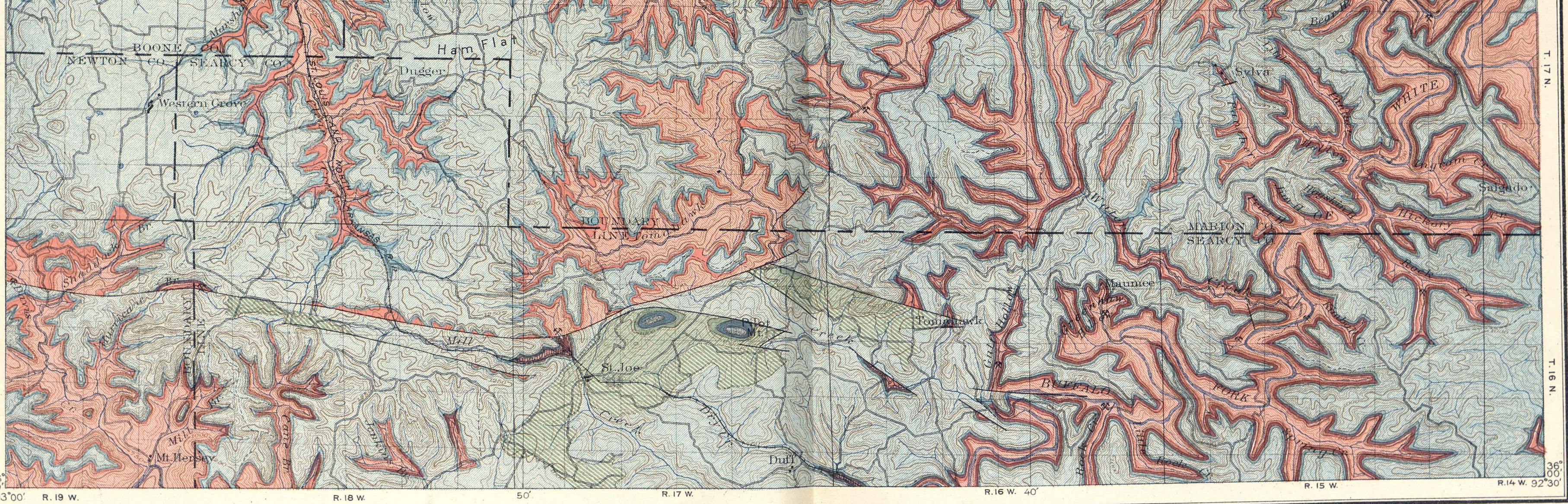



crumbles into a fine white sand, very similar in appearance to granulated sugar. The outer surface of the stone usually has a brownish appearance, as a result of the iron oxide which occurs as a coating upon it. When it is broken it exhibits a very even structure, the individual grains being of almost uniform size. Occasionally, where it is unweathered, small masses of pyrite occur in it, and it has a water-green color. When weathered the green color disappears and the pyrite is oxidized and transferred to the surface, forming a ferruginous coating. The ferruginous stain is also exhibited in the bedding planes.

The thickness of the strata varies from a few inches to several feet, and the character of the bedding is liable to change materially in a short distance. It not infrequently exhibits ripple marks and false bedding. Its weathered surfaces have a peculiar rounded appearance. The ledges are beveled, so that the layers have fluted edges. At the heads of ravines the sandstone not infrequently forms a waterfall, and the ledge is undermined in the process of erosion. Where it occurs along the canyon walls it is rendered conspicuous by the scantiness of the vegetation. On the hillsides it gives rise, upon weathering, to a sandy soil, and a few of the abandoned farms which are seen in this section of the country are located upon its outcrop. When the land is new and rich in humus which has accumulated under the protection of vegetation it is fertile; but after being cultivated for a few years the land washes badly, and the increased sandiness renders it poor farm land.

The conditions under which this sandstone was deposited appear to have been those of shallow water, in which the quartz sand was worn into more or less rounded grains. In the southern part of the district its marine origin is attested by the presence in it of a vertical structure known as Scolithus, which is due to the tubes formed by sea worms. Fucoidal markings are also found. The pitted appearance of the upper portion of the sandstone at many places is due to the occurrence of the scolithus, which causes it to weather unequally. The thickness of the sandstone varies from a few feet to over 100 feet, and is apparently due in part to conditions of deposition and in considerable measure to subsequent erosion.

The Key sandstone, because of its conspicuousness, is a convenient datum for determining the horizon at which the ore deposits occur. It is not an orebearing formation, although when ore bodies are found immediately below it they occasionally reach up into the lower portion of the sandstone.

Izard limestone.-The Izard limestone, which is named from Izard County, where it has its greatest thickness, extends into the southern portion of the zinc and lead district, and where present it immediately overlies the Key sandstone. Its greatest thickness reported is 240 feet, but in the area here described it 
seldom exceeds 100 feet, and thins down gradually on its extreme borders so that it can scarcely be found, and finally disappears from the section. This thinning is apparently due to the erosion of its upper surface. The rock is a bluish-gray limestone, having a very dense structure, and is difficult to break under the hammer or to work for building material, since it is what is called "plucky." The rock is seldom fossiliferous. The few indications of remains which have been seen in it are calcite casts, which appear as lines when it is broken. The base of this formation shows a tendency to grade into magnesian limestones and occasionally sandy beds. Although this formation can be identified readily by one who is familiar with it, where it is thin, as in the southern portion of the mining district, it is often unnoticed, since its weathered surfaces resemble the dolomites. In so far as has been observed it is not the seat of mineral deposits, and the few openings which have been made in it by prospectors give little encouragement for further work. Occasionally, however, where it is fractured it carries some pink spar, and it is not impossible that it is in some degree mineral bearing.

Polk Bayou limestone.-This formation, which when it is present in the field, occurs just above the Izard, differs materially from the rocks heretofore described. It has a coarsely crystalline structure and usually when freshly broken a slightly pinkish tinge. It consists of massive beds, and has a remarkably uniform texture throughout. The area of its occurrence in the Yellville quadrangle is very limited, its outcrop being confined to narrow exposures. in the southern part of the field. It does not occur as extensively as the Izard limestone, and its section is variable, seldom exceeding 15 feet. Its thinness in this area appears to be the result of the erosion of its upper surfaces. It is typically represented in Independence County, north of Batesville, on Polk Bayou, from which locality it is named.

Its presence in the field here described is significant in the geologic history of the area, but it has no importance as a mineral-bearing rock. Because of its uniformly crystalline structure it has been described as a marble in the Arkansas State reports. It has some value for building purposes, but thus far is not used commercially.

DEVONIAN SYSTEM.

Sylamore formation.-The Sylamore formation consists principally of a sandstone bed, and was named from a creek in Stone County, where it is well exposed and has a maximum thickness of 40 feet. It has associated with it a bed of shale. The relation of the sandstone to the shale has not been definitely stated in previous reports. Wherever the formation has been found in the 


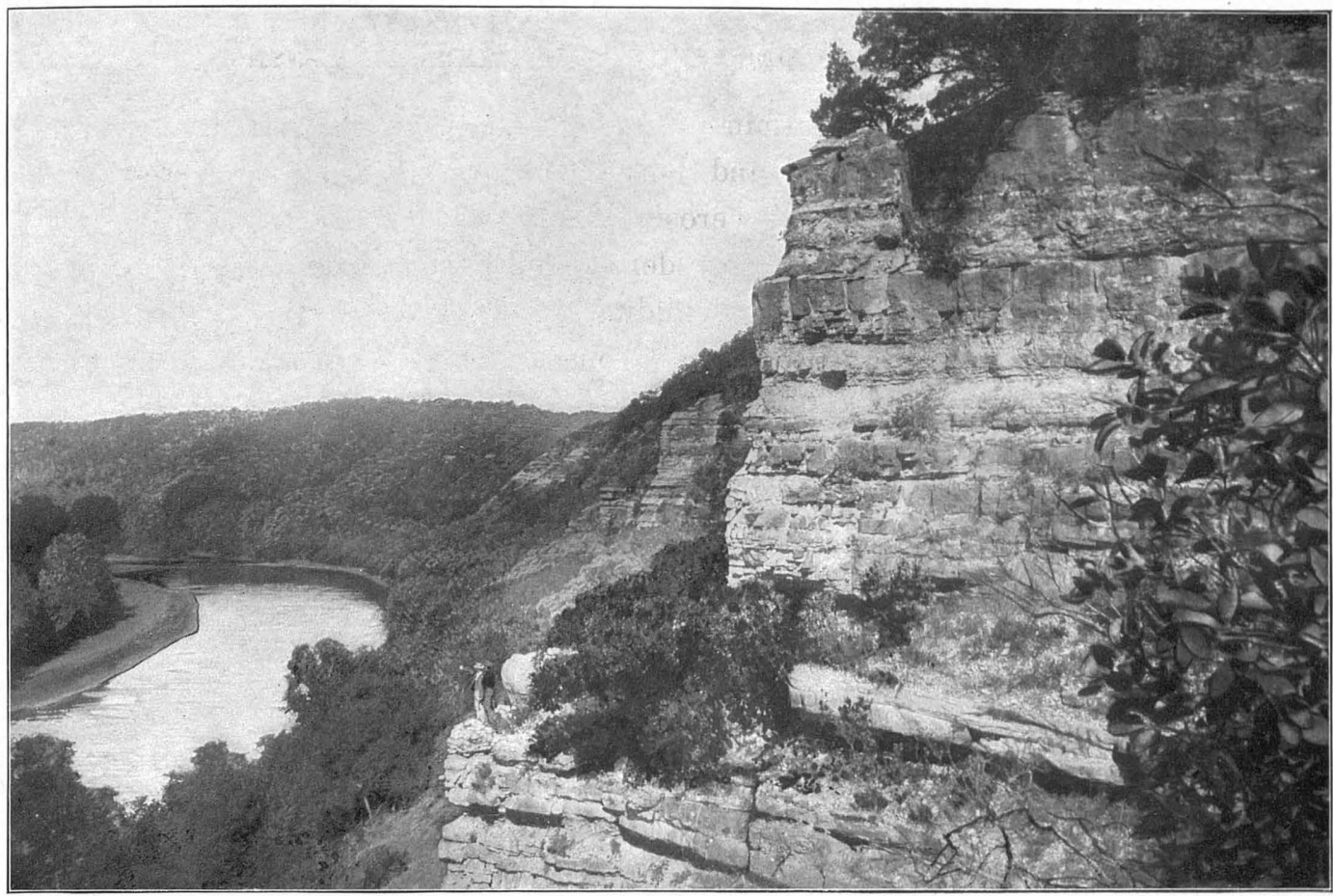

A. RICHMOND BLUFF, NEAR AMOS POST-OFFICE, IN BAXTER COUNTY, ARK.

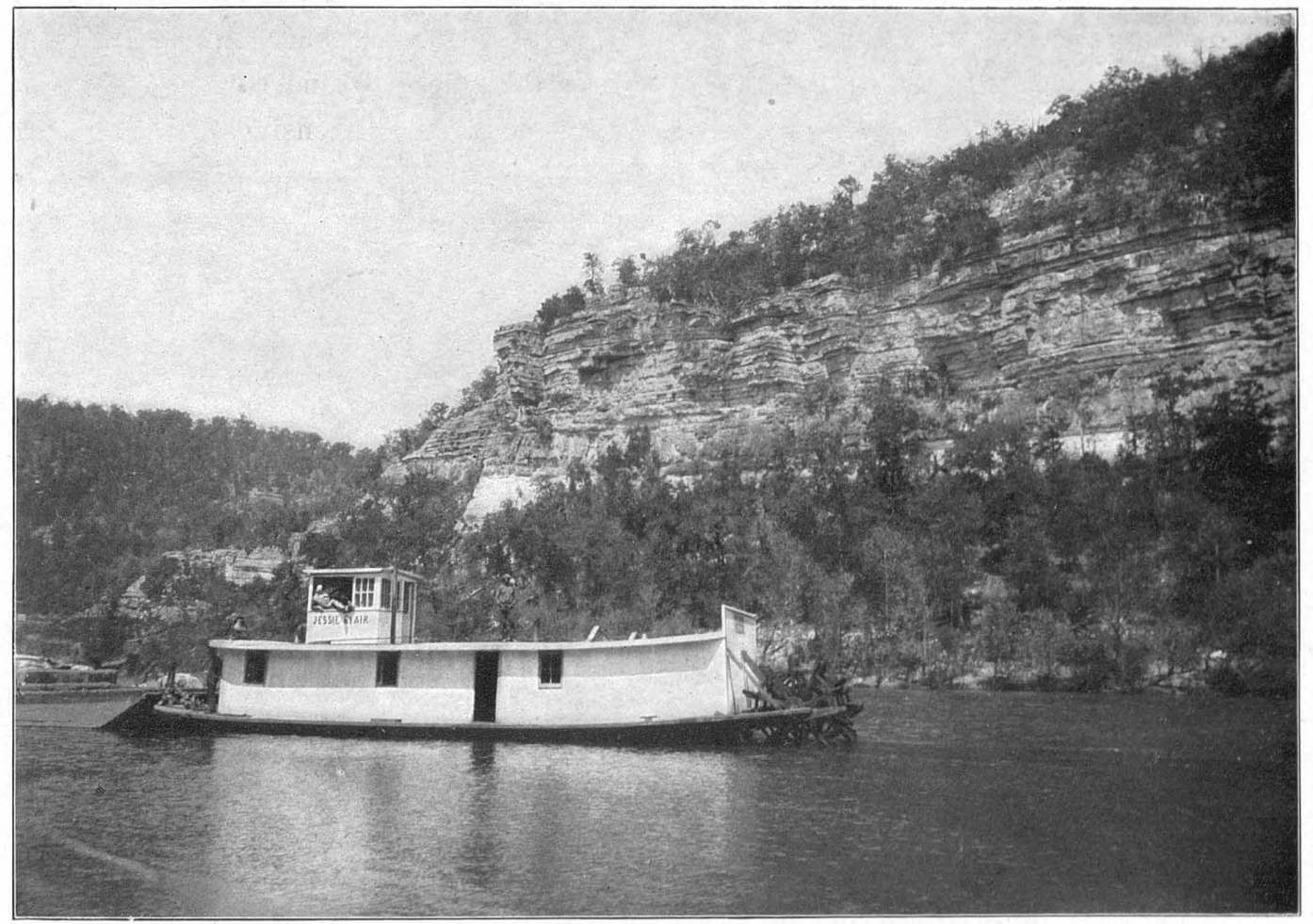

$B$ ENGLES BLUFF, NEAR SYLAMORE, IN IZARD COUNTY, ARK. 

Yellville quadrangle, the sandstone lies above the shale. Its maximum thickness is about 7 feet, and the shale below it does not exceed 15 feet.

The sandstone consists of rather coarse quartz grains, which have been rounded, and, except for the size of the grains, the rock resembles the saccharoidal sandstone in a general way. The Sylamore sandstone thins so that in some places it is not represented and in others occurs only as variable, lens-like masses or sandy beds in the upper part of the shale. The shales, where they are thickest, as at the exposure on Dry Creek, below Duff, are rather uniform in character and have a greenish oolor. Where the sandstones and shales are variable, as is the case just north of St. Joe, the color is darker, often nearly black, and the formation contains a notable amount of phosphate pebbles, which are frequently embedded in a sandy matrix, giving the rock a conglomeratic appearance. The pebbles are sparingly represented at other exposures, but the phosphatic material seems to be more abundant where uneven bedding and variable conditions of sedimentation have occurred. The phosphate pebbles when unweathered are black, but on exposed surfaces they are yellowish or brownish. They vary in size from very small ones up to the size of walnuts, or even larger. They have a waterworn appearance.

The relation of the Sylamore sandstone to the lower rocks is plainly exhibited in the bed of the stream southeast of Duff. The Sylamore there rests upon the Polk Bayou limestone, and the surface of the limestone has been exposed by erosion so that the irregularities of its surface, which were produced prior to the deposition of the Sylamore shale, can be seen in the creek bed. It is potholed and pitted and worn into channels. In these depressions remnants of the shale and the contained pebbles may be seen. Thus far, at all the outcrops of the Sylamore which have been visited it rests upon the Polk Bayou limestone. It has a more limited geographic extent than that formation, and the sedimentary basin in which it was deposited appears not to have extended west of the Yellville quadraingle.

The age of this formation has been in dispute. Fragments of large fish bones have been found embedded in the sandstone, and these are considered as indications of Devonian age. Aside from these remains some invertebrate fossils occur, which tend to corroborate this view. The confusion which has previously existed in the attempts made to classify the Sylamore formation has arisen from the fact that an effort has been made to correlate it with the Noel shale (described as the Eureka shale in the Arkansas reports), which occurs farther west. There is, however, an intermediate region, approximately 30 miles in width, in which neither of these formations is represented. The reason for associating the Sylamore formation 
with the Noel shale seems to have been that they are both succeeded by the St. Joe member of the Boone and the shales are somewhat similar.

Although the phosphatic pebbles of the Sylamore are locally sparingly represented in the lower few inches of the St. Joe member of the Boone, there was a break in sedimentation between the formations, and the pebbles have found their way into the St. Joe as a result of the reworking of the lower beds. In the case of the Noel shale there is a gradual transition from the shales to the limestones, and an interlarding of the shales in the lower beds of the St. Joe at some localities in such a way as to intimately connect them:

It is a surprising fact that Devonian sediments should be so sparingly represented in this region. During the Devonian interval the older rocks were .largely subject to erosion. It was at this time that the beveling of the Polk Bayou, Izard, and Key formations took pláce. Probably the Yellville formation also suffered considerable thinning at some localities. The Sylamore formation may be a remnant of thicker deposits which accumulated during the Devonian period, but more likely it represents a marginal deposit in an encroaching sea. The fact that it contains phosphatic material and sandstones composed of rounded quartz grains is favorable to the latter theory. The shale probably represents the mud, and the pebbles the estuarial accumulations of phosphatic nodules which were deposited in some such way as were the pebble phosphates of the Charleston phosphate region, in South Carolina, where the phosphate is obtained by dredging in the mouths of rivers.

\section{CARBONIFEROUS SYSTEM.}

MISSISSIPPIAN SERIES.

Noel shale.-The Noel shale has been previously described by the Arkansas State survey under the name of "Eureka shale;" but this name is preoccupied by the Eureka quartzite of Nevada, and accordingly it has been renamed, from the town of Noel, in southeastern Missouri, where it has been studied and at which place it is typically exposed. It consists of a bed varying from a few feet, and in some cases a few inches, up to 70 feet in thickness. Usually it averages from 15. to 30 feet. Its color is often black, although not infrequently it has a greenish, and sometimes a yellowish, appearance, according to the condition of weathering or the amount of carbonaceous material contained in it. Thus far it has never been found lying on the Polk Bayou limestone, as does the Sylamore. It commonly rests on the Key sandstone, or in case that formation is absent, as a result of pre-Carboniferous erosion, it rests on the Yellville formation. In its upper part it contains at some places thin, limy layers, and when not abruptly succeeded by the even-bedded St. Joe member' of the Boone formation, it grades upward into that formation, thin layers of shale being found 


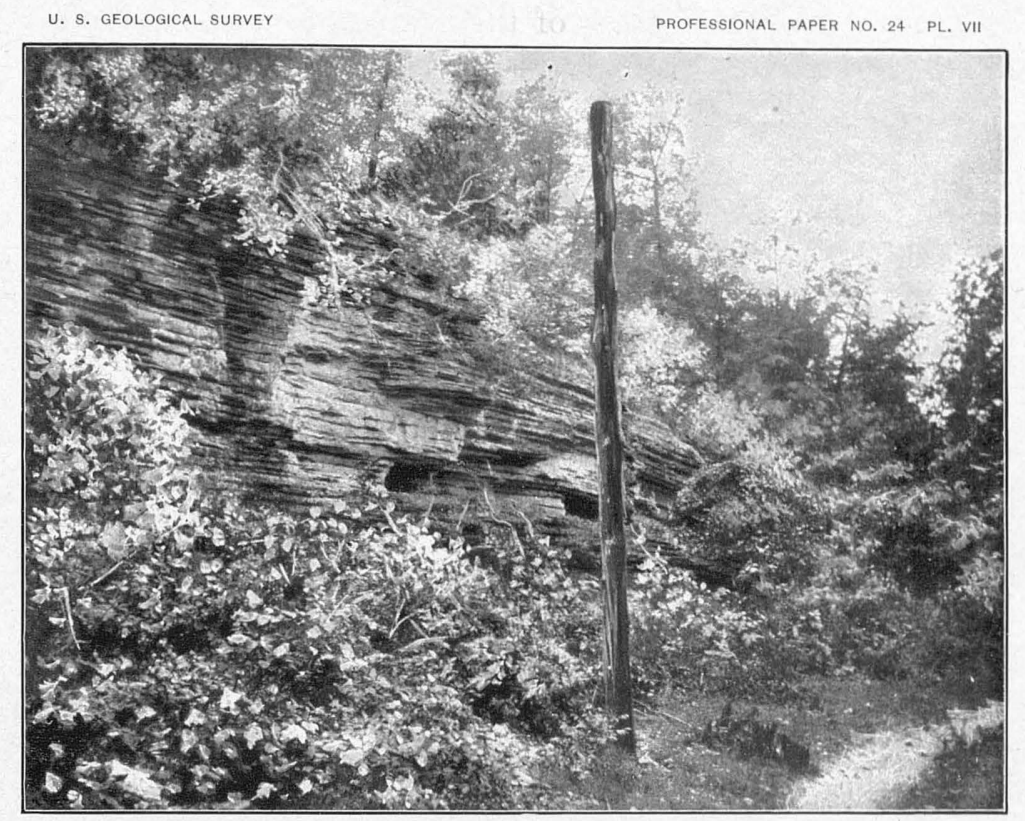

A. LEDGE OF ST. JOE LIMESTONE.

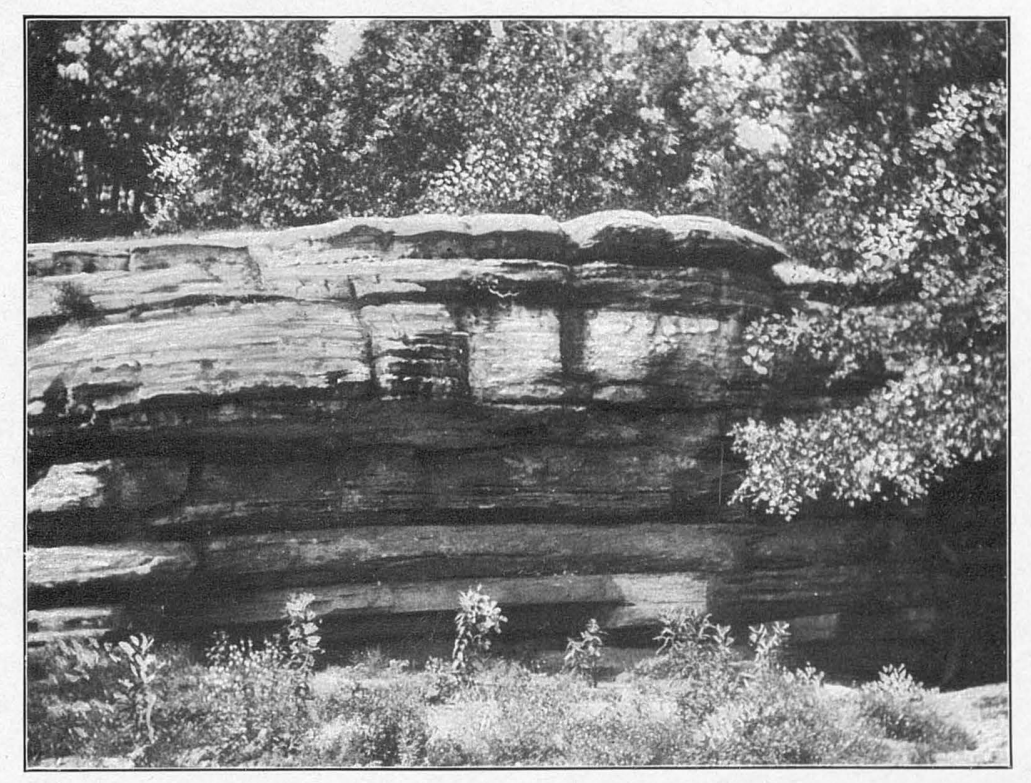

B. LEDGE OF KEY SANDSTONE. 

between the beds of limestone. The Eureka shale is not known to carry phosphatic material, nor has it thus far yielded bones of fishes. The areas in which it outcrops are to the west of the zinc and lead district and are widely separated from the Sylamore, and there appears to be no reason for any longer confusing it with the Devonian. The fossils which it has yielded are of Carboniferous age, and it probably represents the muddy sediments deposited in the encroaching Carboniferous sea.

Boone limestone and chert. - The Noel shale is succeeded by the Boone formation, which appears to be conformable with it, and represents merely a change in the character of sedimentation. Over a large area its basal member is an evenbedded limestone, free from éhert and showing in a distinct ledge (Pl. VII, $A$ ), sometimes shelly and thin bedded. It is known as the St. Joe limestone member. Its thickness in northern Arkansas varies from a few feet up to 50 feet. At some places it is difficult to distinguish, because of variation in character and its resemblance to the overlying rocks. It has been thought to be absent at certain localities in the Yellville quadrangle, but careful search has resulted in finding it at these places. Its upper beds are often full of crinoid stems, and, although it contains other fossils, they are not abundant. It is usually of a soft-gray color, and when freshly quarried often has a bluish cast. In the zinc and lead district, particularly at St. Joe, from which locality this member is named, it has a reddish appearance and a chocolate-brown color on fresh surfaces. The red color is due to the presence of iron. Where water has circulated through the beds the rock has a variegated appearance, being changed to a greenish color. Within the field here discussed it has been noted that sometimes a portion of the ledge is red and the remaining portion grayish. The area within which the red color prevails is to the south, around St. Joe. This rock has been described as a marble by the Arkansas State survey. It will take a good polish, but it is questionable whether it will ever be of economic importance as an ornamental stone, since it does not occur in suitable size. The rock is often favorably exposed for quarrying. Where it is underlain by a shale the weathering of the soft material causes the ledge to jut out and eventually to break down into large slabs and blocks. Upon weathering it sometimes forms isolated columns. Usually the abundance of chert from the overlying portion of the Boone formation disguises its outcrop.

The remaining portion of the Boone formation consists of beds of cherty limestone and beds of chert, which vary in their lateral and vertical extent in such a way that it has been impossible to divide this part of the formation into members which can be generally recognized. The thickness of the formation is about 325 feet. The country in which the Boone formation occurs is distinguished 
frequently massive, and give rise to an escarpment, a bench being developed on its upper surface. This formation is regarded as the highest one of the Mississippian series. It is probable that the thinning to the north and west is due to shore conditions, and its absence in some cases may be due to erosion previous to the deposition of the Pennsylvanian series which succeeds it. It is named from the post-office of Pitkin, in Washington County, south of Fayetteville. The exposures in that vicinity have been well described and noted in reports by the Arkansas survey. In the Yellville quadrangle it is found near the upper part of the two mountains, $1 \frac{1}{2}$ and 2 miles northeast of St. Joe. The formation there is about 90 feet thick.

\section{PENNSYLVANIAN SERIES.}

Morrow formation. - Under this name is described a variable formation, consisting of shales, in which are some thin limestones and occasional sandstone beds. The basal portion is usually a sandstone or a sandy shale. Above this there is the limestone which has been called the Pentremital limestone by the Arkansas survey. Inasmuch as this is not a geographic term, the name "Brentwood" is applied to it in this report. The limestone sometimes occurs in a single ledge, but is often separated into two ledges, between which shales and sandstones intervene. The stratification is variable, and because of the absence of the limestone at some localities it may be considered as a lens within the Morrow formation. The third member of the formation has usually been designated the coal-bearing shale. In the vicinity of Fayetteville, where it has been more particularly studied, a bed of coal is found in this shale at a number of places along the northern border of the Boston Mountains. It is seldom thick enough to be mined profitably, but has been opened and is used locally, particularly in Washington County, where it is about 14 inches in thickness. Within the area discusséd in this report coal is said to have been found in Gaither Mountain, but it is not of any importance. Some evidence of prospecting for it was seen on the slopes of Boat Mountain, but no information in regard to its character at that place was obtainable.

Not infrequently there is a stratum of limestone above the coal-bearing shale which forms a variable lens, and in the vicinity of Fayetteville it has been described as the Kessler limestone. It is seldom more than 5 feet thick, although it reaches a thickness of 20 feet, and its presence in the slope is usually shown by thin slabs a short distance below its point of outcrop. Above it there are a few feet of shales and thin sandstones which belong in the Morrow formation. The upper limit of them is rather indefinite, but at many places is marked by the presence of heavy sandstones which carry quartz pebbles. 
Winstow formation.-This name, which is taken from the town of Winslow, south of Fayetteville, in the Boston Mountains, is here applied to rocks which have usually been designated by the term Millstone grit. The base of the formation is at most localities characterized by the presence of quartz pebbles. The formation attains a great thickness in the Boston Mountains, and its upper limit has not yet been definitely placed. As compared with the Morrow formation below it, it contains much more sandstone, and the beds are often massive and exposed in heavy ledges, which give rise to escarpments. No persistent limestone beds have thus far been found in the Winslow, and the sandstones have not yielded fossils, although no doubt they contain them at some places. There are shale beds in the upper part of the formation, but in the southern border of the lead and zinc field only the basal portion is represented, and within the Yellville quadrangle it is found only on the top of the two small points about 2 miles northeast of St. Joe.

GROUPING OF THE ROCKS WITH RESPECT TO ORE DEPOSITS.

Nearly all the ore deposits occur in either the Boone or Yellville formations. They are more important and more widely distributed in the Yellville formation, which occurs principally in the northeastern part of the district, and is the lower of the two. The Boone formation is ore bearing at a few places in the northern part of the field, but most of the mining developments in it are in the southwestern portion. Between these two ore-bearing formations there intervene some thin ones (the Izard, Polk Bayou, Key, Sylamore, and the St. Joe member), which are represented on the detailed geologic maps of the northern and southern parts of the Yellville quadrangle (Pls. II and III). They seldom carry any ore, and are grouped with the other rocks on the general map of the district (Pl. I), since they outcrop in narrow bands, which can not be shown on a small scale. The Key sandstone is an easily recognized formation, and is useful in the field for determining the division line between the upper and lower ore-bearing rocks. Many of the mines in the Yellville formation are at horizons a short distance below the Key sandstone. The undifferentiated Carboniferous shales and sandstones shown on Pl. I are above the Boone formation. They are not ore bearing, and limit the field to the south and west. They include the Batesville, Fayetteville, Pitkin, Morrow, and Winslow formations.

\section{HISTORY OF PHYSICAL CHANGES.}

Sedimentation.-In northern Arkansas, as will be gathered from the foregoing discussion, the formations are all of sedimentary origin. The nearest igneous rocks are in the St. Françis Mountains, in southern Missouri; in Camden County. 
forms of the land surface have not been wholly obliterated (fig. 1). The rocks which have been removed were the northern extension of the undifferentiated Carboniferous shales and sandstones, the Mississippian limestones where they are not now represented, and a considerable mass of the lower rocks in the area in which the Ordovician chiefly occurs. The history of the region indicates that in Tertiary time a plain was developed which coincided largely with the upper surface of the Boone formation or the Mississippian limestone. At that time the lower rocks were not so widely uncovered, and the shales and sandstones formed mountains and isolated areas to the north of the present escarpment of the Boston Mountains. This stage was a transitory one, and the downcutting of the streams and the further wearing away of the land surface have brought about the present features of relief, and exposed the rocks as they are found at the surface to-day.

The local changes in the rocks which remain may be attributed to the circulation of ground water. The modifications of the circulation of the ground water which have taken place from time to time and the conditions which influence the circulation will be described later in this report,

Deformation.-No extensive disturbances occurred in the district to change the rocks from their original nearly horizontal position. The area has suffered numerous oscillations, but it has always been remote from the principal effect of the forces. The unconformities mark the changes in the attitude of the rocks with respect to sea level from time to time; but during later periods, especially after the close of sedimentation, the record of physical changes can be inferred only from the surface features.

Within the rocks themselves two principal classes of structure are seen. These may be attributed to movements in the vertical plane which have produced fractures and faults, and to movements in the horizontal plane which have given rise to breccias. Locally, there are exhibited minor flexings' of the structure, as is shown by occasional well-marked dips; but no definite system of folds can be made out. The structure may be spoken of as undulating, giving rise to local domes and 
basins or shallow synclines and low anticlines, the axes of which are not clearly discernible. The rocks apparently have suffered considerable deformation as a result of compressive forces. This has given rise to occasional fracture zones; but a second, and perhaps more important, result was brecciation of the beds. This was produced by the differential movement of the strata, and is particularly exhibited in the rocks of the Yellville formation (Pl. VIII, $B$ ). The variation in the structure of these dolomites, which are in places massively bedded, and in other places thin bedded, laminated, and even shaly, resulted from the lateral movement being taken up in varying degree by the individual beds, so that the motion due to compression was such as is produced by forces acting in couples (fig. 2). The brecciation is due to the tendency of the pieces resulting from the

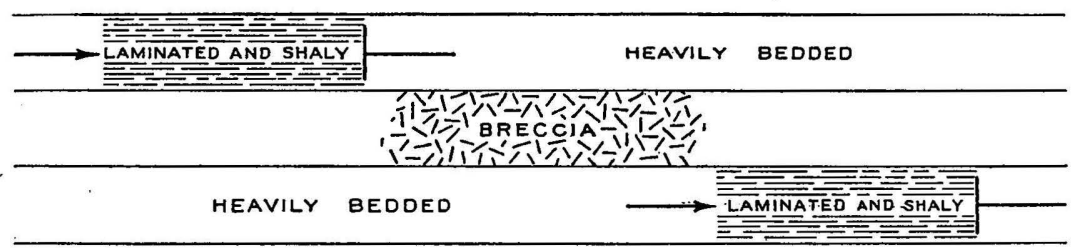

FIG. 2.-Diagram to show how stress may produce differential movement and brecciation as a result of variation in the character of the rocks acted upon.

breaking of certain brittle strata to shear past each other, or to rotate with the horizontal movements of the adjacent beds, so that the fragments are relatively displaced.

In the Boone formation compression produced principally fracturing and fissuring. The walls of the fissures not infrequently exhibit slickensiding, which has been produced by the rocks moving past each other horizontally.

The faults of the district are, with few exceptions, normal faults. All the more important ones thus far studied belong in this class. It is probable that some thrusting occurred at the time of compression, but no extensive thrust faults have thus far been found, though local ones are seen in certain exposures and in the workings of some of the mines. The normal faulting is believed to be of later date than the brecciation of the horizontal beds. In certain places the faulting has given rise to fault breccias, which are very similar in character to the bedded breccias, but are developed in a vertical rather than a horizontal plane.

Origin of the structure.-The fracturing and brecciation above mentioned are probably due to stresses induced at the time of the folding in the Ouachita 4538-No. $24-04-3$ 
Mountain and Arkansas Valley regions (fig. 3). At the close of the Carboniferous

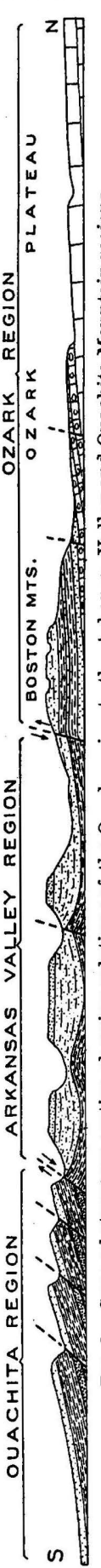
period the thick mass of sediments which bad accumulated in what is now central Arkansas and western Indian Territory was folded in a manner which suggests that it was thrust to the north. There are close folding and thrust faulting in the Ouachita Mountains and open folds in the Arkansas Valley region. In the southern border of the Ozark region, and particularly in the area under discussion, the generally hortizontal position of the rocks was retained, but there was considerable movement of individual beds. This movement was one of accommodation, and resulted in fracturing, without marked displacement. It took place largely along the bedding planes, and resulted in brecciation of the beds. The normal faulting in this area is of later date, and is probably due to the readjustment following the crushing, or to subsequent oscillations of level.

Geologic conditions influencing circulation of ground water.-The rocks which constitute the Ordovician system and the Mississippian limestones of the northern Arkansas district may be considered as relatively permeable. In the Ordovician are local beds of shale, through which water would not readily pass, and the Devonian rocks, which have a very limited extent in the southern part of the field, are of about the same character and importance in controlling the path of the ground water. They do not have a wide influence, since they do not form persistent horizons. Where they occur they probably diverted the solution laterally, but no localization of ore deposits seems to be directly due to them.

The shales lying above the Mississippian limestone, on the contrary, have sufficient thickness to make them an important factor in determining the movement of ground water. Formerly they extended from their present boundary near the base of the Boston Mountains northward into Missouri, and covered a considerable part of the Ozark region. Before they were removed they acted as a confining or limiting horizon. Water entering the Ordovician dolomites and Mississippian limestones where they outcrop, and moving with the dip as it passed southward, was under a hydrostatic pressure beneath these shales. There may have been a first concentration of the ores, due to this circulation, and, if so, it could have taken place from the upper portion of the Mississippian limestones, which were below these shales, to the bottom of the Ordovician. This reasoning may be appealed to in accounting for the ore bodies now found in the Mississippian limestones near the base of the Boston Mountains, where these rocks have recently been uncovered by erosion. It is possible, however, that the concentration was caused by lateral circulation 


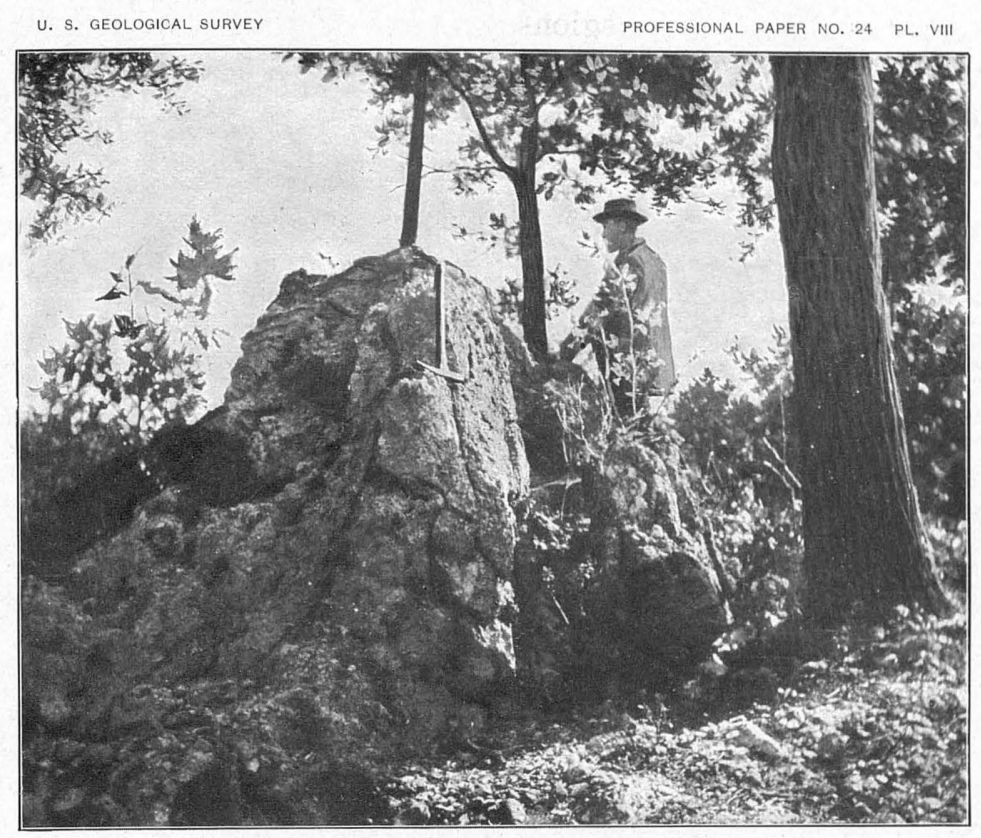

A. MASS OF SILICIFIED BRECCIA MARKING THE ST. JOE FAULT, NEAR THE EXCELSIOR MINE.

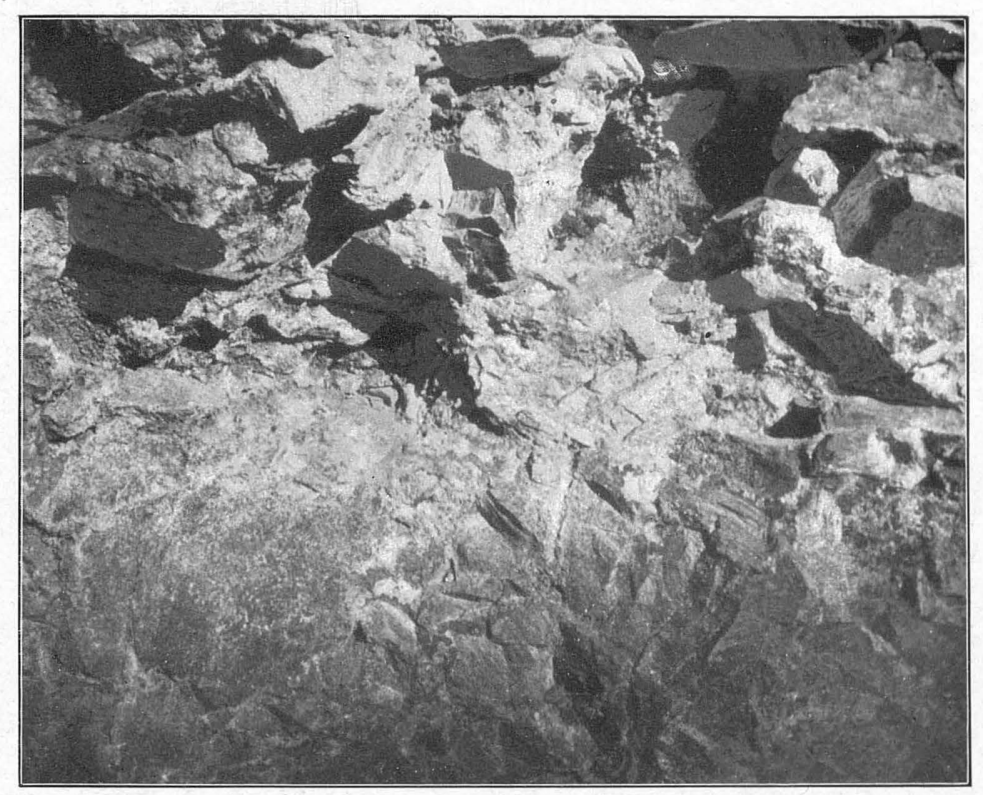

B. NEAR VIEW OF DOLOMITE BRECCIA CEMENTED WITH PINK SPAR. 

adjacent to the fractures in which the ore bodies are found, and not by factors which are of such wide influence.

As erosion progressed the shales and other formations lying above the Mississippian limestone were speedily removed from the more central portion of the Ozark region, so that the conditions which at first existed, as above outlined, were not long maintained. The main streams of the region, such as White River and its tributaries, soon cut through these formations, so that water which may have formerly been under hydrostatic pressure found issuance in their valleys. For a long period there have been no upper confining shales in the northern part of the field. The surface water has been free to descend into the Mississippian limestones and Ordovician rocks, or through the Mississippian limestones into the Ordovician, and the point of issuance of such portions as have reappeared in the surface flow has been in the valleys of the larger streams. There no doubt has been lateral movement alóng bedding planes, through the more permeable strata and open and brecciated beds, and along the surfaces of local shale beds. The saccharoidal Key sandstone, which is a conspicuous formation and one which is relatively porous, has probably been a horizon of lateral movement, assisting in the transfer of the ground water to places where it could find its way into the adjacent beds.

Synclines.-The more important ore bodies are found along the course of the main channels followed by the ground water. Obviously, synclinal structure would cause the convergence 'of solutions toward the axes of the synclinal troughs. While mineralization is not confined to such places, there are instances in the field where the ore is found in synclines. Professor Branner, in the report of the Arkansas geological survey, has emphasized the influence of folds in localizing the ore bodies and has advocated prospecting in such places for ores. Although ground waters have been influenced by the dip of the rocks, there are so many openings through which they may pass, such as fissures, breccias, joints, and solution channels, that the occurrences of ore outside of synclines are not exceptional.

Relations of belt of weathering and belt of cementation.-Under the action of atmospheric agencies the rocks at and near the surface suffer loss of their mate rials and waste away. This process may be described as weathering. Deeper in the earth the materials derived from the upper rocks are largely redeposited. This process is one of cementation. The belt of weathering and the belt of cementation are not separated by a sharp line, and, moreover, with the processes of erosion the lower limit of the activity of the atmospheric agencies has constantly migrated downward. These belts are related to the topography of the country, 
ZINC AND LEAD DEPOSITS OF NORTHERN ARKANSAS.

the plane separating them being higher in the hills than in the valleys. Consequently, during the long period which has been required for the removal of the

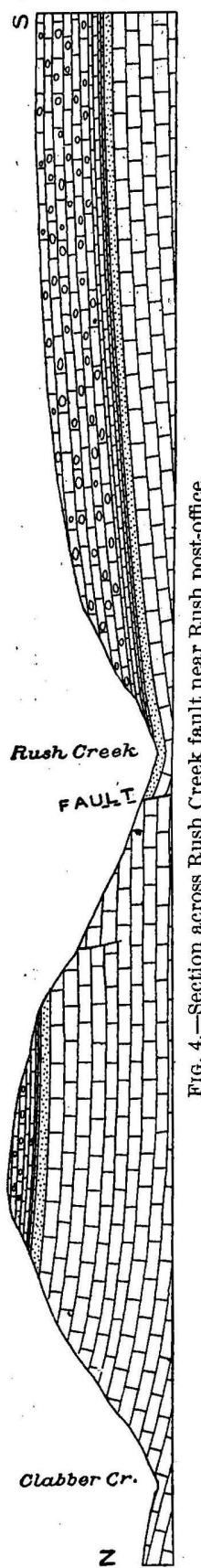
stratified rocks to their present limits there has been a shifting downward and southward as the streams have cut their valleys deeper and the escarpments have retreated to the south. In the northern part of the field the belt of weathering, which was formerly in the Mississippian limestones, has, since the removal of these beds, reached the Ordovician rocks. To the south, as a result of the rugged topography, it lies partly in the Ordovician and partly in the Mississippian. At the base of the Boston Mountains, where the shales and sandstones have been but recently removed from above the Mississippian limestones, the belt of weathering has descended but a short distance into the upper portion of this formation. The rocks in the northern portion of the zinc and lead district of northern Arkansas may accordingly be considered as exhibiting the more advanced stages of the processes of weathering and erosion.

\section{PRINCIPAL FAULTS.}

The faulting in the Arkansas field was not studied in detail, except within the Yellville quadrangle. The principal lines of displacement are shown on Pls. I, IV, and V. The presence of faults is shown by the contact of formations which, as a result of displacement, are not in stratigraphic continuity; or in case the fracture has the same formation on either side and the section is not exposed, by masses of fault breccias which sometimes stand above the adjacent rocks (PI. VIII, $A$ ). Only the more important structural lines are here described. A number of minor faults were noticed, and fault breccias were found which could not be attributed to definite lines of displacement, because of the absence of good surface exposures.

The faults described below have all been noted by the Arkansas geological survey. The interpretation of them here presented differs, however, from that of the State report. Professor Branner in his descriptions and diagrams has discussed them as thrust faults. The observations made during the present survey led to the belief that they are normal faults. This interpretation is consistent with the structural history of the region as outlined above. 
Rush Creek fault.-This fault is named from Rush Creek, which follows the fault line in many parts of its course. The displacement varies along the line of the fracture, and probably is greatest in the vicinity of Rush post-office, where it was measured and found to be about 350 feet (fig. 4). The mountain north of Rush is capped with the Boone formation, while these same rocks are exposed in the bed of the creek near the post-office. Northwest of Rush the rocks on the north side of the fault all belong to the Yellville formation, while to the south, except in the creek valley, the country is occupied by the Boone. The fracture may be observed in a number of places, particularly at the bend of the creek, about one mile above Rush. On. Spring Branch, just above the Climax mine, the line of the fault is indicated by a breccia. The displacement is accompanied by dragging of the beds on the south side of the fault, so that they turn up like sled runners when viewed in a section from south to north. There is evidence that the faulting is not confined to a single line of fracture, since at the Morning Star mine there is displacement with a downthrow on the south side along a line parallel to the main fault, and small displacements have been - ubserved in the workings of other mines, particularly the White Eagle, which is in the fault zone. The Climax mine is situated near a fault which is parallel to the main one, and which, like it, has a downthrow on the south side. The continuation of the fault to the southeast beyond Buffialo Fork could not be made out. It is not improbable that the displacement is taken up by the undulating structure of the rocks. This is inferred from the dips seen along the river between the mouth of Clabber Creek and the Silver Hollow mine.

Tomahawk fault. - The fracture which passes through secs. 7 and 8, T. 16 N., R. 16 W., in close proximity to the old Tomahawk copper mine, as it is called, brings the Carboniferous shales in contact with the Boone formation. It is well marked at many places. The throw reaches fully 350 feet.

Parallel with and south of this fault are the Pilot Mountain fault and a few others, which are not very clear in the field. They have a

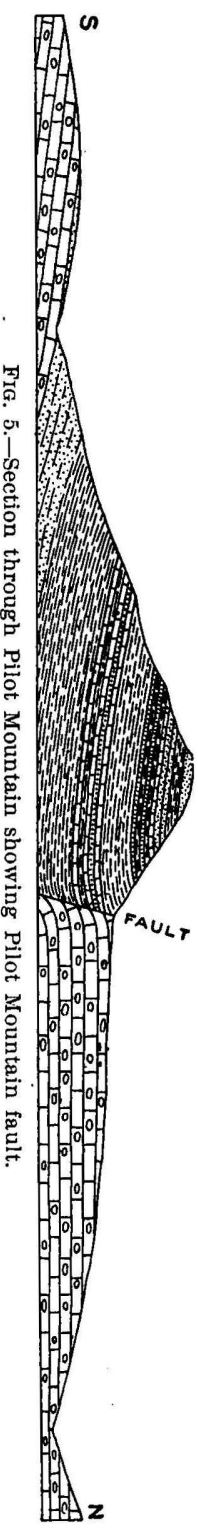
downthrow on the north side, and counteract the structure of the Tomahawk fault, so that the intervening area has been dropped as a block.

Pilot Mountain fault.-The northern border of the shale and sandstone area northeast of St. Joe is defined by a fault which passes along the north side of Pilot Mountain (fig. 5). It is very easily observed in the field, because of the 
dissimilarity of the rocks to the north, which belong to the Boone formation. Its direction is approximately parallel to the Tomabawk fault, and the two exhibit $\infty$ 泪 structural relations similar to those of the St. Joe fault.

St. Joe fault.-The St. Joe fault is north of and parallel to Mill Creek. The downthrow is on the south side of the fault, and the displacement measures between 250 and 300 feet at different points. Throughout a portion of its course the Boone is brought in contact with the Yellville formation (fig. 6), but in the valley of a north branch of Mill Creek, the Key, Izard, Polk Bayou, and the Sylamore are exposed in contact with the Yellville formation.

Mill Creek fault.-South of Mill Creek and nearly parallel with the St. Joe fault there is a line of fracture with a downthrow on the north side. The effect of this displacement, combined with the St. Joe fault, is to depress a narrow block, which, as a result of the drag accompanying the movement, has a synclinal structure. It is on this fault block that the portion of the valley of Mill Creek having a west-east course has been developed.

St. Joe monocline. - In the valley of Mill Creek, just north of St. Joe, the rocks are seen to be sharply flexed and to dip to the south. Around St. Joe they resume their nearly horizontal position, but dip to the north, forming a shallow syncline (fig. 6). The line of sharp flexure extends northeastward and joins the Pilot Mountain fault, as shown on the map, and it is not improbable that there is displacement along it in its northern portion. The St. Joe monocline, together with the Pilot Mountain fault, accounts for the presence of the Carboniferous shales and sandstones found around St. Joe at a lower elevation than would naturally be expected. To the southwest of the line of the St. Joe the monocline extends across Buffalo Fork toward the head of Cave Creek. These localities have not been carefully studied, but the monocline is known to locally pass over into faulting.

On the map published by the Arkansas geological survey a fault is shown extending in a northeast-southwest direction through

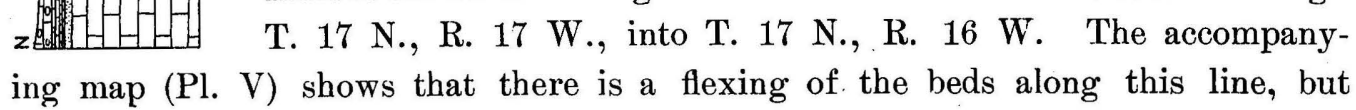
definite faulting was not seen, excepting in the southeast corner of T. 17 N., R. 17 W. The structure line is approximately parallel with the St. Joe monocline. 
A similar undulation in the rocks was observed on Water Creek and its tributaries in the southeast corner of T. 17 N., R. $16 \mathrm{~W}$.

Hurricane fault.- The Hurricane fault for a portion of its course follows Hurricane Branch, and to the west crosses Davis Creek. It appears to be a continuation of the St. Joe fault, or at least may be said to be a similar displacement which has apparently the same direction. It is clearly marked in $\mathrm{T}$. 16 N., R. 18 W., where shales and sandstones are found on the south side of it and the Boone formation on the north. In the valley of Hurricane Branch the displacement combined with erosion has exposed the Yellville formation on the north side in contact with the Boone formation on the south. Where it crosses Davis Creek it is marked by similiar relations. The Big Hurricane mine and the Spier mines are near the fracture, and their workings are in the breccia which has been produced by the dragging.

\section{ORES AND MINERALS.}

\section{SULPHIDE ORES.}

Zinc sulphide, or sphalerite.-This ore, which is commonly called blende, or "jack," is the most important one in northern Arkansas. It is composed, theoretically, of 67 . per cent of zinc and 33 per cent of sulphur; but as a result of the impurities the amount of metallic zinc.varies somewhat. The analyses of specimens from northern Arkansas average close to 66 per cent. The ore as marketed, however, does not always approach this purity, since in cleaning it is impossible to completely separate all other mineral matter from it. The price per ton is based upon ore which contains 60 per cent, and if assays indicate more or less the price is correspondingly higher or lower, usually the variation being $\$ 1$ for each per cent.

Lead sulphide, or galena.-This is the principal lead ore of northern Àrkansas. It occurs in well-defined cubic crystals, or as crystal aggregates. Pure galena contains 86.6 per cent lead and 13.4 per cent sulphur. When smelted it yields about 80 per cent lead, since a portion is volatilized and lost. The northern Arkansas ore contains practically no silver, which is sometimes found in galena.

OXIDIZED ORES.

Zinc silicate, or calamine.-The amount of metallic zinc in this ore is theoretically 54.2 per cent. Because of the fact that it is deposited secondarily and in intimate association with other materials from which it is difficult to separate it by jigging, the commercial product as marketed usually carries but from 40 to 50 per cent of metallic zinc. It is translucent, has a vitreous luster, and varies from nearly colorless to yellowish and brownish. It usually occurs in irregular masses, but on free surfaces forms bunches of thin, tabular crystals. It is 
commonly associated with zinc sulphide, from which it has been derived as an alteration product. The workings in which it is found usually carry more or less clay and so-called tallow clay.

Zinc carbonate, or smithsonite.-This ore, which is usually spoken of simply as carbonate, or sometimes as "dry bone," contains theoretically 52 per cent of metallic zinc; but specimens of this purity are rare, and the commercial product of necessity falls much below. The better grades of ore are somewhere between 40 and 50 per cent. Smithsonite assumes a variety of forms, the common one being the so-called gray carbonate, which resembles a limestone in texture. Another variety is of stalactitic form, which it assumes where the mass has been deposited in successive layers in cavities. When this form is broken it usually exhibits a banded structure, and when weathered the carbonate is seen to occur in sheet-like layers, slightly separated from each other, the intervening space being filled by other material, or in weathered specimens consisting of irregularly connected cavities from which some substances have been dissolved. Not infrequently smithsonite exhibits a mammillary or botryoidal structure. This is found where it is deposited upon free surfaces. The color of the ore varies according to the foreign substances which are present. Occasionally it has a yellowish color, in which case it is known as "turkey fat." This color is produced by cadmium sulphide, which is frequently combined with zinc ores. Much of the smithsonite has an earthy form, and not infrequently it has the appearance of yellowish or brownish sand. This is due to its having been deposited irregularly and in small masses within the rocks and to subsequent decay.

Hydrozincite.-Hydrozincite is the hydrous form of smithsonite, or zinc carbonate, i. e., zinc carbonate combined with more water of crystallization. It has a white or yellowish color and an earthy texture, somewhat resembling chalk. It is commonly associated with smithsonite.

Lead carbonate, or cerussite.-This mineral occurs in limited amount, associated with the deposits of galena, and is a superficial alteration product from that ore. It ean scarcely be said to be of commercial importance in northern Arkansas, although it is found in some shallow diggings. Usually it is seen as a coating over crystals of galena, or as a thin, white shell after the galena has been partly removed.

Hydrocerussite. - This mineral bears the same relation to lead carbonate that hydrozincite does to zinc carbonate, but is not common.

Tallow clay.-This is not a definite mineral, and is at present not an ore of zinc, as no means have been devised for smelting it. It contains a variable amount of zinc silicate, and is allied to calamine. It occurs filling pockets and seams, and when first exposed has an unctuous feel. The color is variable, and it may 
be mistaken for ordinary elay. Commonly, however, it may be distinguished by its behavior upon drying. When exposed to the air it cracks and shrinks in a peculiar way, as the result of the loss of water.

\section{ASSOCIATED MINERALS.}

Dolomite spar, or pink spar.-By far the most common mineral with which.the zinc of northern Arkansas is associated is pink spar, which is a crystalline form of dolomite and consists of lime and magnesian carbonate. It has rhombohedral faces, and the crystals exhibit sharp curved edges, which are particularly characteristic. Its pink color is apparent in fresh specimens. On weathering it becomes discolored. Gray spar, which has practically the same composition, is another form which dolomite assumes on crystallizing, but is more particularly associated with the magnesian limestones than with ores deposited in cavities.

Calcite, or tiff.-This mineral is simply a crystalline form of lime carbonate, and has the same composition as nonmagnesian limestones. It occurs sparingly in the district, although it is present in notable amounts in some of the mines. Its scarcity is probably due to the fact that lime in solution in the dolomitic rocks is associated with magnesium and forms pink spar. Scalenohedral crystals are found in certain cave-like openings or water channels in some of the mines.

Secondary chert.-An important class of zinc ores are those which occur embedded in chert, which is clearly secondary to the rock formations. Secondary chert has been formed by the redeposition of silica from solution. It should not be confused with the primary chert or flint commonly occuring as lenses and nodules. Its color is usually slightly bluish, but upon weathering it is whiter or is stained yellowish by iron oxide. Not infrequently masses are seen from which the ores have been dissolved out, in which case the casts of the crystals give it a honeycombed appearance.

Quartz.-This mineral, which is the crystalline form that silica assumes, is found as small or minute crystals coating free surfaces. The dolomites, which are more or less siliceous, sometimes have a cavernous structure, and these small openings are converted into quartz druses. Quartz is not important in the richer ore deposits, but it is characteristic of the leaner deposits in the siliceous dolomites.

Iron sulphide, or pyrite.-This mineral, which is sometimes called sulphur, or mundic, by the miners, has a golden-yellowish or brassy appearance, as a result of which it is often called "fool's gold." Most of the ore deposits of northern Arkansas are exceptionally free from this objectionable mineral. It occurs, however, in small amounts at many localities, and in a few openings is as abundant as the zine ore. At certain places masses are found occurring as pockets in the dolomitic limestones, but in such cases it has no commercial value. Associated 
with the iron sulphide are sometimes small amounts of chalcopyrite, which contains a small percentage of copper, and this has given rise to the statement that copper ore is found in northern Arkansas. A notable example is the somewhat celebrated Tomahawk mine, at which place a large amount of money has been expended in driving tunnels and sinking shafts. The ore found at this place consisted principally of pyrite, with a very small amount of chalcopyrite, and the occasional greenish and bluish stains have resulted from the oxidation of the chalcopyrite.

Chalcopyrite.-This mineral, which is not much different in appearance from pyrite, usually occurs as small crystals upon the surface of other ores or upon the dolomite. It has a somewhat bronzy look when the surfaces are fresh. Upon oxidizing it gives rise to a bluish or greenish stain, as a result of the copper which it contains being altered to the carbonates, azurite, or malachite. These stains are sometimes seen in zinc carbonate.

Gypsum.-The oxidation of sulphides, such as pyrite, sphalerite, and galena, gives rise to sulphate solutions. The metals are redeposited as carbonates, and the sulphuric acid with which they were combined goes into solution. It may react on limestone and form calcium sulphate, or gypsum. This mineral is found at a number of places. It has a clear, crystalline form, can be scratched with the finger nail, and the thin plates into which it splits can be slightly bent. These facts serve to distinguish it from calcite, which it somewhat resembles.

Epsomite.-"Epsom salt" may be formed in much the same way that gypsum is, but contains magnesium instead of calcium. It occurs as hair-like crystals in old workings.

Goslarite.-This mineral is hydrous zinc sulphate. It occurs in old workings as light-colored crystals or as a crust on the walls. It is formed from zinc ore in solution and represents a transitory stage of the process of ore deposition, since it may pass readily into solution.

\section{COUNTRY ROCK.}

The country rock in northern Arkansas, as will be gathered from the discussion of the geology, is either a limestone-bearing chert or a magnesian limestone, or dolomite, which is more or less cherty or siliceous. From these rocks the pink spar and calcite have probably been largely derived, as has also the secondary chert. The process of formation of these minerals is one of simple solution and redeposition, and took place along with the formation of the more important ores. These gangue minerals are of interest, inasmuch as they have a bearing upon the source and mode of desposition of the zinc and lead. 
PREVAILING GANGUE MINERALS.

According to the prevalence of gangue minerals the sulphide ore bodies may be placed in two classes, those occurring with a siliceous matrix of secondary chert or with quartz crystals, and those found with pink spar and calcite. One or the other of these conditions is usually characteristic of a mine, although they not infrequently are found together. The oxidized ores are the carbonates and silicates, which are simple alteration products which have been derived from these two classes of deposits. Usually they are not far from the sulphides, and frequently occur in intimate relation with them.

\section{GENESIS AND CLASSIFICATION OF THE ORE DEPOSITS.}

Source of the ores. - It is generally accepted that the zinc and lead deposits of this region have been formed by the action of circulating waters, which have dissolved the ores which were first broadly disseminated in the limestones. Water has dissolved and carried them in solution to certain places where the conditions were favorable for their redeposition. Stating it differently, they have been derived from the belt of weathering and the belt of cementation and largely deposited in the belt of cementation. A study of the nature of the ores and their gangue materials and of the geologic history of the region makes it apparent that at least the latest concentration of the ores in the Ordovician has been largely the result of downward and lateral movements. The metallic sul. phides may have been mainly derived from the Mississippian limestones, which formerly had a wider distribution, from the Ordovician, or from both formations. An examination of the Mississippian rocks shows that they have been leached by surface waters. Where they are exposed in railway cuts they exhibit decay to considerable depths, and within the area of their outcrop are numerous sink holes in which the water disappears into underground channels. The surface cherts which have been derived from the weatherings of those rocks are frequently porous and spongy, thus indicating the loss of silica. In the Ordovician secondary silica is not infrequently a gangue of the ores. The Mississippian limestones contain notable deposits of zinc and lead at many localities in the Ozark region, and where there, is ore in the Ordovician the area was formerly overlain by the Mississippian limestones. The mines of southwestern Missouri around Joplin are in this formation, and in northern Arkansas, as has already been stated, prospecting has shown that in the portion of the district where they have been but recently exposed to the action of surface waters, probably as a result of a first concentration, they carry considerable lead and zinc. 
Classification of the ore deposits.- The most important deposits of the district are the sulphide ores of lead and zinc, or, as they are commonly called, galena and blende. In the Ordovician dolomites there are two principal classes of these deposits, which are characterized by the gangue material. One class is distinguished by its occurrence with secondary chert, which occurs as a siliceous replacement of the dolomites, or filling fractures in these rocks; in the 'other there is associated with the ore a large amount of dolomite spar, which forms a cementing material in the breccias. In certain of the mines there is, in addition to these main ore bodies, accessory ore which replaces the country rock to some extent adjacent to the main ore body without developing secondary chert or spar.

In the Mississippian limestones the primary ore deposits are accompanied by secondary chert and calcite. They are related to fractures, and in some instances to fault planes. In the latter case they usually occupy breccias. Accessory ore replacing the country rock is sometimes present with these deposits.

The northern Arkansas field contains important deposits of oxidized ores. These are the carbonates and silicates. They are derived from the primary sulphides, and are due to the alteration of the sulphides by the action of surface waters. In discussing the genesis of the ores the important problem is the origin of the sulphide deposits, the relation of the oxidized deposits to the sulphide deposits being clearly evideut.

Processes of primary deposition of the sulphide ores.-The action of ground waters in the belt of weathering, and to a considerable extent in the belt of cementation, resulted in the solution and transportation of the ores. As the water percolated downward and moved laterally, and perhaps later upward, it reached a place where deposition took place. In the early part of the journey of the waters, through the action of the carbon dioxide and the humic acids, silica was taken into solution, and the waters accordingly contained it in notable quantities, as well as the ores in solution. In the latter part of the journey the action of these waters was the solution of lime and magnesium carbonate and the deposition of silica and sulphides, the resulting ores supposedly having been transported as sulphates. The reduction of the metals to sulphides was probably accomplished through the agency of organic matter and pyrite in the rocks, directly or indirectly, and deposition of the sulphides occurred along with the formation of the secondary chert and spar. The superposition of the original cherts in the Mississippian limestones and the occurrence of the secondary cherts and spar in the dolomites are entirely in accordance with this theory.

Processes of deposition of the oxidized ores.-The oxidized ores of northern Arkansas are the carbonates and silicates which have been derived from the sulphide ore bodies. They are, accordingly, relatively later, and have been pro- 
duced since erosion has brought the sulphides into the zone of weathering. The descending waters, carrying carbon dioxide, have transformed the blende and galena. In some cases redeposition has taken place immediately, and not infrequently oxidized ores are found as incrustations on the sulphides. In other cases they are found along water channels, or in the open spaces and on the surfaces of the country rock. In the exposed faces of ore-bearing beds and the upper portions of workings secondary ores often predominate. When mining operations are carried into the rocks that are under côver or have been protected from the action of ground waters, the carbonates and silicates decrease, and galena and blende are found to be the predominating ores.

Secondary deposition of the sulphides. - The sulphide ores which were dissolved by descending waters have not all been redeposited within the belt of weathering. Such portions as were retained in solution upon reaching the belt of cementation were redeposited as sulphides, the processes in this case being the same as in the primary deposition and the ore bodies belonging to a second generation. In the lower horizons of the Ordovician dolomites considerable zinc ore is found, which occurs as bright, clean crystals associated with drusy quartz or in openings formed by fracture. Such deposits are usually lean, and thus far no workable body of ore of this nature has been discovered.

Observations have not shown that there is a criterion for clearly distinguishing the secondary sulphide ores, which may have originated by migration from the primary deposits, since it is not improbable that the solutions at the time of the first concentration may have deposited most of their ore in the upper horizons, in which case the deeper deposits would have the characteristics above described and assigned to the ores of the second generation.

Sulphide deposits associated with secondary chert.-Where chert is the principal gangue of the blende and galena, deposition in the Ordovician has taken place by the replacement of the dolomites and the filling of fracture spaces and cementation of breccias. Secondary chert when freshly exposed usually has a bluish color. It may be distinguished from the other country rocks by means of its hardness, since it can not be scratched with a knife. It frequently has a banded or bedded appearance, which corresponds to the bedding of the original dolomite, and crystals of ore usually well formed and distinct occur within the mass. In case some of the sulphides have been leached out, molds of the blende are seen, which gives the chert a honeycombed appearance. The richer deposits appear to be related to fracture zones, and occur along the fissures and replacing the adjacent beds. The path of the ore-bearing solutions in descending has apparently been along fractures, and latterly along the bedding planes, and the mineralization decreases away from the fracture zone. 
Sulphide deposits in bedded breccias. - In the brecciated beds of the Ordovician dolomites the open spaces between the fragments have afforded channels for the ore-bearing solutions, and the precipitation of the sulphides and dolomite, or pink spar, has usually taken place without dissolving the country rock to any appreciable extent. The pink spar is not always accompanied by ore. The sulphides have been deposited in a somewhat local way, many factors being concerned. Not infrequently in prospecting breccias containing pink spar and but little ore are found, and where the breccias are ore bearing they usually show a decrease in the amount of ore when followed for a considerable distance.

Sulphide deposits in fissures. - In the Mississippian limestones most of the mines and prospects are related to fissures, the ore occurring in material filling the fissures, or in the fissure and the openings adjacent to it. These deposits differ from those in the fractured dolomites in being more clearly defined. The gangue is usually secondary chert and calcite. The walls of the fissures exhibit slickensiding, as a result of the movement, and often indicate horizontal displacement.

Sulphide deposits in fault breccias. - Where the Mississippian limestones have been displaced by normal faulting and the rocks have been dragged they often show brecciation. The angular fragments are largely primary chert, and the ore is associated with a calcareous and siliceous matrix which cements the breccia.

Sulphide ore in the country rock.-In many of the mines and prospects the country rock has not been mineralized. In other cases, for a short distance adjacent to the fissures and fractures and water channels, the ore-bearing solutions have formed what is here called accessory ore. The action in this case has been one of replacement. The country rock exhibits recrystallization and carries small crystals of ore. Where accessory ore is found the main ore body is usually rich, and there is a suggestion that deposition in the country rock resulted because of the large amount of ore in solution at these places. In the northern Arkansas district the scattered crystals of blende in the country rock are spoken of as disseminated ore. This term, unfortunately, is not quite appropriate, and, accordingly, the word accessory is suggested, since it does not imply the mode of deposition usually ascribed to disseminated ores. Accessory ore, being usually found associated with rich ore bodies, is looked upon by the prospectors as a favorable indication. The ore in secondary chert is not included under this head.

Ore associated with quartz druses.-Not infrequently in the Ordovician dolomites the lower ore horizons exhibit quartz druses and surfaces covered with minute quartz crystals. The ore occurs as clean, bright crystals deposited on the quartz. It seldom is found in large masses, but is distributed through the rocks. It probably represents a migration from higher horizons, but it may have been deposited from depleted solutions at the time of primary deposition. 


\section{PLATE IX.}




\section{PLATE IX.}

\section{HAND SPECIMENS ILLUSTRATING GENESIS OF ORES.}

Frg. $A$. Weathered specimen of dolomite; the more readily soluble bands have been removed in process of weathering. In this particular case the laminæ, which stand out in relief, carry more argillaceous and siliceous material, which is not so readily dissolved

Fig. B. Banded or laminated dolomite which has been recrystallized but carries no ore. The alternation of light and dark bands shows the lamination due to variation in the character of the material during the time of sedimentation.

FIG. C. Fragment of dolomite which has been largely replaced by silica. This secondary silica carries zinc blende, which was deposited during the process of replacement. The white bands, which are due to the lamination of the original dolomite, consist of argillaceous and siliceous material which has not been removed by the solutions that altered the rock. (From Big Buffalo mine, Marion County.) 


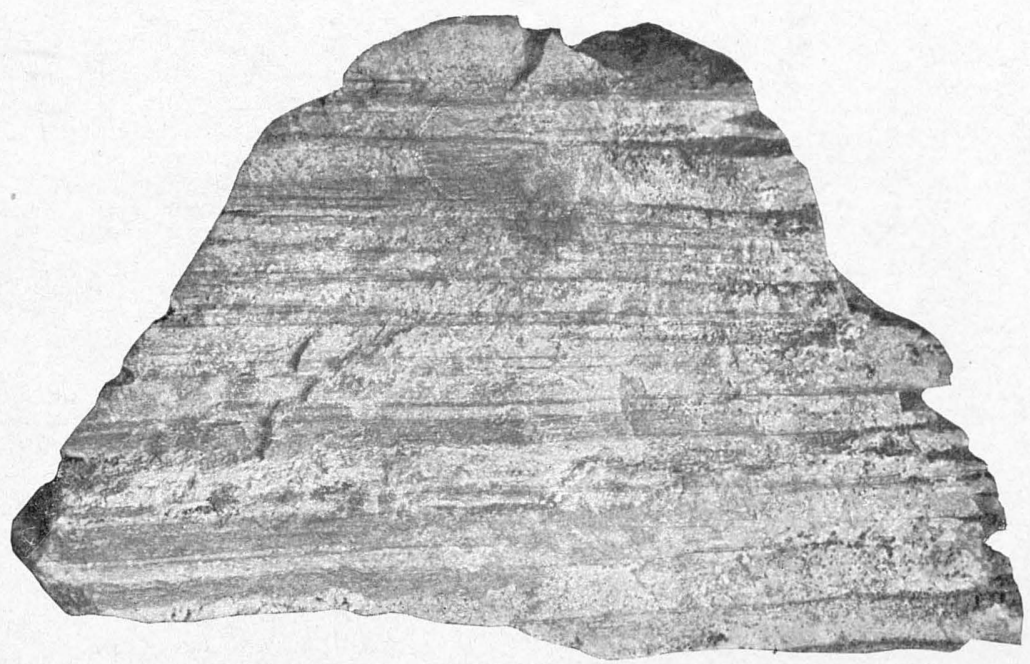

$A$
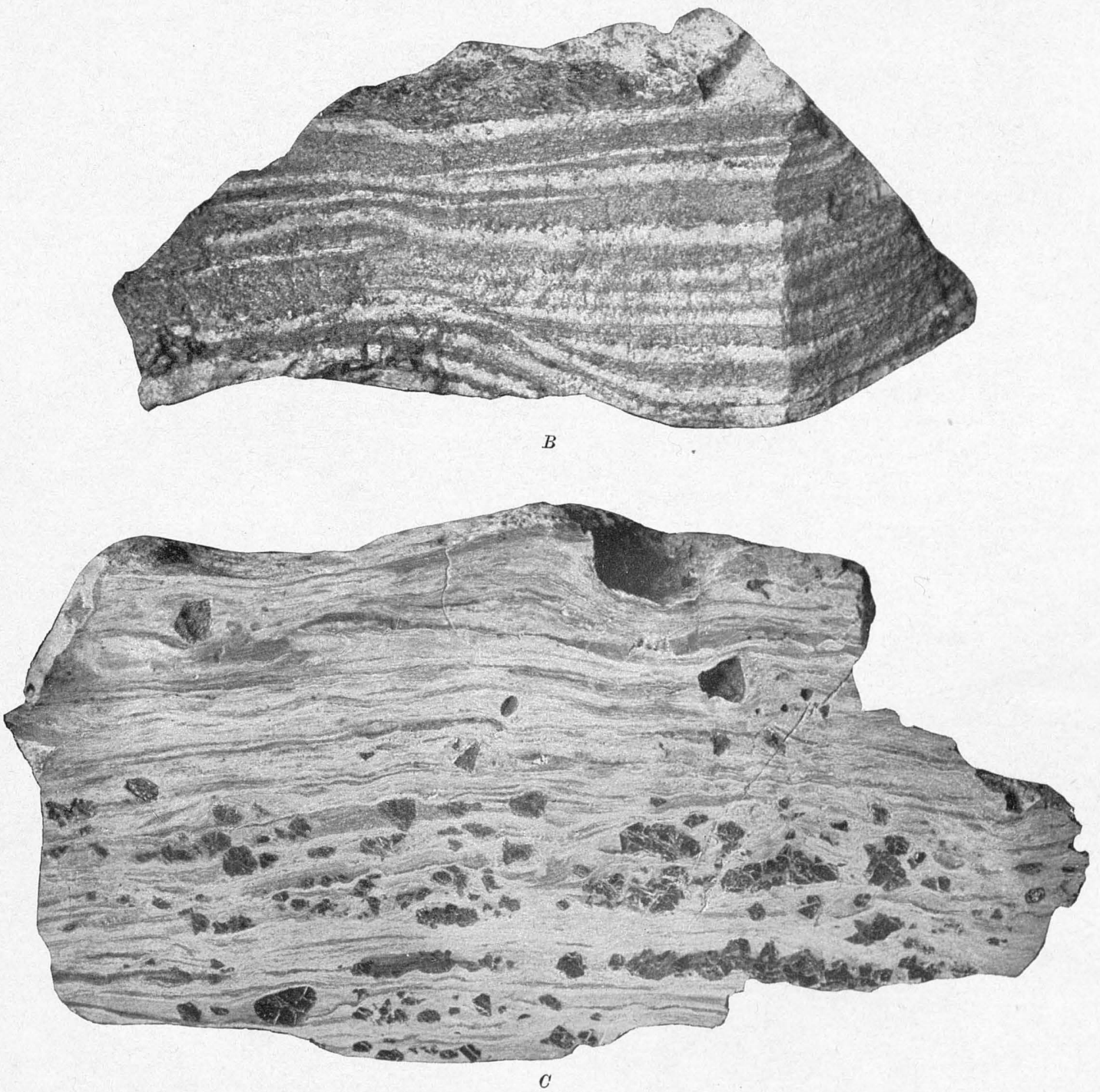

HAND SPECIMENS ILLUSTRATING GENESIS OF ORES. 

PLATE X.

4538-No. $24-04-4$ 
PLATE X.

HAND SPECIMENS ILLUSTRATING GENESIS OF ORES.

Fig. A. Illustrates the condition which a rock like the one shown on PI. IX, $C$, assumes when it has been subjected to weathering. The blende has been largely removed or altered in place to zinc silicate. (From Almy mine, Boone County.)

Fig. B. Specimen consisting almost. wholly of carbonate. The white lines indicate the argillaceous laminæ of the dolomite which the carbonate has replaced. (From Morning Star mine, Marion County.)

FIG. C. Fractured dolomite in which secondary silica carrying zinc blende has been deposited in the fracture. A small triangular piece of the dolomite is shown surrounded by secondary silica, and to the right of it there is a mass of sand grains which were carried into the fracture space at the time of the filling of it by the secondary silicate. (From Iola mine, Marion County.) 

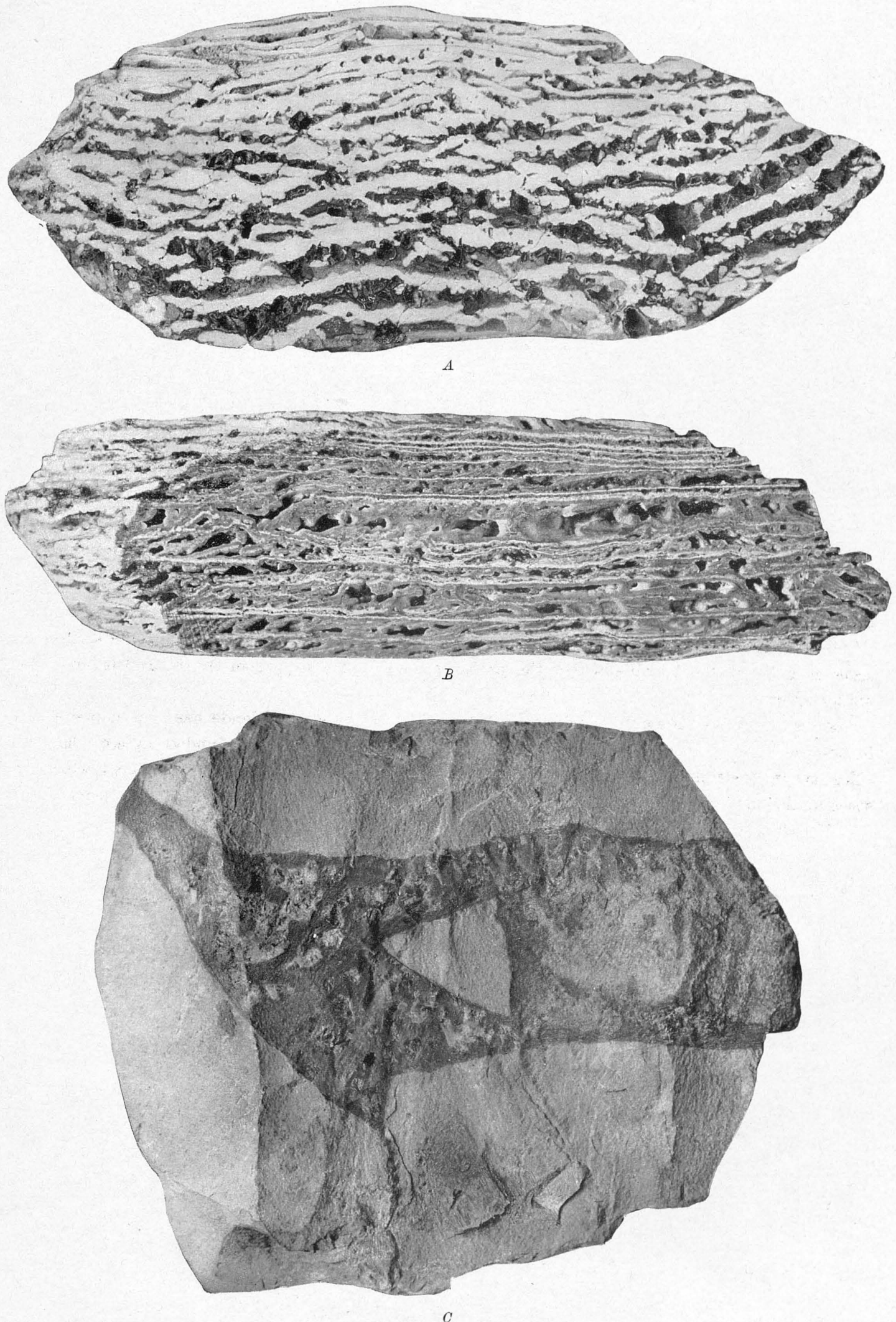

HAND SPECIMENS ILLUSTRATING GENESIS OF ORES 

PLATE XI. 


\section{PLATE XI.}

\section{HAND SPECIMENS ILLUSTRATING GENESIS OF ORES}

Fic. $A$. Mass of secondary silica which originally carried zinc blende. The ore has been entirely removed, leaving molds of the crystals of sphalerite.

FIG. $B$. Specimen illustrating the occurrence of galena in secondary chert. (From Ben Harrison mine, Marion County.)

Fig. C. Specimen of secondary silica, in the surface of which large crystals of zinc blende were deposited. The ore, however, has been removed. The cavities preserve distinctly the angles and planes which bounded the crystals. (From Markle mine, Marion County.) 

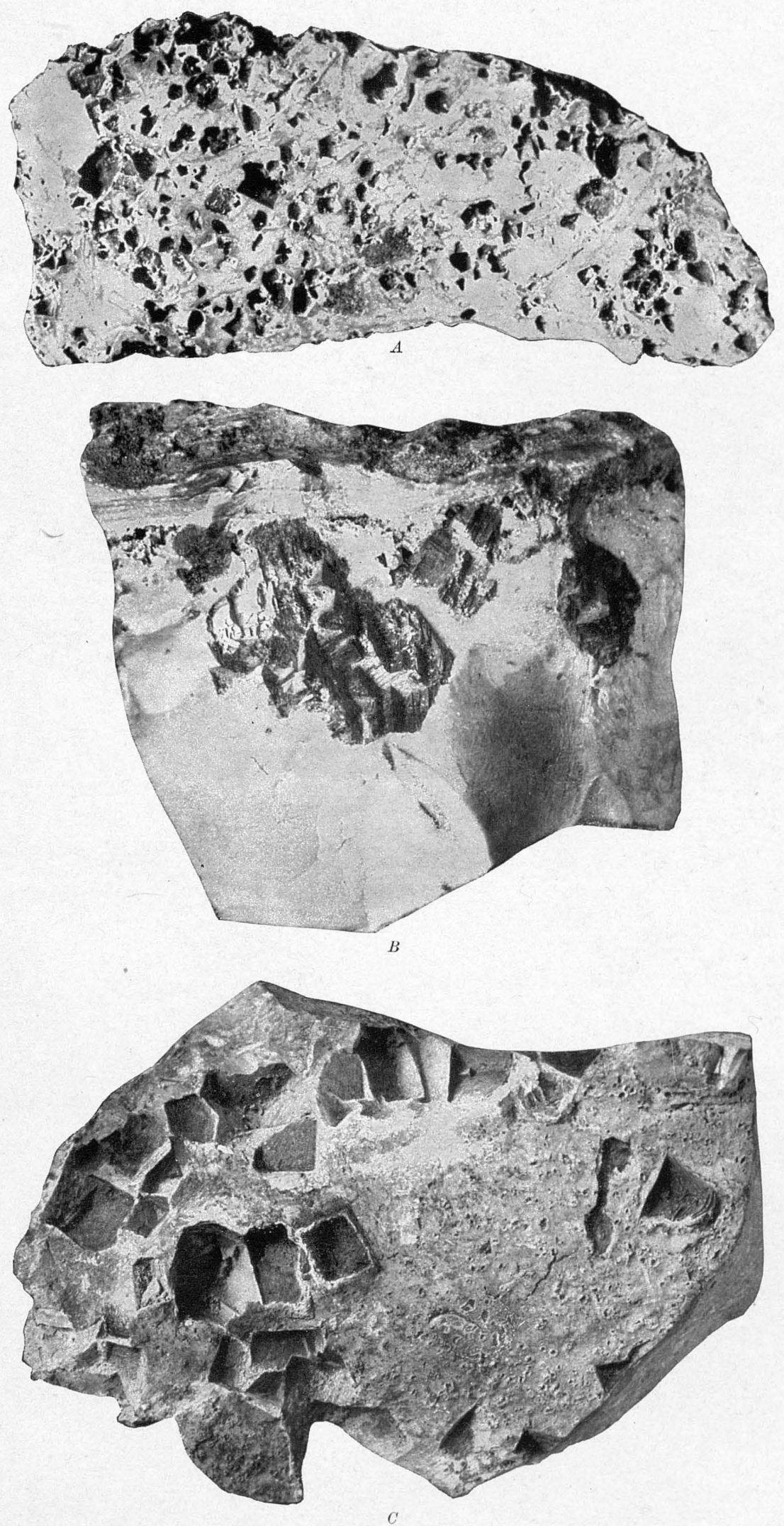

HAND SPECIMENS ILLUSTRATING GENESIS OF ORES. 

PLATE XII. 


\section{PLATE XII.}

\section{HAND SPECIMENS ILLUSTRATING GENESIS OF ORES.}

Fig. $A$. Section through a crystal of galena, the outer portion of which has been altered to carbonate, forming a shell of this material enveloping the crystal.

FIG. $B$. Weathered breccia which originally was much like $C$. The thin plates in it are due to the laminæ of the original rock, and the cavities are due to the removal of zinc blende, which was deposited during the process of silicification. (From Big Buffalo mine, Marion County.)

Frg. C. Fragment of breccia with a matrix of secondary silica. The angular pieces have resulted from the breaking of the laminated rock, which has been altered in the process of silicification. The secondary silica exhibits two phases, a dark and a light. Evidently there was some movement after the dark portion of the matrix was deposited, and the openings which were formed then were subsequently filled by the light matrix. Both the light and the dark secondary silica carry zinc blende in more or less definitely defined crystals. (From Markle mine, Marion County.) 

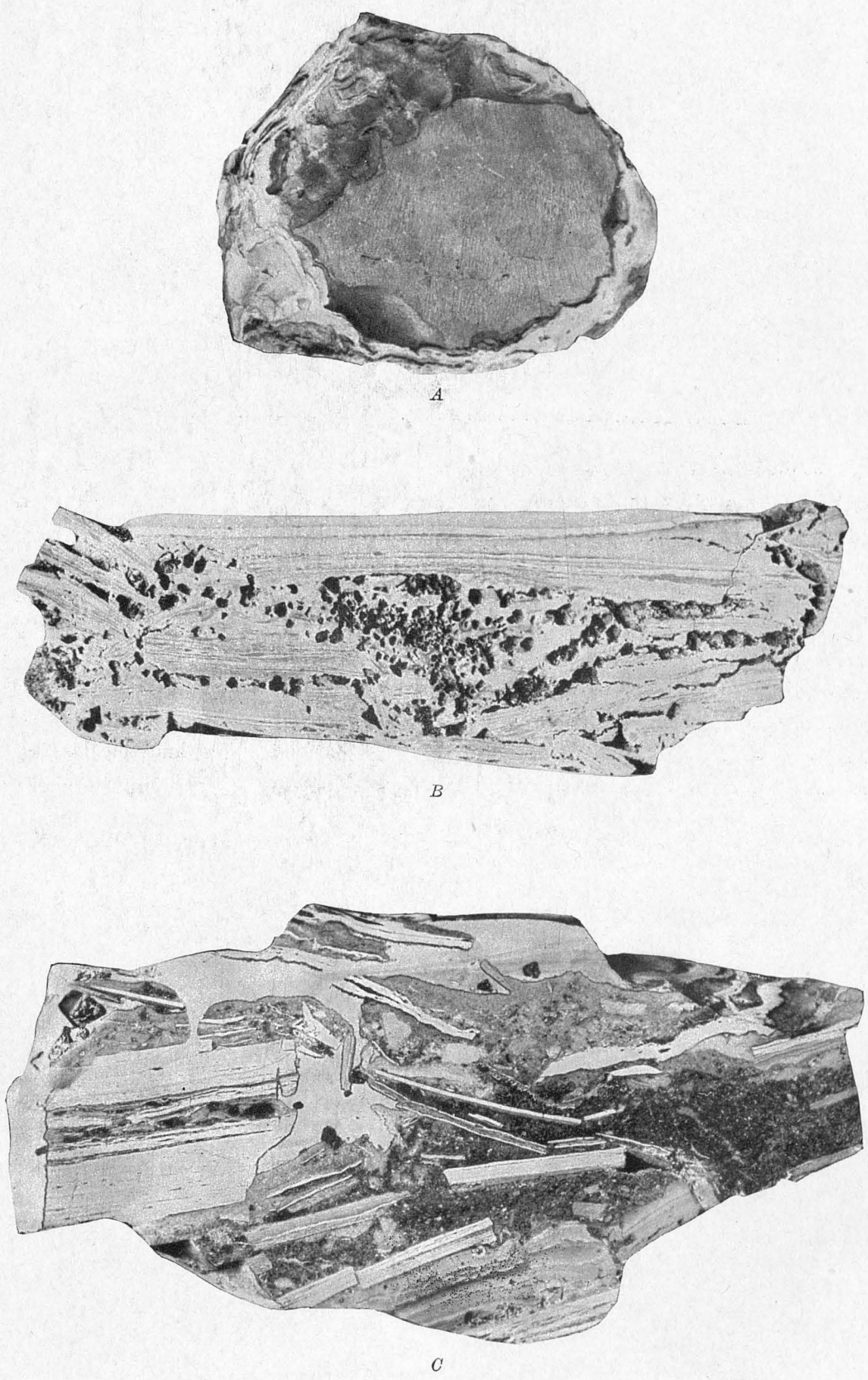

HAND SPECIMENS ILLUSTRATING GENESIS OF ORES. 

PLATE XIII. 


\section{PLATE XIII.}

HAND SPECIMENS ILUUSTRATING GENESIS OF ORES.

Frg. A. Mass of pink spar which was deposited in a breccia. Crystals of zinc blende exhibiting characteristic faces of this mineral are shown embedded in the spar. (From Red Cloud mine, Marion County.)

Fic. $B$. Brecciated dolomite similar to the foregoing, in which the cementing material is nearly all zinc blende, and consequently is rich in ore. The lightest material is dolomite spar. (From Michigan mine, Baxter County.)

Frg. C. Specimen from a weathered breccia in which the angular fragments are dark dolomite. The lighter material is dolomite spar, or pink spar, which was deposited as cementing material. It carries some blende. (From Beulah mine, Marion County.) 

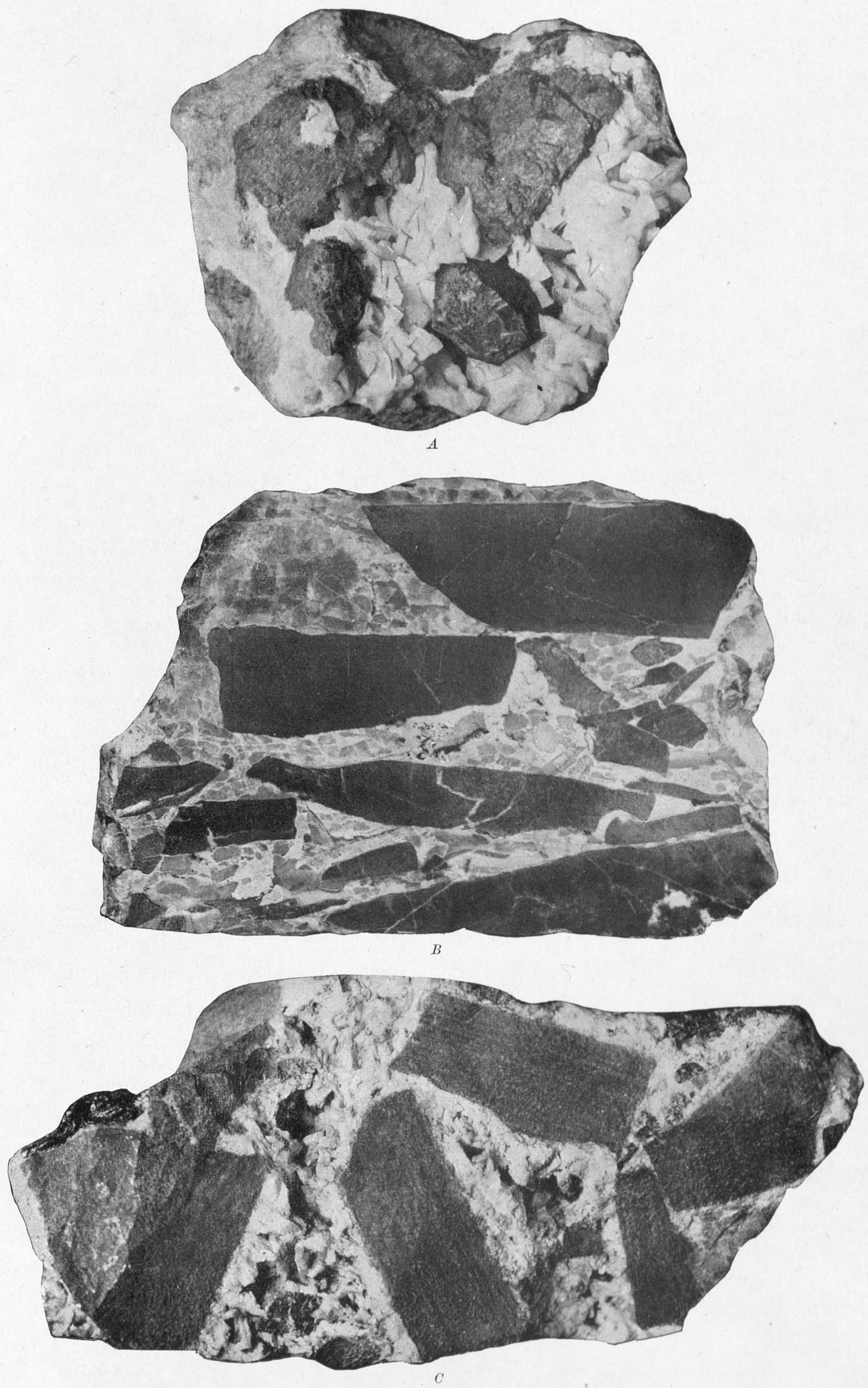

HAND SPECIMENS ILLUSTRATING GENESIS OF ORES. 



\section{PLATE XIV.}




\section{PLATE XIV.}

\section{HAND SPECIMENS ILLUSTRATING GENESIS OF ORES.}

Frg. $A$. Mass of pink spar which originally carried on its surface small tetrahedrons of chalcopyrite. Weathering agencies have altered the chalcopyrite to limonite, and the small amount of copper has given a green stain to the zinc carbonate which has been deposited in round points and irregular masses on the dolomite. Unfortunately, this plate does not show the colors of the various minerals, and is consequently somewhat confusing. Those who are familiar with the ores of the district will, however, recognize the characteristic appearance. (From Maumee mine, Searcy County.)

Frg. B. Fragment of rock which was once covered with pink spar. Zinc carbonate was deposited on the surface of the dolomite crystals so that they were completely covered. Solution has removed the pink spar, and the cavities where the specimen has been broken reveal the space which the spar originally occupied. (From McIntosh mine, Marion County.)

Fig. C. Section through a mass of zinc carbonate which was deposited as a stalactitic growth. The spaces between the layers of carbonate were probably once occupied by calcium carbonate which has been dissolved out during the weathering of the specimen. (From Carbonate Nose prospect, Newton County:) 

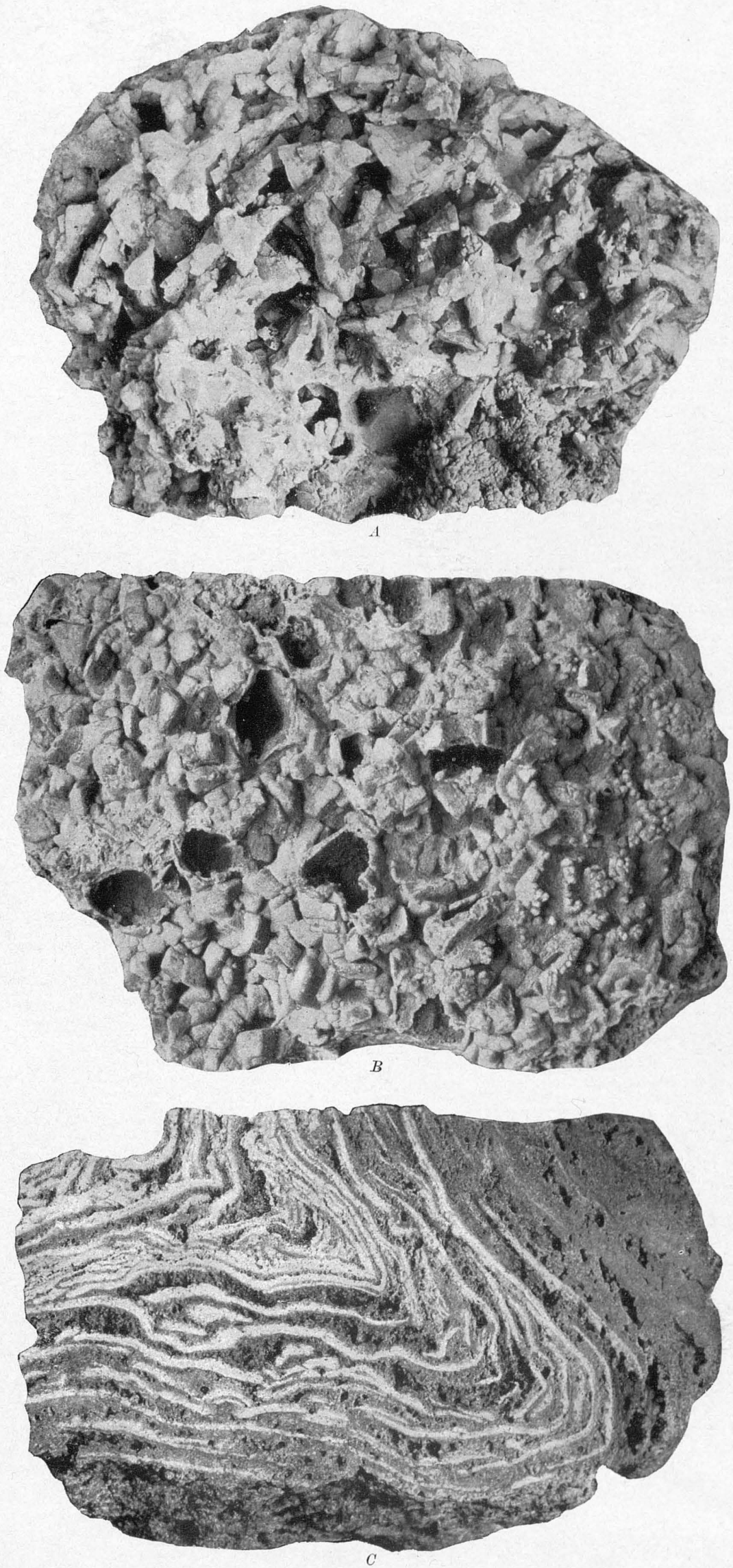

HAND SPECIMENS ILLUSTRATING GENESIS OF ORES. 

PLATE XV.

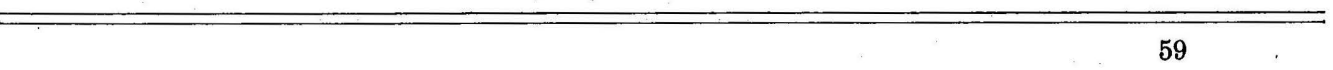




\section{PLATE XV.}

\section{HAND SPECIMENS IILUSTRATING GENESIS OF ORES.}

Frg. $A$. Section through an ore specimen the basal portion of which is zinc blende. The blende has been largely altered to zinc carbonate, which has been deposited on the free surface in botryoidal masses. The white portions consist of hydrous zinc carbonate, or hydrozincite. The centers of the concentrically arranged carbonate are remnants of blende crystals. (From McIntosh mine, Marion County.)

Fig. $B$. Specimen of zinc carbonate in which rounded masses are smaller and have grown from many points. (From Iola mine, Marion County.)

FIG. C. Characteristic appearance of botryoidal or mammillary zinc carbonate, which was deposited on a free surface. (From Morning Star mine, Marion County.) 

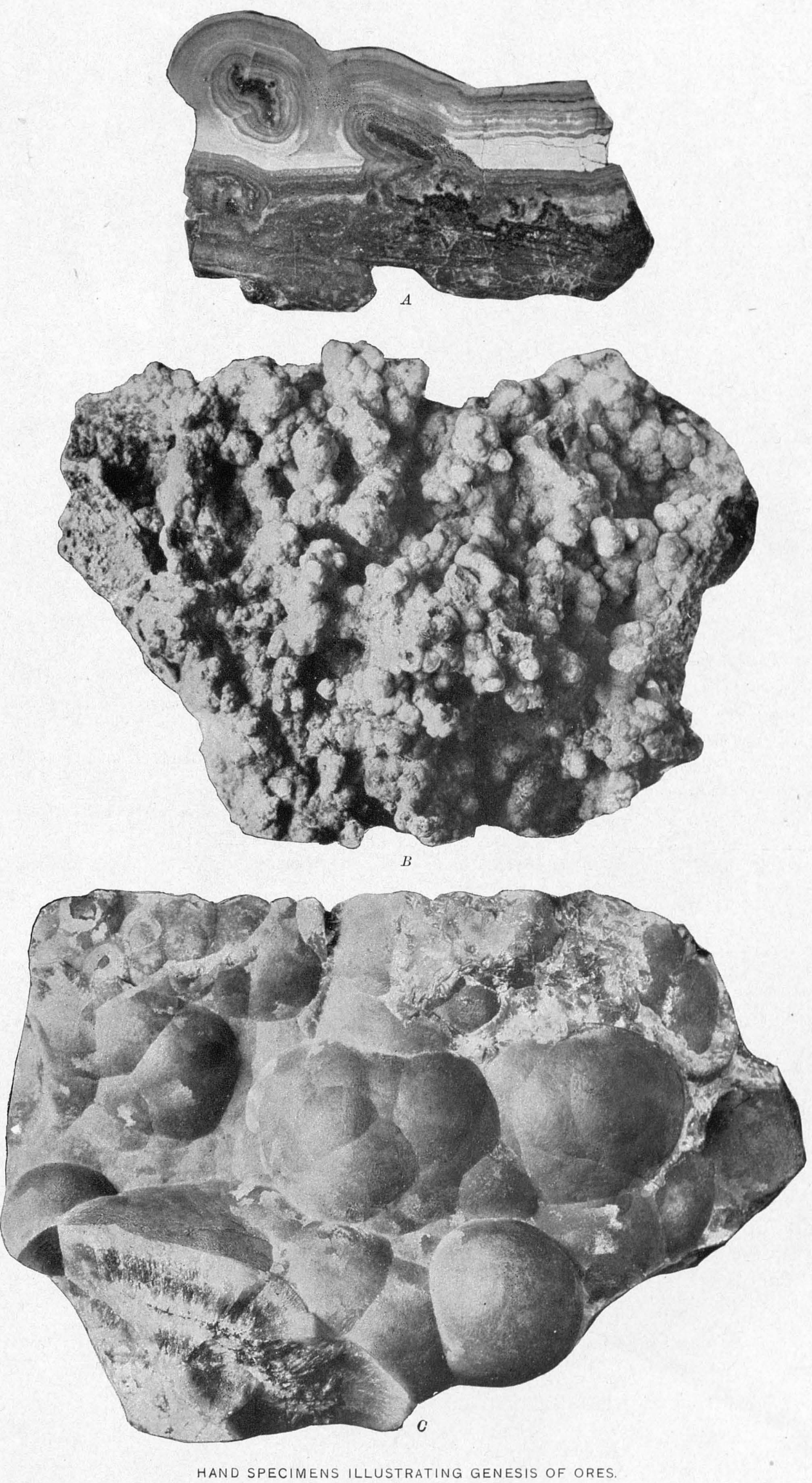

PLATE XVI.

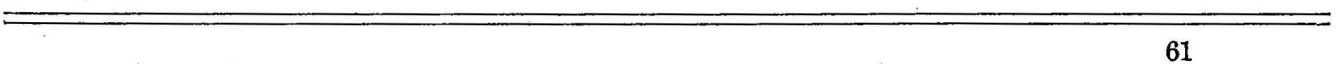




\section{PLATE XVI.}

\section{HAND SPECIMENS ILLUSTRATING GENESIS OF ORES.}

Fig. $A$. Fragment of barren breccia from the Yellville formation which shows the effect of squeezing in shaly beds. (From Susquehanna mine, Marion County.)

FIG. B. Fragment of brecciated Boone chert, with a matrix of secondary silica. This specimen carried no ore. The angular pieces of chert have been much displaced. (From Rush Creek fault in Crystal Springs ravine.)

Frg. C. Section of a second specimen of Boone breccia, in which the chert fragments have not been moved far from the original positions. This specimen carried some ore, which has been dissolved, leaving casts in the matrix. (From Rush Creek fault in Crystal Springs ravine.) 

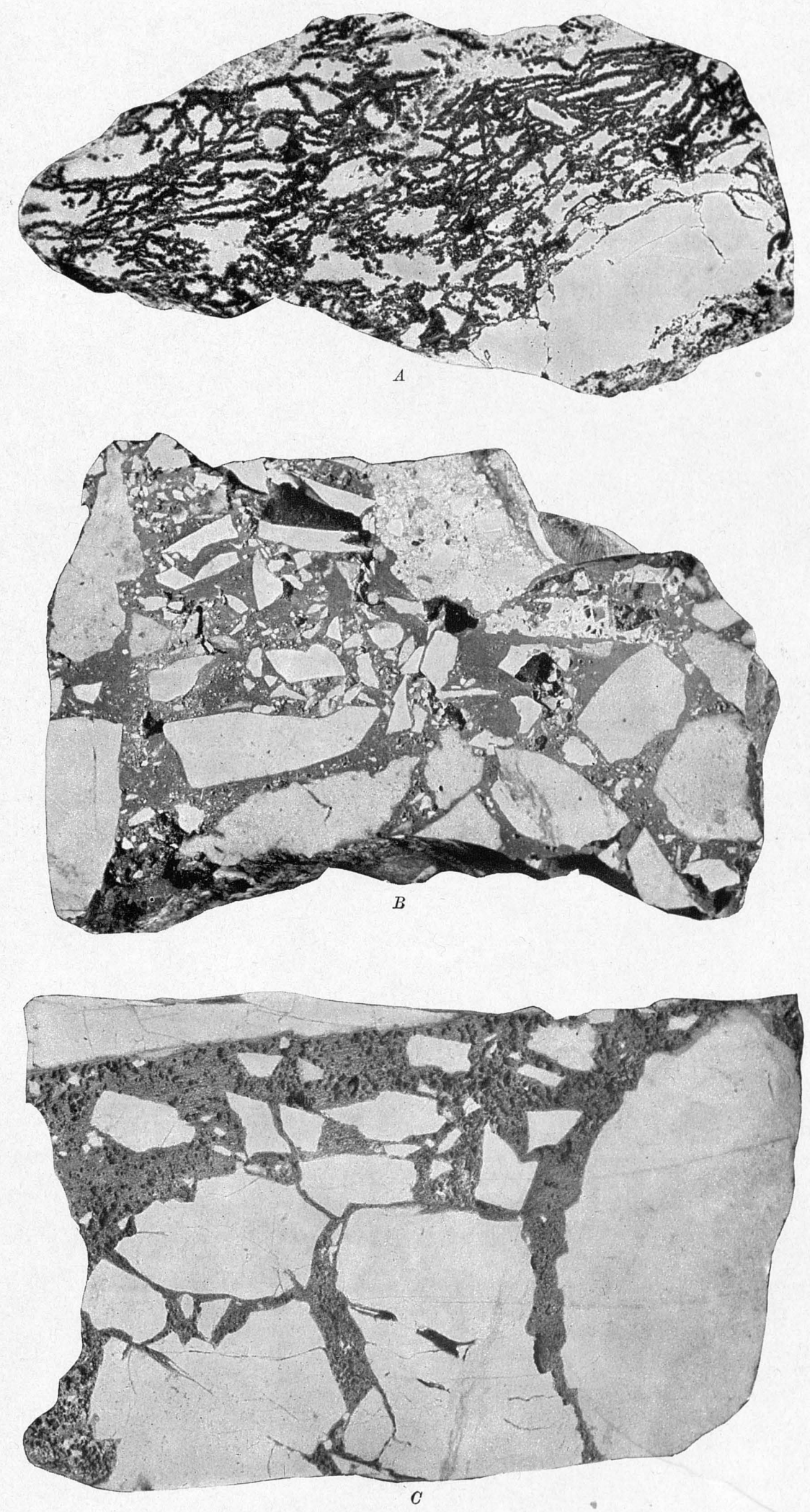

HAND SPECIMENS ILLUSTRATING GENESIS OF ORES. 



\section{DESCRIPTIONS OF MINES AND PROSPECTS.}

In the following descriptions not all of the mines and prospects of the district are mentioned. It is the purpose to set forth here such information concerning the district in general as will be valuable in forming conclusions in regard to the origin, character, and extent of the ore bodies. In the report on zinc and lead by the geological survey of Arkansas the descriptions of the mines and prospects are especially complete. The amount of development work done since that report was prepared is relatively small, except at certain mines, which are included in the following descriptions.

No attempt is made to divide the district into subdistricts or mining camps, since the ore deposits are not confined to definite areas. In taking up the descriptions, however, they will be grouped by counties. As has already been pointed out, the mines might be referred to two classes, according to the formations in which they occur, viz, those in the Yellville dolomites and those in the Boone limestone and chert. This will be kept in mind in the descriptions. In some cases the precise location of the prospects and the correct name of the property could not be learned, because the land lines could not be found and no one was present to furnish information.

BOONE COUNTY.

The development in Boone County is principally along Crooked Creek, beginning $2 \frac{1}{2}$ miles east of Harrison, and on Sugar Orchard Creek. In these valleys the Ordovician rocks are exposed. There are some prospects near the head of West Sugarloaf Creek, and considerable work has been done in the valley of Bear Creek and its tributaries. At these localities the Yellville dolomite is the orebearing formation. The northern part of the county will probably be more thoroughly prospected when the extension of the Missouri Pacific Railway is built through it. Some of the showings of ore there are encouraging. The localities on Bear Creek are not specially described in this report. The conditions in that part of the county are very similar to those where developments are more extensive.

Northern Star.-This mine is situated about $3 \frac{1}{2}$ miles northeast of Harrison, on Crooked Creek- It is in the SE. $\frac{1}{4}$ sec. 1, T. 18 N., R. 20 W. The opening occurs in the bluff of the creek, about 80 feet above the level of the water, and consists of a tunnel driven just below the Key sandstone. The country rock is dolomite, occurring in heavy ledges, but exhibiting locally thin bedding or lamination. The rock has been fractured and jointed and shows slight undulations. 
The ore occurs principally in a matrix of secondary chert, which is a siliceous replacement of the dolomite. Hand specimens show thin banding where the original structure is not obscure, and these bands correspond to laminæ of the dolomite. When traced for a short distance, the unaltered condition of the rock may be seen where it is exposed in adjacent openings. The ore-bearing stratum varies from 3 to 4 feet in thickness, and is rich in zinc blende. Some pink spar is found in this mine, and a minor amount of secondary ores, which have resulted from the alteration of the zinc sulphide, occur as coatings on the blende where it is in large masses, and also upon the gangue and associated minerals. At the end of the main tunnel is seen an open fissure, or joint plane, beyond which the country rock is apparently not mineralized. This opening has evidently been enlarged by solution, so that it resembles a narrow cave. Side tunnels from the main one pass through ore which varies somewhat in richness and promises to extend into the hill along the fractures which the beds exhibit. The amount of work done thus far has developed a considerable ore body. About 200 tons of crush rock were on the dump at the time the mine was visited. This horizon is known to be ore bearing at adjacent localities, and has been prospected on the adjoining property, known as the Anna, where a shallow cut has developed ore similar to that found at the North Star. 'Some prospecting has also been done lower in the bluff and in the creek bed, and a hole has been drilled on the bottom land on the opposite side of the creek. More or less zinc ore has been reported in the lower horizons. As observed by the writer, the dolomites in this locality, which are lower in the section, exhibit quartz druses, and the ore is found associated with these cavities. Not enough work has been done in this mine to determine whether the ore in these lower horizons occurs in commercial quantities.

Willis.-This opening is in the NE. $\frac{1}{4}$ sec. 23 , T. 20 N.,'R. 19 W., near the top of a small hill. It exposes a bed of fractured dolomite. The horizon of the ore is but a short distance below the Key sandstone and St. Joe limestone member. It can be traced around the southern end of the hill, and has been prospected at several places. At the main opening the dolomite has been sheared somewhat, but does not form an open breccia, as is frequently the case. The ore is found cementing the fragments of dolomite, and carries a small amount of pink spar as gangue. The strata above and below the ore bed are barren, and exhibit only jointing.

Elixir.-This prospect, situated in the SE. 1 sec. 25, T. 20 N., R. 19 W., consists of an open cut. The ore is principally galena associated with chert in gray dolomite, and occurs in pockets. Considerable ore has been taken from this place. Across the ravine to the south there is an open cut and a tunnel. The 
country rock is a close-textured blue dolomite, full of cavities lined with quartz crystals. These cavities carry some blende and carbonate.

Almy.-This property (Pl. XVII, B) is in the NE. $\frac{1}{4}$ sec. 17, T. 19 N., R. 18 W., in a hollow tributary to Mill Creek from the west. A number of openings have been made, all of which show more or less ore. The principal tunnel which was worked at the time the mine was visited was producing mainly silicate ore. The workings were all relatively near the surface, and the rocks show the result of surface decay. The original ore is apparently zinc blende, deposited in a secondary siliceous matrix. The tunnels show that the rock was fractured and displaced before the deposition of the ore. Narrow fissures which are ore bearing were observed transverse to the bedding, and the ore was also seen in sheets parallel with the bedding planes. As a result of the action of surface waters, much of the original blende has been leached out and altered to silicate, the secondary chert in such cases exhibiting a honeycombed structure. In the face of the main tunnel both the original and secondary ores were seen, and the rock exhibited openings filled with tallow clay. Farther up the hill shallow shafts indicate that the rock is of a similar character. The ore from this property, as it is mixed, is somewhat difficult to mill, but by judicious hand picking and sorting of the ore the milling is successfully accomplished. At the time this mine was visited the mill had been overhauled and work on the property resumed in a systematic manner. It was the only mine in the district which could be considered as having a steady output. Prospecting with the drill showed the presence of ore in lower horizons, and a shaft is being sunk in order to determine the nature of the bodies. The indications are that, inasmuch as the old openings are under shallow cover, only mixed ores can be expected from them until they are driven a considerable distance in the hill. The results of the deeper workings will be of considerable interest in determining the amount of mineralization at this locality. The level of the main tunnel is about 50 feet below the Key sandstone, but ore has been found at higher levels.

Jackpot.-On the opposite side of Mill Creek from the Almy there is an extensive open cut or stripping in the ravine, which is known as the Jackpot property. The ore occur's in a bed of brecciated dolomite which is about 3 feet thick, and consists principally of blende deposited with pink spar. Some calcite is associated with it. The ore has been altered to a limited extent to carbonate and silicate. The amount of brecciation in the beds varies from place to place along the exposure, and the ore is variable in richness. A large amount of crush rock is piled up, but thus far no ore has been marketed. This property is particularly interesting, because it is situated relatively. a short distance from the Almy and exhibits conditions which have not been discovered in that prop. 4538-No. 24-04-5 
erty. The same bed of dolomite is probably present on the west side of Mill Creek, although no opening has been mäde to prove this fact. Apparently the processes which resulted in the formation of the ore in the Jackpot are altogether different from those which produced the Almy deposit. In the one the gangue mineral is largely dolomite spar, in the other secondary chert. The suggestion is strong that the ores of the Jackpot may have been derived from the deposits on the opposite side of the creek, at a time previous to the development of the present drainage, and when the rocks were continuous. across the valley. If so, it is to be regarded as having migrated in solution, as already described in discussing the origin of the ore deposits.

Frisco.-In the same section, on Mill Creek, about a half mile south of the Almy and Jackpot, are located the prospects known as the Frisco property. They occur on both sides of the stream, and show more or less ore which is not unlike the Almy and Jackpot.

Virginia J.-The Virginia $J$ is in sec. 29, T. 19 N., R. $18 \mathrm{~W}$. The development consists mainly of an open cut 40 feet long in the bed of a creek that crosses a small syncline. There is also a shaft several feet deep, from which it is claimed a good deal of ore was taken; but at the time the place was visited this was filled with water. The ore is zinc blende, in considerable quantity, and occurs in dolomite, about 75 feet below the St. Joe marble. It is confined to the syncline, where the dolomite is much brecciated. There is a small amount of calcite, which with the ore forms the cementing material of the breccia.

\section{MARION COUNTY.}

The Ordovician rocks are extensively exposed in Marion County, in which are some of the best-known mines of the district. The ore-bearing horizons, which are in the upper portions of the Yellville formation, occur principally on the headwaters of Sugarloaf, Music, Jimmie, George, Sugar Orchard, and Tarkiln creeks, in the northern part of the county, and on Clabber Creek, Rush Creek, and in the valley of Buffalo Fork, in the southeastern part. Some prospecting has also been done in the southwest corner of the county.

Iola.-The development work at this place consists of some shallow shafts and open cuts (Pl XVII, $A$ ). The property is in the SE. $\frac{1}{4}$ sec. 25 , T. 20 N., R. 18 W., in magnesian limestones immediately below the Key sandstone horizon. The sandstone is not conspicuously developed at this place, evidently having been eroded before the deposition of the St. Joe limestone member. This formation can readily be found. At the principal cut worked when this property was visited the rocks were fractured and displaced. The richest ore occurred in the breccia, associated with pink spar and considerable calcite. Besides blende, there is some galena. A 


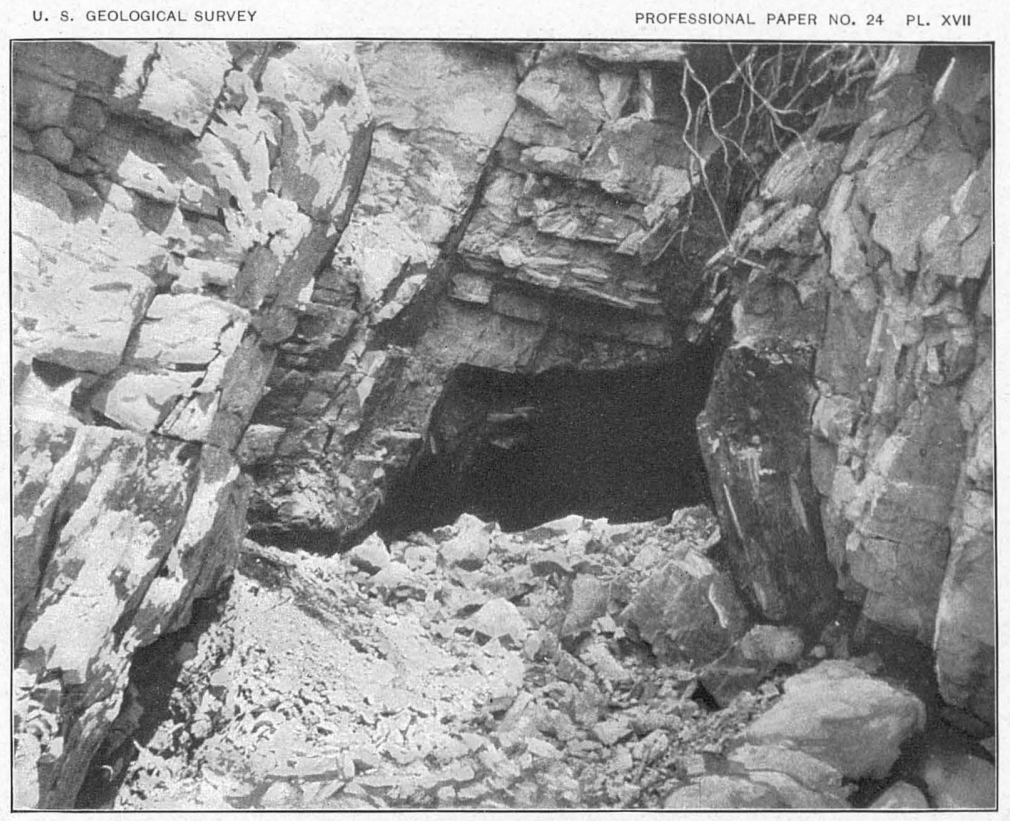

A. OPEN CUT IN BARREN GROUND NEAR IOLA MINE, SHOWING JOINTED DOLOMITE.

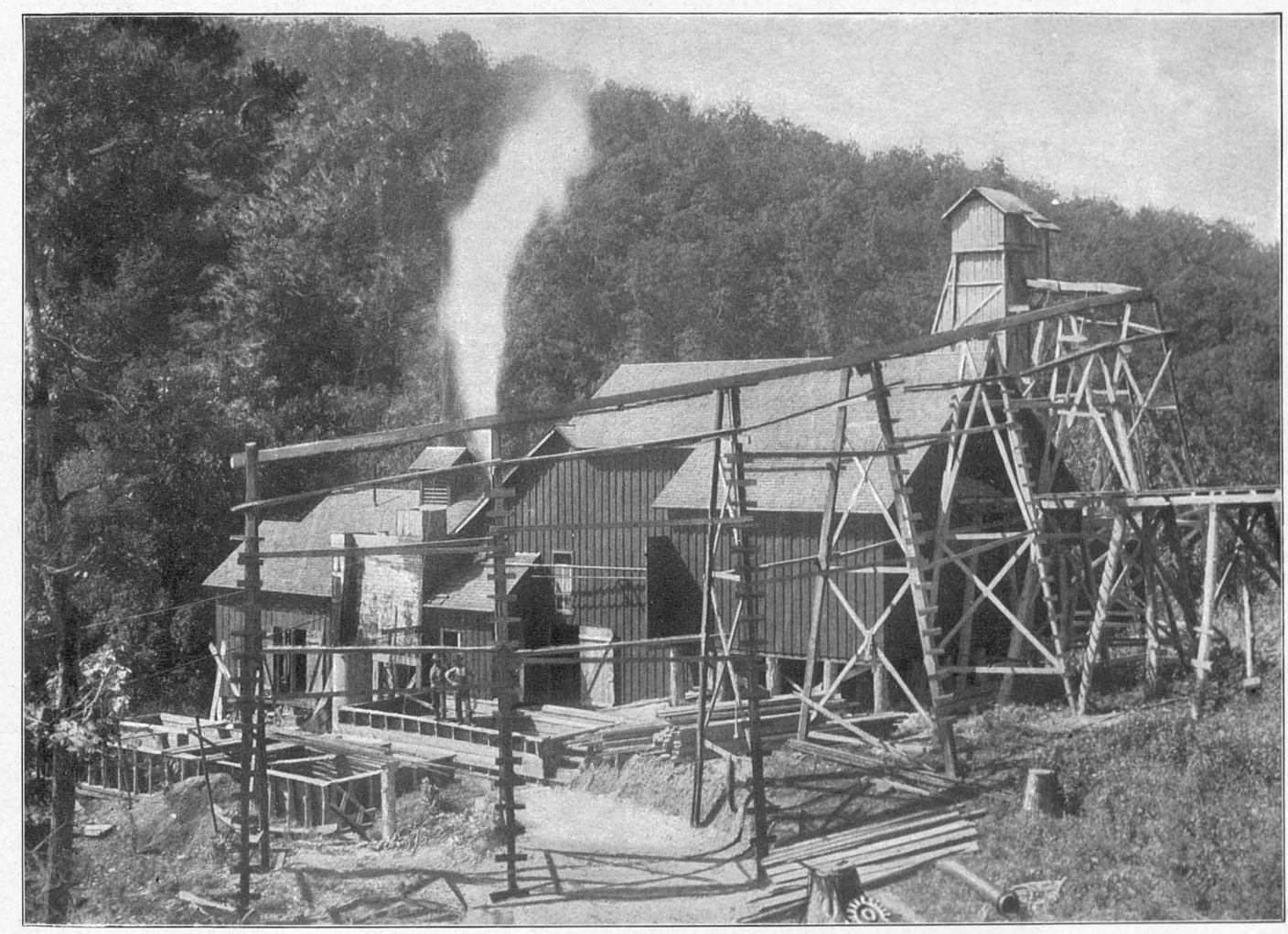

B. ALMY MINE. 

fissure a few inches wide was seen filled with a sheet of this mineral. At shaft No. 7, blende oecurs in a siliceous matrix which fills the fractures in the dolomite and occurs along the bedding plane. Ore of the same character is found to some extent in the other openings. A tunnel driven into the country rock where it carries practically no ore exhibits the jointing or fracturing, which has developed principally along a north-south course. 'There is considerable evidence of displacement at the Iola property, although no estimate of the amount could be obtained. Altogether it probably does not exceed a few feet. The ore deposits at this place, as at a number of others indicated in the descriptions, seem, however, to be related to this structure.

Tallow Clay.-This opening is in the SE. $\frac{1}{4}$ sec. 35, T. 20 N., R. 18 W., not far distant from the Iola. The development consists of a shaft a few feet deep, and a tunnel driven several feet into the hillside, mainly along a clay-filled cavern in dolomite. A small amount of tallow clay and zinc carbonate were taken from the workings.

Colorado.-This mine is in the NW. $\frac{1}{4}$ sec. 36, T. 20 N., R. 16 W. The development consisted, at the time of visit, of a shaft several feet deep, which then was not being worked and contained so much water as to prohibit inspection. The shaft was sunk in a zone or belt of crushing similar to that in which the Markle is located. A few tons of good crush rock had been taken from the shaft, the ore being blende, and occurring in breccia.

Ben Harrison.-This property is in the SW. $\frac{1}{4}$ sec. 25, T. 20 N., R. 18 W. The development is along a fault, which has a downthrow of about 15 feet. The opening is in the St. Joe marble, which is jointed and shows considerable calcite. The ore is chiefly galena. Only a small amount of blende is found. This mine is interesting because of its being situated in the St. Joe limestone member, which is not usually ore bearing, and the fact that it is so at this place is undoubtedly due to crushing and displacement. The structure at this locality is apparently connected with a minor fault, which extends in a southeasterly direction, and is marked at several places by masses of brecciated Boone chert, which stand up above the surrounding rocks in bowlder-like forms. Such a mass was seen on the Dodd City-Harrison road, near the center of the section.

Markle.-This mine is situated in the SW. $\frac{1}{4}$ sec. 21, T. 29 N., R. 17 W., in what is known as Markle Hollow. At the time this mine was visited it was not being worked. The shaft is said to be 77 feet deep, and to have been sunk through broken limestone. A tunnel 50 feet long is driven into the side of the bluff, but was closed and idle. The ore was reported to be principally zinc blende, which occurs in a brecciated rock. 'The gangue is principally secondary chert, and this carries some galena. The principal amount of the ore came from 
the tunnel. A new shaft had been sunk to the ore-bearing horizon shortly before the mine was visited, and the ore on the dump showed galena and blende in a brecciated siliceous rock which apparently was originally a thin-bedded dolomite. There is considerable evidence of folding in this vicinity. The openings are just below the saccharoidal sandstone, which, together with the St. Joe, exhibits irregular dips in this locality. There is also evidence of minor faulting. A crusher and hand jigs (PI. XVIII, $B$ ) have been installed at this place, and considerable ore has been cleaned up and sold.

Pilot Rock.-This opening is in the NW. $\frac{1}{4}$ sec. 32 , T. 20 N., R. 17 W., in the valley of Sugarloaf, at the side of the Dodd City road. The principal working consists of a tunnel driven into horizontal dolomites. The country rock has been very largely replaced by secondary silica, and is brecciated, and exhibits small openings. The principal ore is blende. A large amount of carbonate is present. There is also tallow clay in the opening, and considerable evidence of the decay of the rocks in the alteration of the ore deposit. The opening is about 50 feet below the horizon of the Key sandstone, which, however, is not conspicuous at this place. The St. Joe limestone member is characteristically developed, and furnishes a more ready guide to the geologic position of the ore. It is interesting to note that the rocks are but little displaced or disturbed, and that the ore follows the bedding planes. The dip is low, and the relation of this mine to any definite structure is not at all clear.

Nakomis. - This property is located in a ravine tributary to Sugarloaf Creek, in the southern half of sec. 32, T. 20 N., R. 17 W. The rocks are Ordovician dolomites. The principal working which was examined was an open cut in the bed of the branch. At this place the ore is rather lean. A large amount of work had been done, and from the rock which had been stoped a bin of crush rock had been sorted. A shaft was being sunk at the mill, and lower down the branch prospecting with drill and the sinking of a shaft on a drill bole were in progress. Thus far no large ore bodies have been found, unless the reports of the drill records prove the existence of rich ore. A large mill and boiler house have been built on this property (Pl. XlX, $A$ ), and work was carried on steadily during the season.

Governor Eagle.-The location of this property is in the NW. $\frac{1}{4}$ sec. 7, T. 19 N., R. 17 W., in a valley tributary to Little Sugar Orchard Creek from the west, in which the Ordovician dolomites are exposed. The workings, which consist of two shafts, were inaccessible, since nothing has been done at this place for some time. The ore is zinc blende, which occurs in a coarse breccia and associated with pink spar. The rocks are reported to show, besides brecciation and fracturing, a slight displacement. The rocks which outcrop in this vicinity 


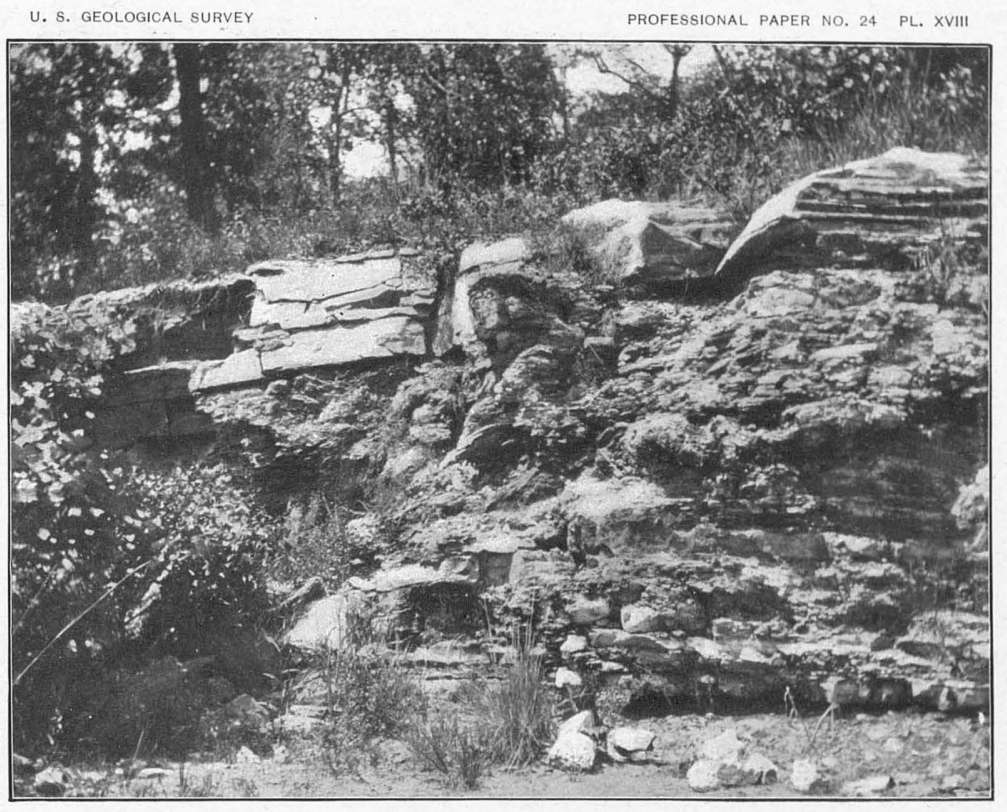

A. OPEN CUT IN BIG ELEPHANT MINE.

Key sandstone in upper part of exposure.

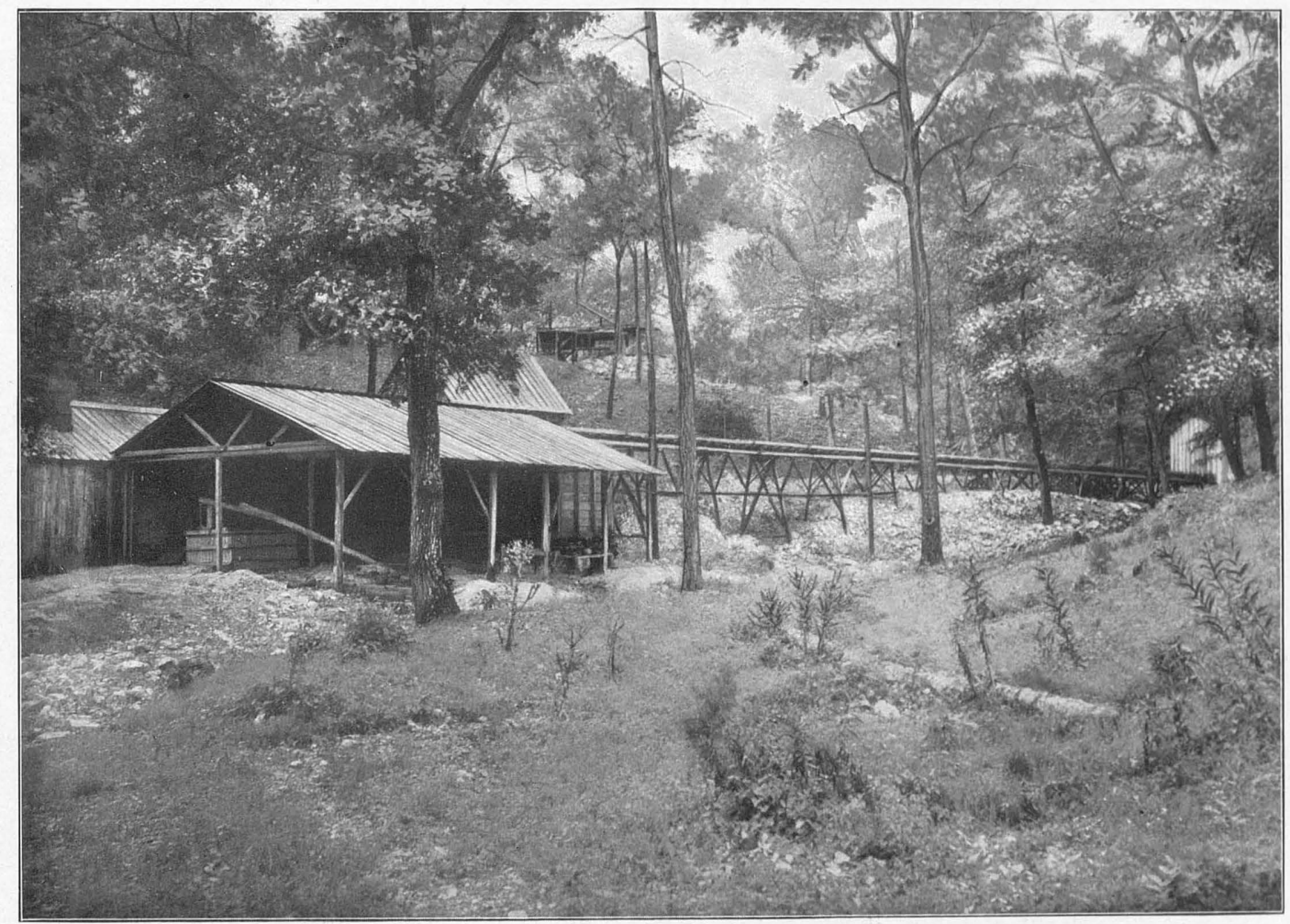

B. MARKLE MINE HAND JIGS. 



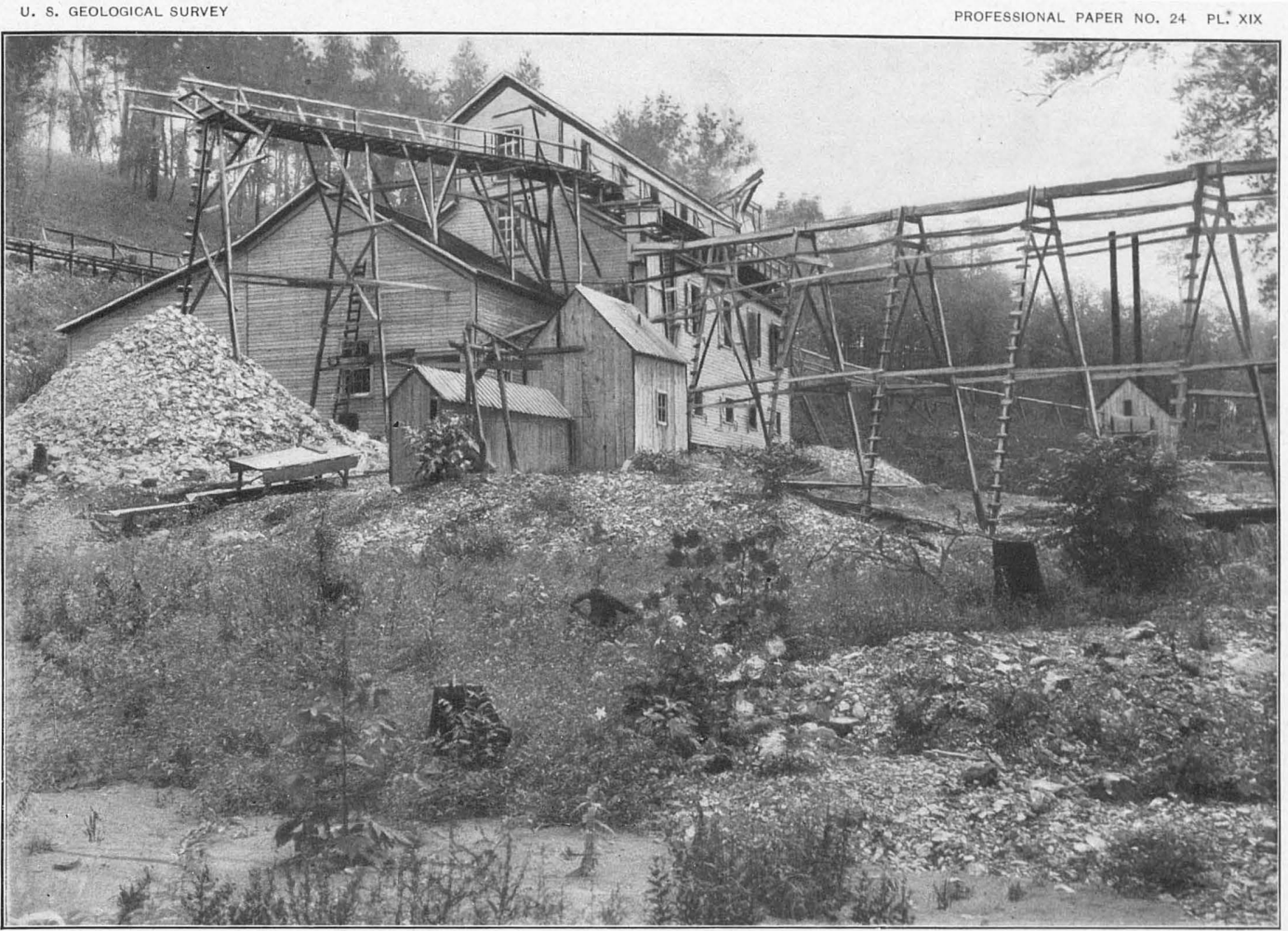

A. NAKOMIS MINE.

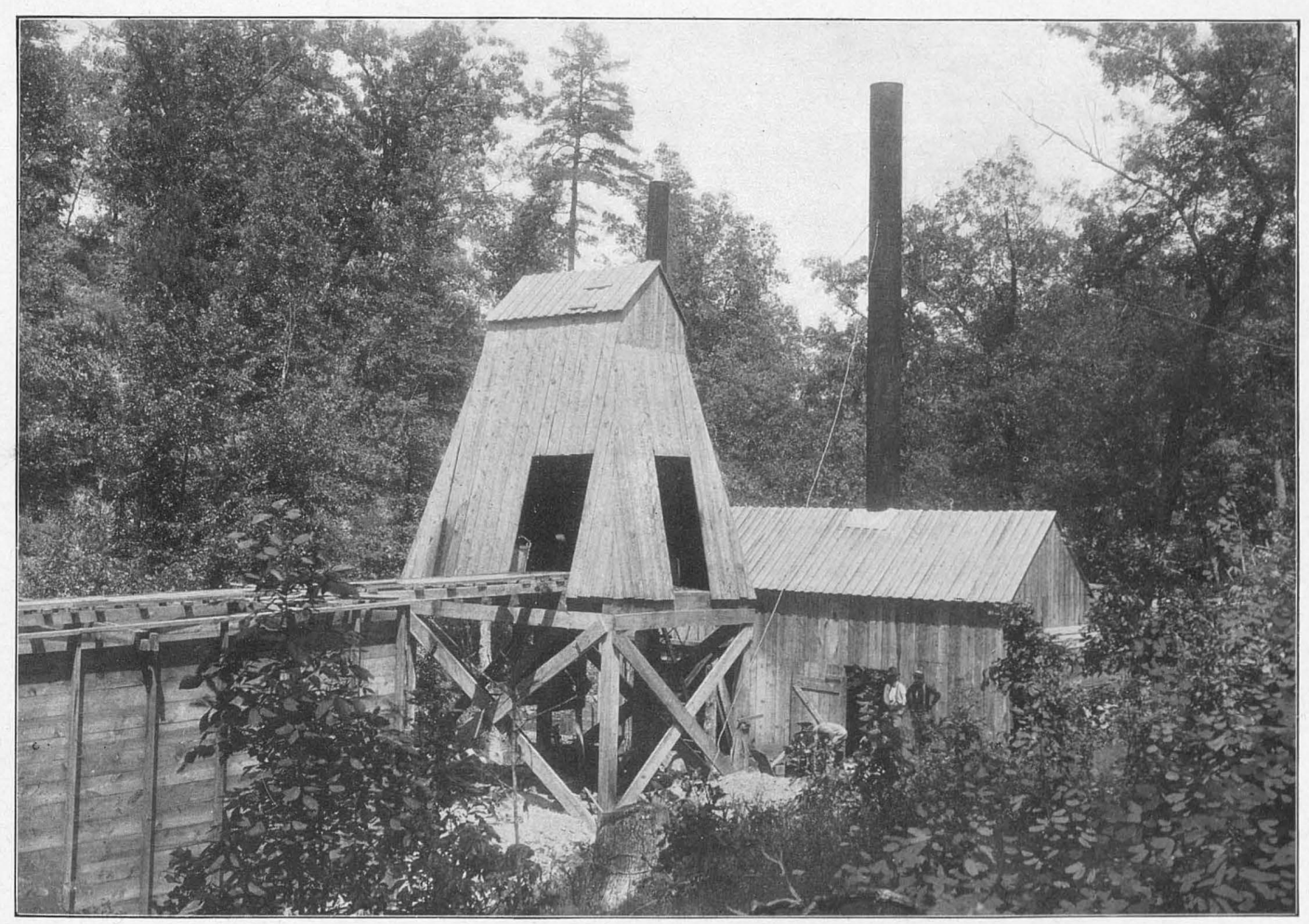

B. SUSqUEHANNA MINE. 

exhibit no definite dips or important undulations. The surface waters have altered the ore deposit to some extent, as is shown by the presence of carbonate and silicate ores and the weathered appearance of the dolomite crystals.

Susquehanna.-This property is situated in the eastern half of sec. 8, T. 19 N., R. $17 \mathrm{~W}$, on a small tributary of Little Sugar Orchard Creek. At this place a shaft has been sunk and shaft house and ore bin built (Pl. XIX, $B$ ). The ore is principally zinc blende associated with pink spar, and occurs in a brecciated dolomite. Considerable prospecting has been done lower down on Sugar Orchard Creek, and has shown the presence of ore at horizons varying from just below the Key sandstone down to the rocks exposed in the bed of the creek. "The Lemon and Layton prospect is one of the most promising.

Tarkiln.-This property is situated in the SE. $\frac{1}{4}$ sec. 10, T. 19 N., R. 18 W. The development work at this place includes a shaft, which was filled with water and therefore inaccessible when visited, and some open cuts. The ore is principally blende, with some carbonate and silicate. The crush rock found on the dump was rich. Not enough work has been done here to show the extent of the deposit. The ore horizon is immediately below the Key sandstone. The rocks in this locality exhibit variation in dip, and show fracturing and jointing and some brecciation.

Bear Hill.-This property is located in the southern half of sec. 11, T. 19 N., R. 17 W. The main shaft is in the upper part of the Ordovician dolomites, the mouth of it being about 40 feet below the St. Joe member of the Boone formation, which is well exposed near by, and at a somewhat less distance below the Key sandstone. A small mill and shaft house have been built (Pl. XX, $A$ ), and a crusher and hand jigs installed, but no work has been done for several years, although the mine has produced considerable ore. The main shaft is reported to be 157 feet deep, and drifts have been made at various depths. The ore which was seen at this mine was found in a breccia, and in material which apparently filled fractures. It consisted principally of blende.

Batie.--This property is near the center of sec. 1, T. 19 N., R. 17 W., and consists of openings made in the bed of Jimmie Creek. The ore found in the Ordovician limestone is about 75 feet below the Key sandstone. The rocks have been quarried and blasted, exposing the ore deposit, which apparently follows the bedding. A shaft has also been sunk, but was filled with water, so that it was inaccessible. The ore seen on the dump was apparently taken from this shaft. In these openings the principal ore is zinc blende, though some carbonate and silicate ores were found. The structure which appears to determine the position of the ore is brecciation. The matrix is to a large degree siliceous. and exhibits 
infiltration of sand grains and deposition of calcite and pink spar. By quarrying, a large quantity of ore can be obtained at this place without underground workings.

Big Elephant.--These workings (PI. XVIII, $A$ ) are in the NE. $\frac{1}{4}$ sec. 30, T.

20 N., R. $16 \mathrm{~W}$. The ore deposits at this place are apparently related to a siliceous deposit which extends from the St. Joe member of the Boone formation down to the horizon of the Key sandstone. Dolomite spar is found in the lower beds. The principal ore is zinc blende, which occurs associated with the chert. It has, however, been largely altered by surface decay, and the rock which originally contained it has a cellular structure where the ore has been dissolved out. Considerable carbonate also occurs as a result of this alteration. In the upper part, in the St. Joe limestone member, there is considerable lead ore, which likewise shows alteration to carbonate. This mine has interesting structural features, and the position of the ore body is one which is unusual in the district. The fact that the Key sundstone is thin at this locality perhaps accounts for the continuity of the ore deposit from the Carboniferous into the Ordovician.

Big Buffalo.-At the intersection of some deep ravines in the southeastern border of sec. 5 , T. 19 N., R. $16 \mathrm{~W}$., there are a number of openings which show a deposit of ore related to the bedding of the rocks. The horizon is in the upper part of the Ordovician. The ore-bearing strata have been largely replaced by secondary chert, and exhibit thin bedding. In some places they have been brecciated, while in others their original structure is maintained. The blende has been dissolved out near the surface, or adjacent to the water channels, leaving the matrix with a honeycombed appearance. The effect of this solution has also been to convert the blende into carbonate and silicate, which is found as a coating on the ore and rocks. This deposit, although, unfortunately, but a few inches thick, is singularly continuous and fairly rich. Another run is reported 12 feet above the typical one, and is said to be similar in character to the lower. Prospecting was being carried on at the time the property was visited, in the hope of finding a workable face of ore.

Olympia.-On Jimmie Creek near the mouth of Moccasin Creek a new townKingdon Springs-has been established. In this vicinity a number of drill boles have been sunk and considerable prospecting done. Fourteen of the drill records were charted, for the purpose of showing the thickness of the ore deposits reported by the driller. The statement is made that the ore occurs in disseminated deposits of exceptional thickness. At the time this locality was visited no workable deposit had been opened. On a tract of land where four drill holes had been sunk the Olympia shaft was being put down in order to determine the nature of the bodies of ore which the driller reported. Considerable difficulty was experienced in sinking this shaft, since a strong flow of water was 


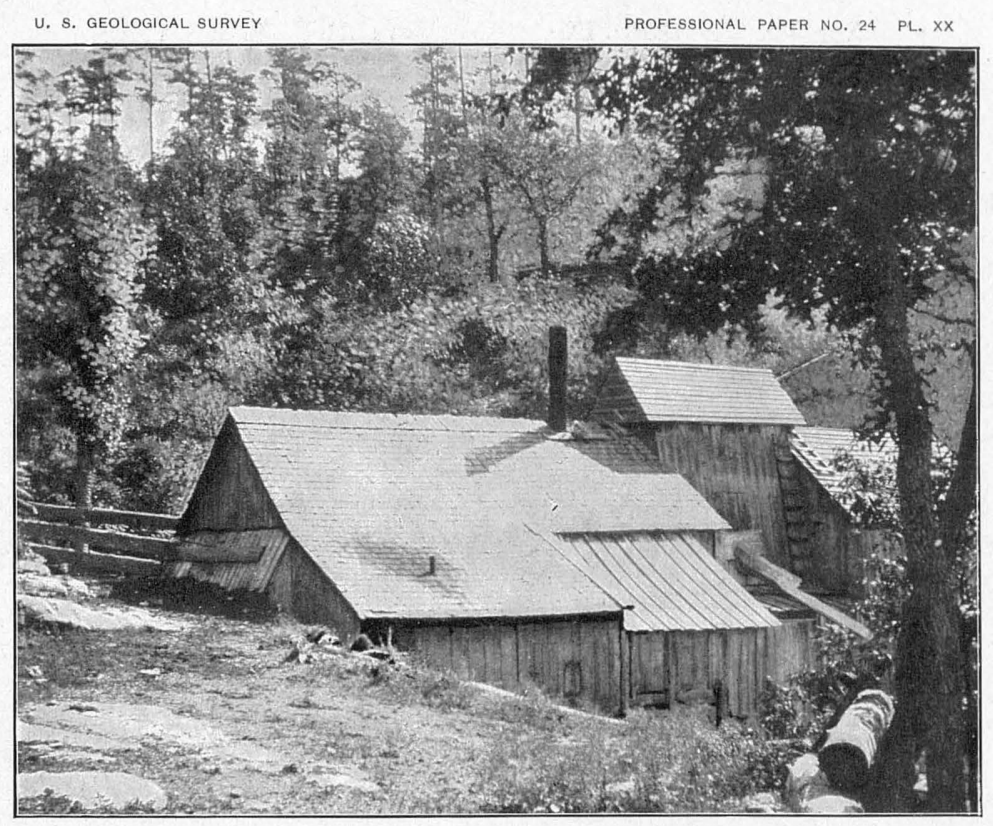

A. BEAR HILL MINE.

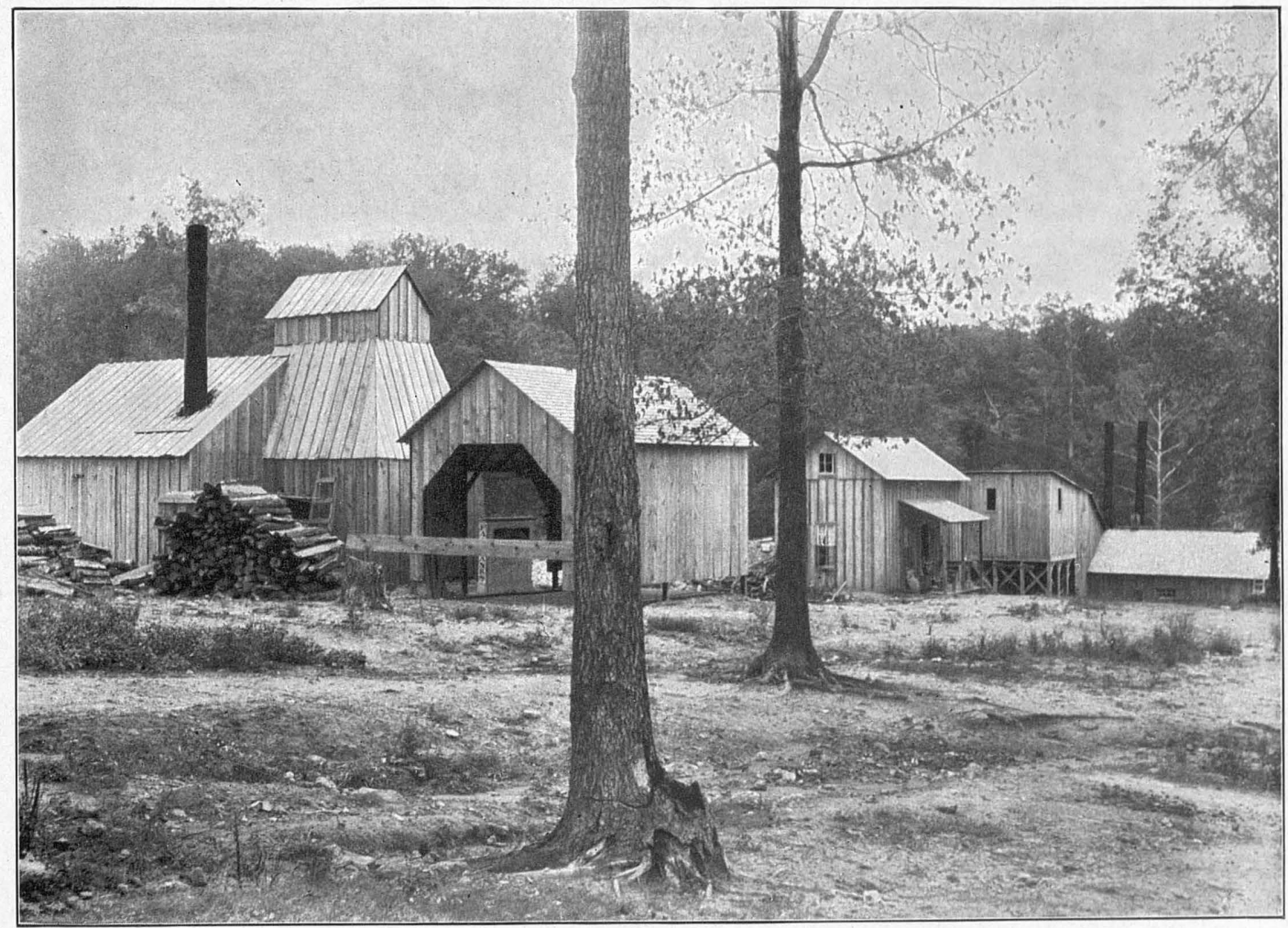

B. BEULAH MINE. 

encountered. When last visited it had reached a depth of about 100 feet, and had passed through what was known as the upper run of ore. It was expected to reach a lower run in a short time. The rock upon the dump was dolomite, but slightly altered in any way, with the exception that it was more or less siliceous, and exhibited fracturing and cavities lined with quartz crystals. Some of the beds are probably brecciated. But little pink spar was found. The mouth of this shaft is approximately 300 feet below the horizon of the Key sandstone, and is, accordingly, geologically much lower than most of the openings which have been made in the district. The results of this prospecting, when fully determined, will have an important bearing upon the depth at which ore bodies may be found in the Ordovician. The nature of the rock, which is characterized by quartz druses, is not encouraging, although some beautiful specimens of ruby jack were found in pockets.

North Star.-This opening is in the eastern part of sec. 9, T. 19 N., R. 16 W. It consists of an open cut which has been extended along the hillside just below the Key sandstone. The rocks are the Ordovician dolomites, somewhat siliceous and showing infiltration of sand grains. The opening does not extend far into the hill. The rocks show the results of surface decay, and the ore deposits have been leached and altered to carbonates. The ore on the dump contains a large amount of carbonate, although the original deposit was plainly zinc blende, a considerable amount of which has been dissolved, as is shown by the cellular structure of the rocks which preserve the casts of the crystals. The rocks in this locality show some undulation, although no definite dips could be made out. The beds are jointed and have been considerably fractured. An interesting feature of this deposit is the fact that some blende has been deposited on the saccharoidal sandstone where it has been jointed and slightly displaced.

Summit Home.-This prospect is located near the center of sec. 15, T. 18 N., R. $15 \mathrm{~W}$., near the summit of the divide. The rocks are nearly horizontal, bluish dolomites. The ore horizon is well toward the upper limit of the Yellville formation. The beds are considerably fractured and brecciated. The ore is mixed carbonate and silicate, with some blende. Five open cuts at about the same level constitute the workings. From 5 to 7 tons of ore-bearing rock have been thrown out of each eut, and a little more is still in sight in the walls of several of the openings.

Dyson.-In the SE. $\frac{1}{4}$ sec. 30 , T. 18 N., R. 15 W., a considerable exposure of a brecciated deposit has been made by quarrying and drifting. This property is situated well up on the hillside, and the ore-bearing bed is near the top of the Ordovician dolomites. A large pile of crush rock was on the dump, and it was reported at the time the property was visited that a mill was to be erected. 
The ore body is clearly related to the bedding of the formations, and is found in a stratum which has been coarsely brecciated. The cementing material of the breccia is pink spar, which is rather abundant. From the appearance of the faces of the openings the deposit has a tendency to run rather irregularly as regards richness, in some cases very little blende appearing with the pink spar. Although this property is a promising one, in view of the fact that workings show lean ore in certain faces, it is probable that the percentage will vary considerably from place to place as the bed is worked into the hill and along its face. This will necessitate judicious methods of cutting the ground.

Bald Jesse.-This opening is well up near the top of the mountain called Bald Jesse, situated in the $\mathrm{NW} . \frac{1}{4}$ sec. $25, \mathrm{~T} .18 \mathrm{~N}$., R. $16 \mathrm{~W}$. In ascending the eastern slope of this mountain thick beds of brecciated dolomite are conspicuously exposed where the surface is bare of soil and vegetation. The prospect which is here described is at a place where such a breccia is mineralized. The openings are about 50 feet below the horizon of the Key sandstone. Not very much work has been done, and, accordingly, the value of the ore body has not been determined.

Hawkeye-On the east side of Clabber Creek, in sec. 4, T. 17 N., R. 15 W., a brecciated bed has been squarried in the hillside about 75 feet above the creek bed, and shown to carry a considerable amount of zinc blende associated with pink spar. This property is located on a very characteristic bed of breccia, which is continuous for a considerable distance, as is shown by the following prospects.

Starlight.-This opening is to the south of the Hawkeye and apparently in the same geologic horizon.

Eldorado.-The breccia, which is continuous from the Hawkye to the Starlight, dips slightly to the south, so that at the Eldorado it is lower in the bluff of Clabber Creek. At this place it carries considerable zinc blende, but the amount varies along the bed.

Beulah.-At the Beulah (PI. XX, $B$ ) the original openings were made just above the level of Clabber Creek, and probably at about the same geologic horizon as the ore deposits in the Hawkeye, Starlight, and Eldorado. The ore in some places is a rich deposit of zinc blende associated with pink spar in coarse breccia. It was found at several openings, and drill holes report it at other places on the property. A large mill was erected for the purpose of concentrating the ores, and a working shaft was sunk and connected with the mill by overhead tramway. From the exposure of the ore near the creek bed a tunnel was driven to the working shaft, a distance of about 250 feet, the most of which was through barren rock. This tunnel was driven on a level, and it may be that the ore 


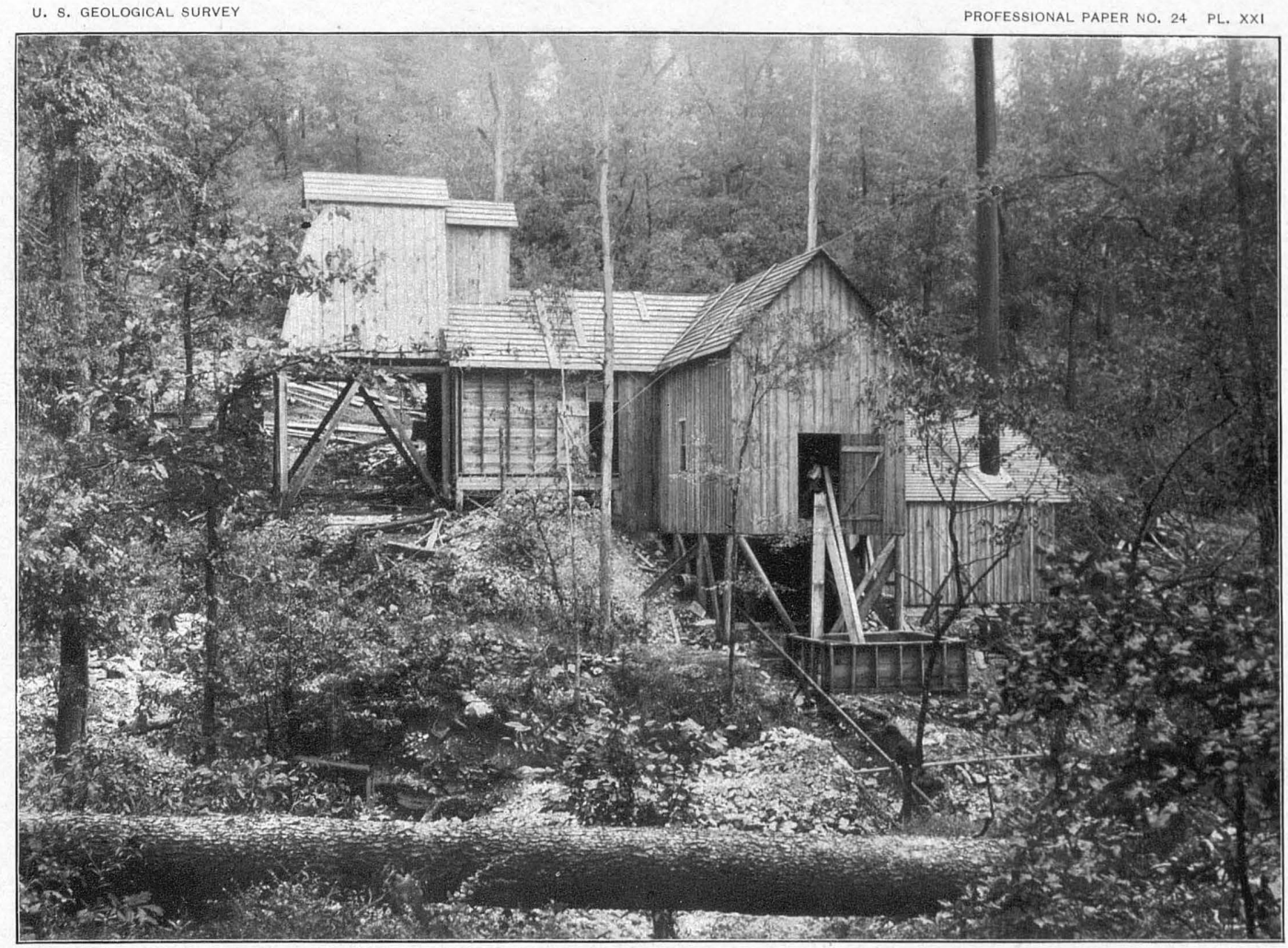

A. CLIMAX IMINE.

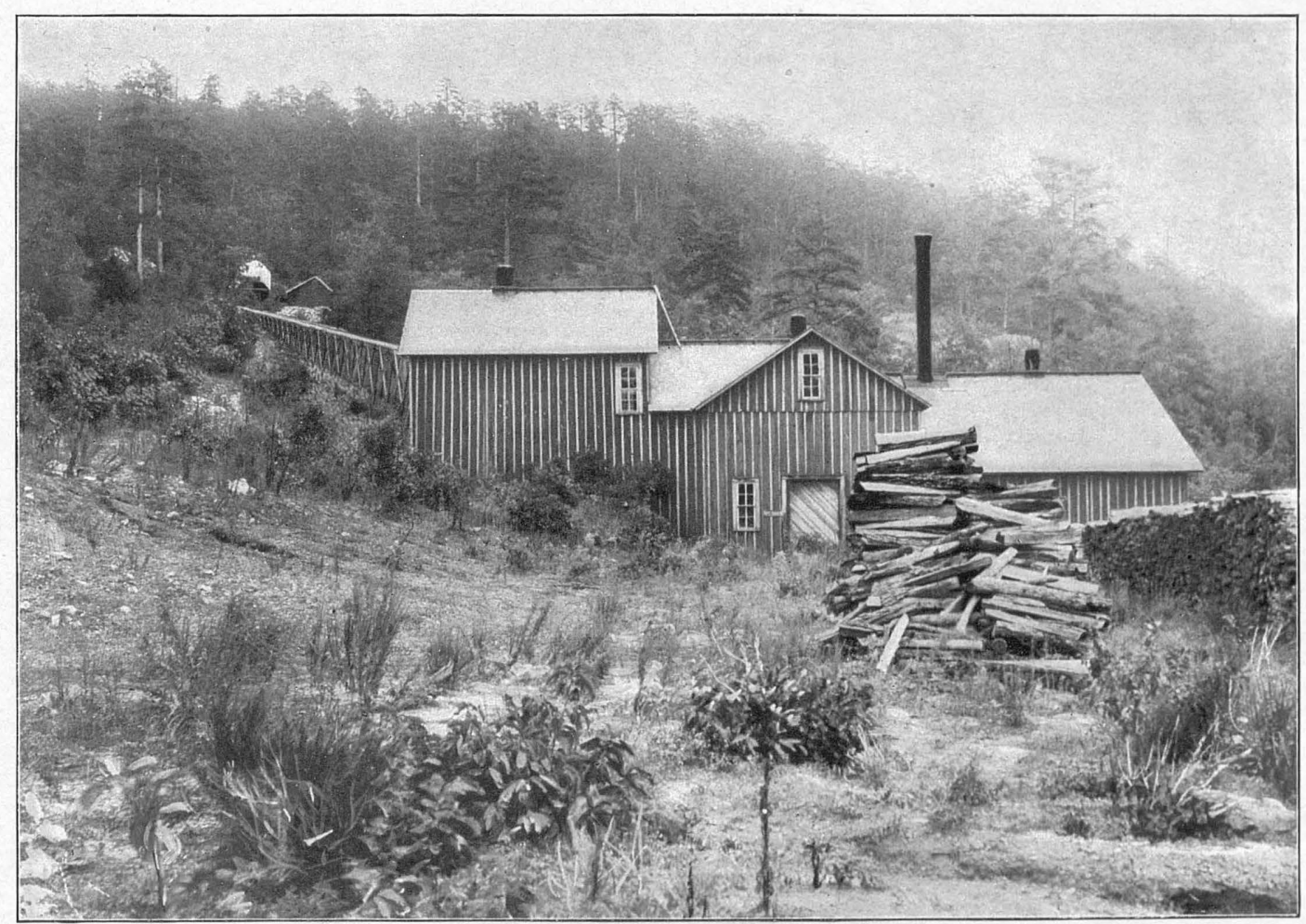

B. MORNING STAR MILL

Connected with mine above by gravity tram. 



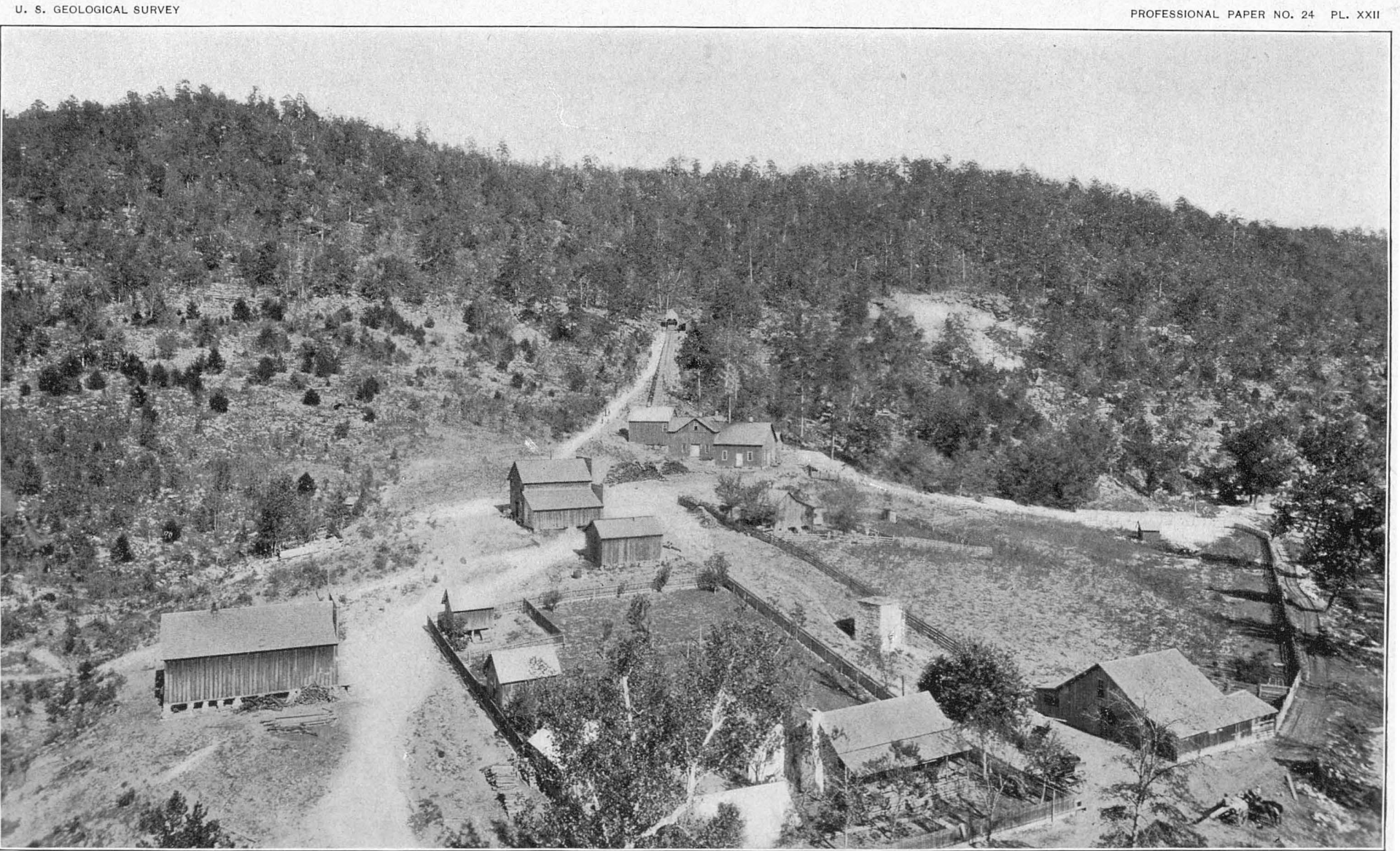

VIEW OF RUSH POST-OFFICE AND MORNING STAR MINE AND MILL.

Courtesy of Mr. Bryan Snyder, general passenger agent St. Louis and San Francisco Railway. 

deposit dips at this place, so that the tunnel passed out of the ore. From an examination of the workings, however, it was apparent that the brecciation is frequently localized, and the ore deposits first encountered extend but a short distance before showing considerable variation, apparently as a result of the change in the structure of the rocks. Some ore has been milled from this mine, but the works are now idle.

Zinc Basin.-The Zinc Basin prospect, which is situated in the SW. $\frac{1}{4}$ sec. 3, T. 17 N., R. 15 W., was newly opened when visited. It is on a brecciated bed very similar to that which is exposed at the Beulah. It is only a few feet above the level of the water in Clabber Creek. The second opening was being started near by. The ore at this place is zinc blende. An interesting feature at this prospect was the occurrence of a small amount of mineral pitch, which seemed to be developed in the rocks which contained organic matter. The dolomite at this place exhibits thin films of dark, carbonaceous material along the planes of sedimentation. This has a bearing on the deposition of the ore, the familiar statement of the precipitation of sulphide as a result of the presence of organic matter seemingly being verified in this instance.

Climax.-This property (PI. XXI, $A$ ) is in the NE. $\frac{1}{4}$ sec. 1, T. 17 N., R. 16 W., on a small tributary of Rush Creek. The openings are in the Ordovician limestones, a few feet below the Key sandstone, and consist of open cuts in the bed of the branch, and a working shaft at the mill. The ore found was principally blende, although some carbonate appears near the surface. The deposit is in a breccia, and fracturing is also plainly seen at this place. Just east of the workings a fault having a throw sufficient to bring the Boone chert down to a level with the Key sandstone can be readily seen on the south side of the branch where the sandstone ledge is discontinuous. This fault is apparently a minor one, parallel to the main Rush Creek fault, elsewhere described. No work has been done which shows whether or not mineralization has occurred along it. At the time this property was visited the mill had been newly erected, but no ore had been milled, and sufficient work had not been done to determine the extent of the ore body.

Morning Star.-This property is situated on the north side of Rush Creek, 150 feet above the level of the stream, near Rush post-office, in the NW. $\frac{1}{4}$ sec. 10, T. 17 N., R. 15 W. The workings consist of open cuts, all on about the same level. A gravity tramway has been laid in the principal workings, and an incline constructed to the mill, which is situated on the hillside below (PI. XXII). This mine has produced considerable ore, which is shipped by way of White River to Batesville, and thence by railroad. The mill (PI. XXI, A) was built in 1898, but has not been operated since 1900 . The ore in this mine, which has made it cele- 
brated, is a rich carbonate, which occurs in several forms. At present the principal ore shown in the workings is zinc blende, although a large amount of carbonate is associated with it. The workings are all related to what appears to be a fissure or fracture parallel with the main Rush Creek fault. There are minor faults and fractures and brecciation observable. With the exception of some of the minor faults the amount of displacement can not be estimated. It probably does not amount ta many feet, and is a subsidiary feature of the displacement which has taken place along the main fault. The country rock is a dolomite, and there is both secondary chert and pink spar associated with the ore. A yiew of the largest opening is shown in Pl. XXIII, $A$. The tract is seen entering opposite the fissure above mentioned. To the left is an irregular drift, in the walls of which rich ore is seen. To the east of the fissure, as here exposed, some shallow pits have been sunk which expose the material filling the fissure, and give reason to believe that it is continuous for some distance along the hillside. This mine is not only interesting because of the rich deposit which it discloses, and the association of original and secondary ores, but because of the structure which can be made out. Similar relations no doubt exist in other localities, but the fissures are seldom so conspicuous, although they have evidently played the same rôle in the processes of ore deposition, by determining the circulation of the mineral-bearing solutions. The deposition of the secondary ores appears plainly to be the result of the leaching of the sulphides by surface waters and the redeposition of them as incrustations, principally as carbonate in stalactitic form, or as coatings upon the rock, and in some cases replacing the rock material.

McIntosh.-This mine is in the SE. $\frac{1}{4}$ sec. 10 , T. 17 N., R. 15 W., adjoining the Morning Star, and on the same hillside. The ore apparently occurs in the same horizon. It has been mined principally in an open cut and drifts from this cut. No fissure and no definite system of fractures could be made out at this place. It is approximately in line with the fissure at the Morning Star, which if it continues as far as the McIntosh, is disguised in the billside by the débris of the slope (Pl. XXIV). In addition to the upper openings, some prospecting has been done on a level with the creek, and has resulted in the finding of a breccia carrying zinc blende in a matrix of pink spar. This ore all resembles, in a way, that in the breccia at the Beulah and Zinc Basin, which occur at approximately the same elevation on the north side of Rush Creek Mountain.

White Eagle.-This mine (Pl. XXV, A) is in the NW. sec. 11, T. 17 N., R. $15 \mathrm{~W}$., in bottom land adjacent to Buffalo Fork just below the mouth of Rush Creek. The mine consists of a shaft 65 feet deep and a drift run from the bottom of the shaft. The ore-bearing rock is a siliceous replacement of the dolomites, and, although somewhat different from the deposit at the Morning Star 


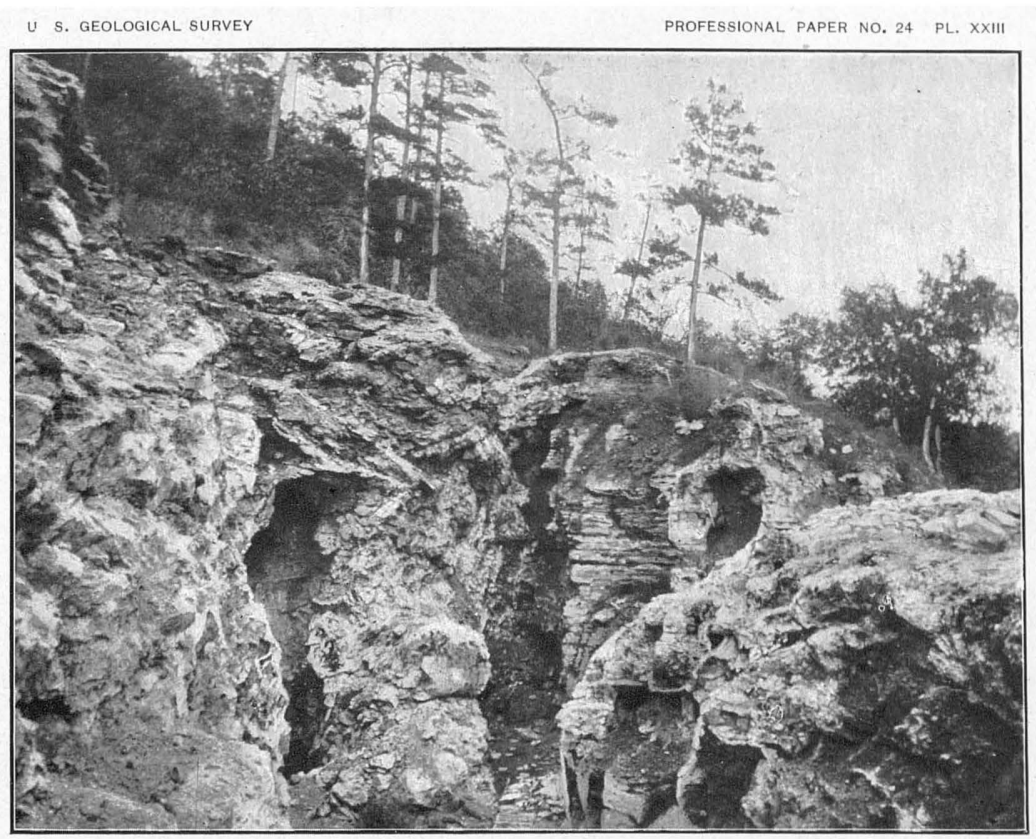

A. EAST END OF MAIN CUT AT MORNING STAR MINE, SHOWING FISSURE OPPOSITE END OF TRACK.

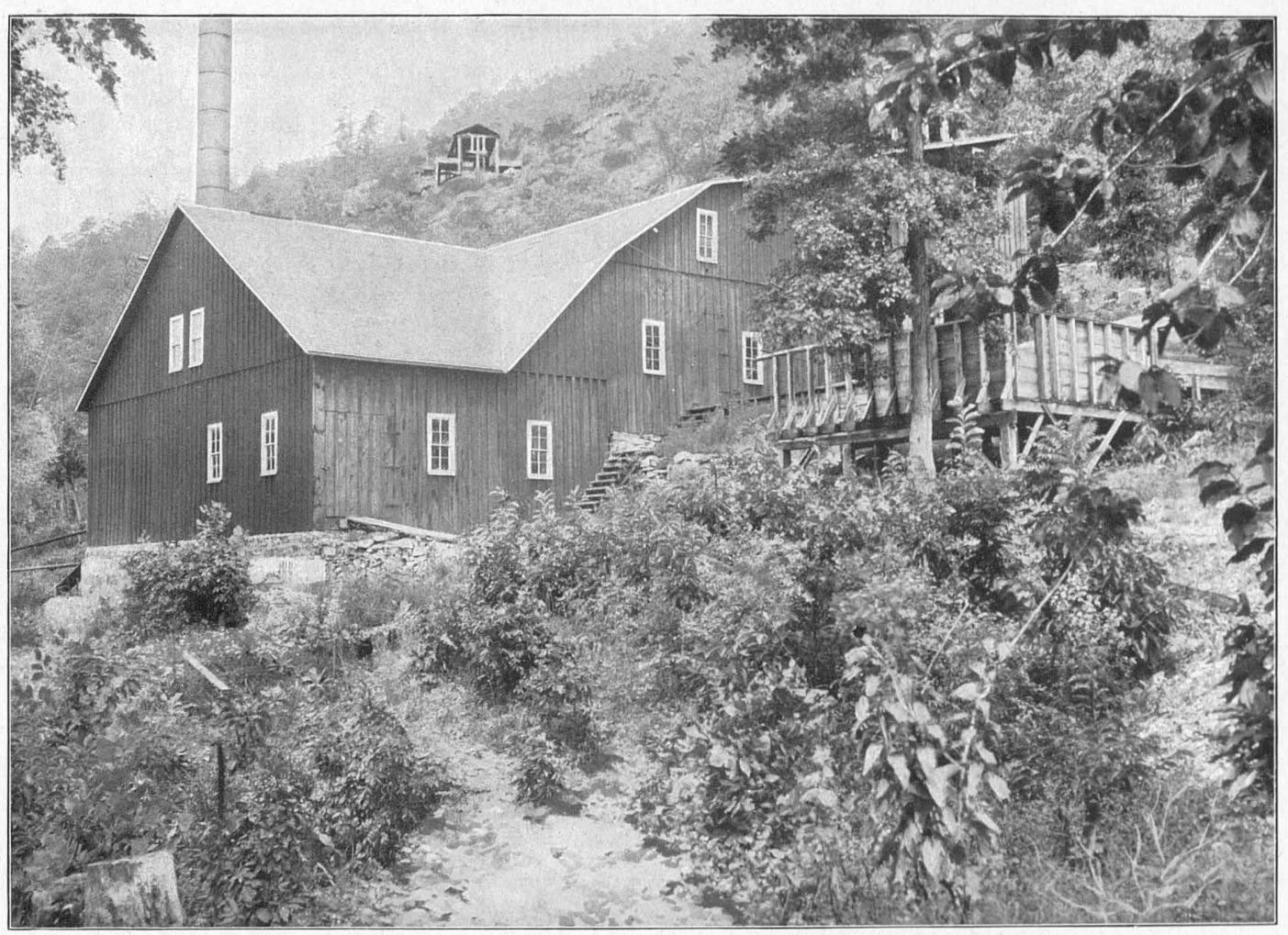

B. MCINTOSH MILL.

Connected with mine above by cable tram. 



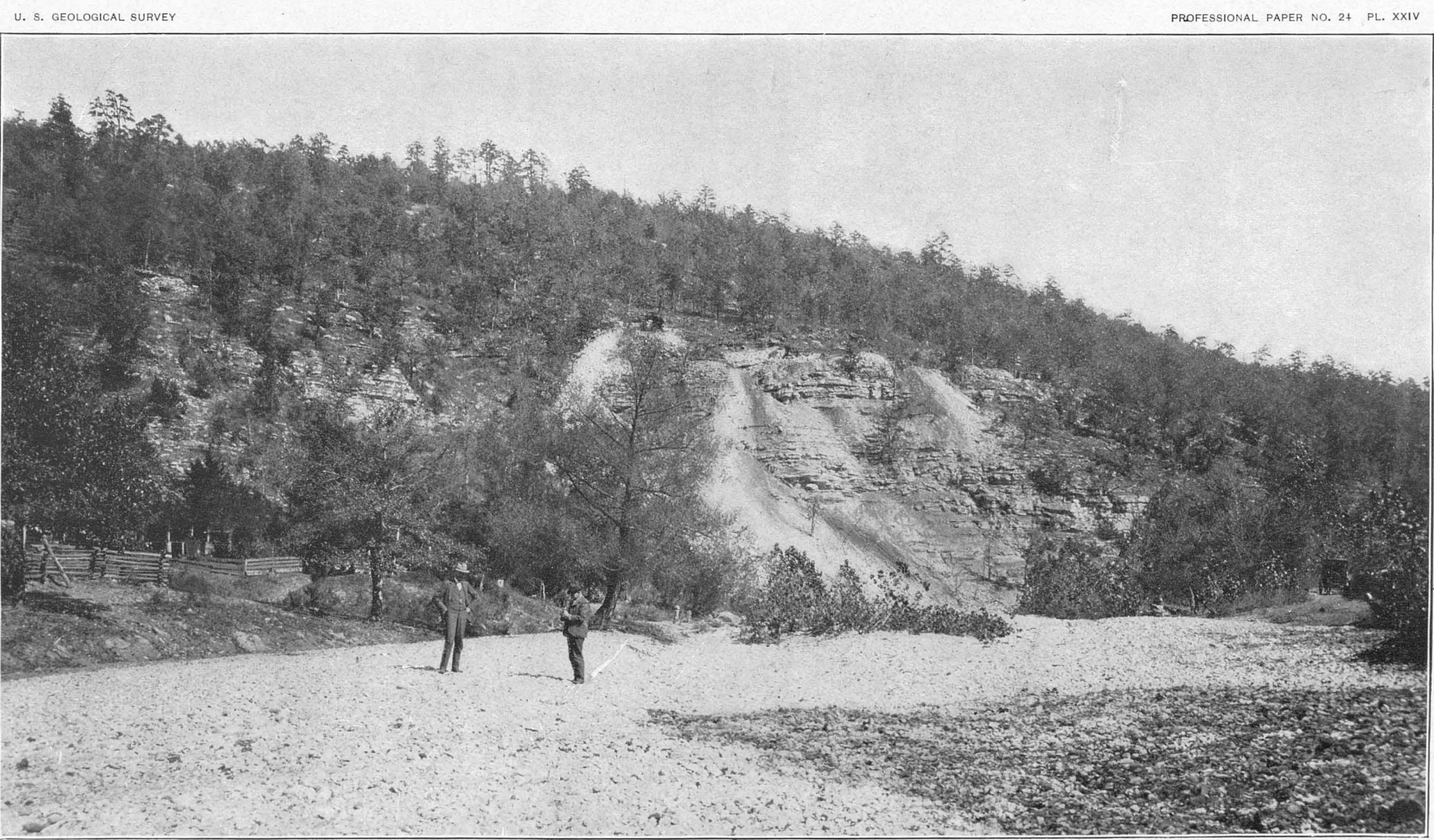

MCINTUSH MINE, RUSH, ARK., SHOWING NATURAL EXPOSURE OF ROCKS SOMEWHAT OBSCURED BY WASTE FROM THE OPEN CUT. Courtesy of Mr. Bryan Snyder, general passenger agent St. Louis and San Francisco Railway. 

and McIntosh, it is believed by some to occur at the same geologic horizon, but at a lower elevation as a result of the dip. It was impossible to verify this by identifying the individual beds which outcrop at intermediate places; but it is not improbable that the mine is in the same general horizon, although the occurrence of ore deposits at varying horizons makes it a doubtful and unimportant point. At the time this mine was visited no work was being done and none had been carried on for some time. It was, accordingly, filled with water and inaccessible. From an examination of the ore upon the dump it was seen that there is associated with the deposit considerable quartz as coatings of small crystals on free surfaces. Not much pink spar was observed. Calcite, however, occurs interestingly at this place. A large mass of doubly terminated scalenohedral crystals was shown to the writer, which was reported to have come from a cave-like opening in the mine. Considerable conjecture and discussion has been indulged in by those who have visited the property, as well as those interested in it, as to whether the Rush Creek fault passes through this ground and as to whether the ore deposit is related to fissures. In the absence of an examination of the workings nothing could be determined definitely on this point.

Maryhattiana.-On this property considerable prospecting has been done in the bed of the creek and on the hillsides. The ore occurs in brecciated dolomite, and the rocks show some faulting and slight folds or waves. The vicinity is promising and of considerable interest, because it is situated south of the Rush Creek fault. The occurrence of ore along this creek shows that the ore bodies are not confined to the vicinity of the main faults.

Red Cloud.-This opening (Pl. XXV, B), which consists of a large open cut on the hillside on the east side of Buffalo Fork opposite the mouth of Rush Creek, is in the NW. $\frac{1}{4}$ sec. 14, T. 17 N., R. 15 W. It is about 70 feet above the level of the river, and extends for approximately 100 feet along the bluff, It is a shallow stripping and exposes rich deposits, the ore consisting principally of zinc blende, which is found associated with secondary chert and pink spar. In places where the deposit is especially rich it replaces the adjacent country rock. The structure at this mine is obscure. The relation of the deposit to others in this locality was not satisfactorily made out. The Rush Creek fault, which is in most places easily traced, should strike across Buffalo Fork somewhere near the mouth of Rush Creek. The throw of the fault near Rush post-office is about 350 feet. It undoubtedly is less at many places, and apparently the displacement is taken up by irregular structure and diminishes before reaching Buffalo Fork, since it was not possible to locate the fault on the east side of that stream. The rocks in 
the Red Cloud mine show some dip to the north, but it is slight and is not apparently, associated with any faulting.

Silver Hollow.-This mine is in the NW. $\frac{1}{4}$ sec. 13, T. 17 N., R. 15 W., in the face of the south bluff of Buffalo Fork of White River. The lower opening, which is about 20 feet above the level of the river at its ordinary stage, is in a brecciated bed which carries a rich deposit of zinc blende, especially near the beginning of the tunnel. Near the surface the ore has been altered to zinc carbonate. The original deposit is clearly related to the bedding of the rock mass, zinc blende occurring in a secondary chert and with pink spar. The tunnel has been driven for a considerable distance, and has passed into barren ground. The faces of the earlier workings still show good ore. The development thus far indicates the localization of the ore bodies in a manner which is not uncommon through the district, the position seemingly having been determined by fracturing of the country rock. The upper opening, which is about 50 feet higher in the bluff and about as far to the southeast, is an open cut in which, work was in progress at the time the mine was visited. The ore body there has the appearance of occurring in a fissure. This is suggested by the difference in the character of the rock on the two sides of the opening and by the shape of the ore body. It was impossible, however, to ascertain whether this is the case, since in the newer working the limits of the ore body have not been reached and there are no satisfactory exposures on the bluff. The ore in the upper opening consists of zinc blende and zinc carbonate, associated with which is a large amount of pyrite. This is the only deposit seen in northern Arkansas where pyrite is abundant or associated with zinc in quantities which impair the commercial value of the mine. The oxidation of the pyrite and zinc blende has given rise to limonite and zinc carbonate. On the botryoidal surfaces the zinc carbonate is beautifully stained by the iron. Ore which carries such a large percentage of pyrite can not be cleaned satisfactorily by the ordinary process of jigging, since the specific gravity of the two minerals is so nearly the same. In order to prepare this ore it will be necessary to resort to a process of roasting and rejigging, or magnetic separation. By roasting the ore the pyrite is deprived of a certain amount of its sulphur and is rendered relatively lighter.

The lower opening in Silver Hollow is free from pyrite. Thus far the workings do not show the relation of the two ore bodies. If the upper oneoccurs along a fault zone it is probable that the lower one is related to this structure. Future developments may demonstrate this, or show that the two masses have been independently segregated.

Boat Creek.-This mine is near the mouth of Boat Creek, in the center of sec. 7, T. 17 N., R. 14 W. The ore deposit consists of zinc blende, occurring 


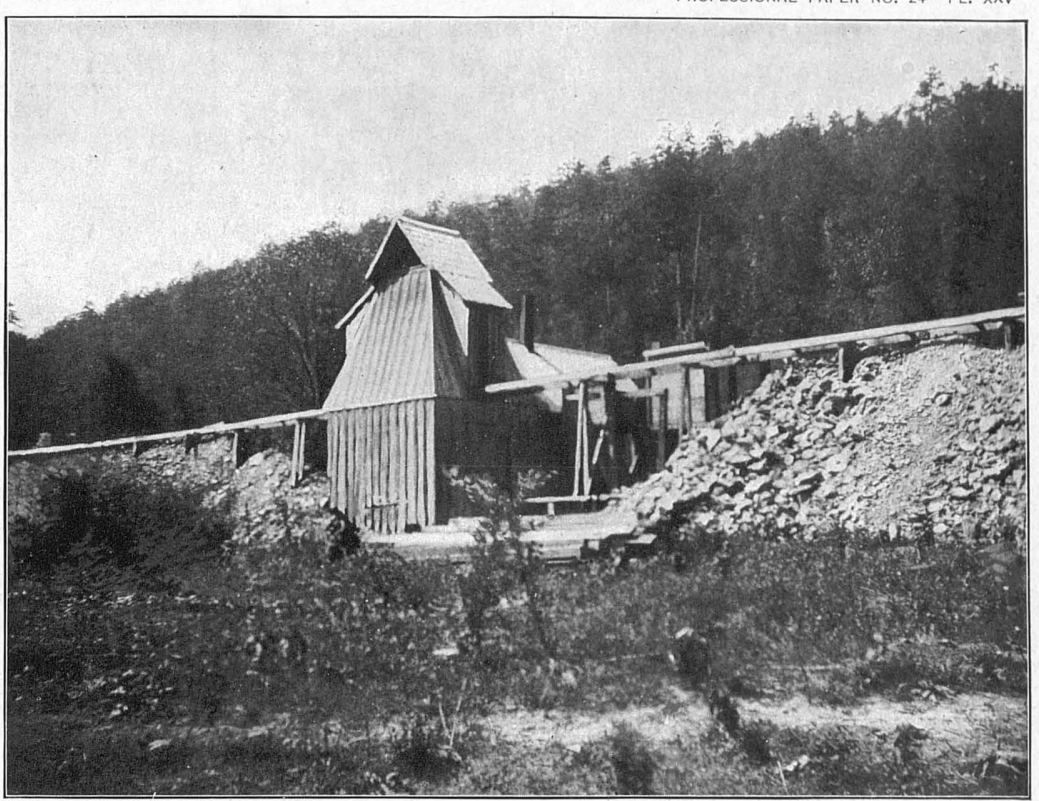

A. WHITE EAGLE MINE.

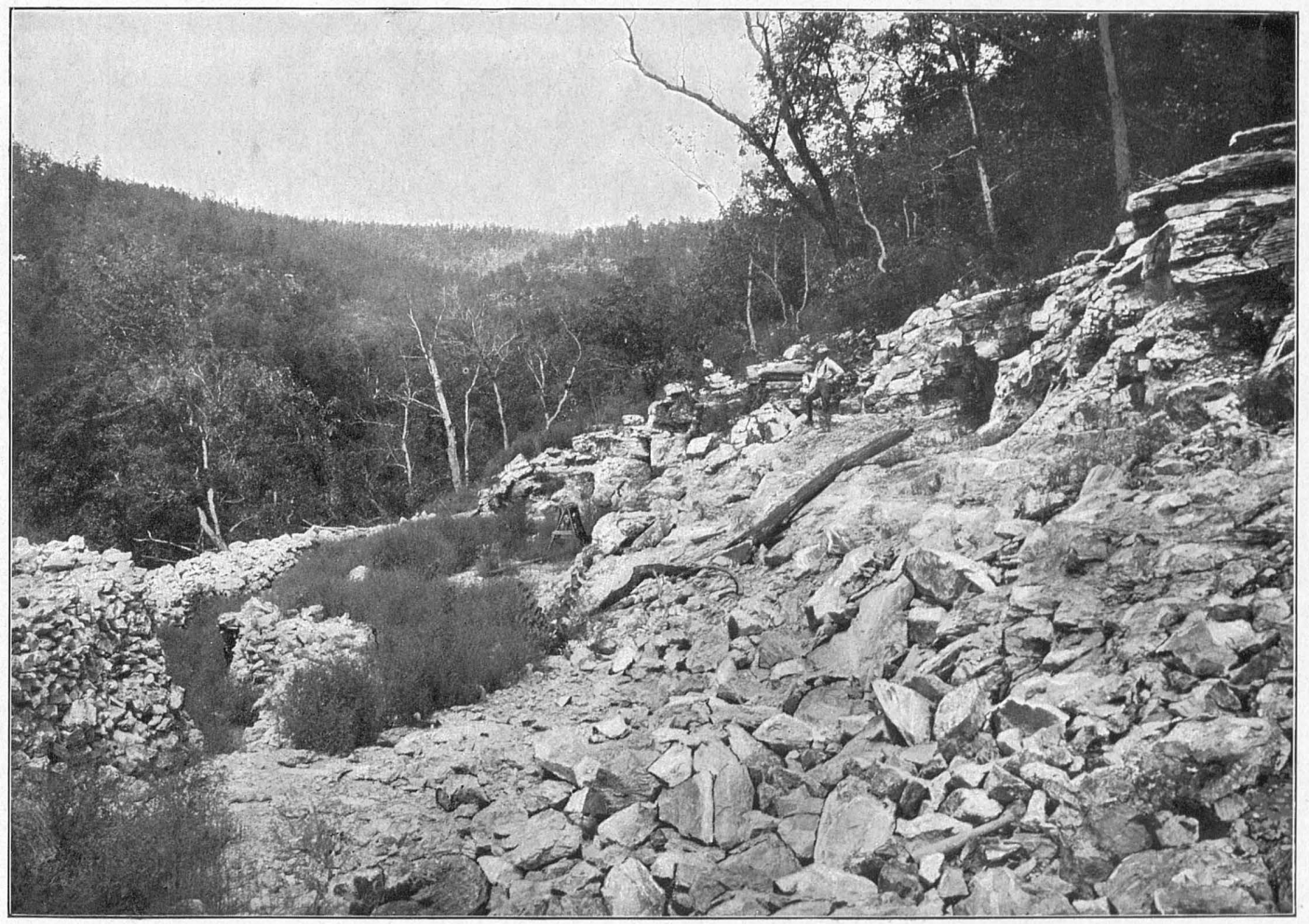

B. RED CLOUd MINE. 

in rich masses associated with pink spar and replacing dolomite. Here, as in other places in the district, in the process of ore deposition there has been produced what is sometimes referred to as disseminated blende. This term is used by the prospectors in northern Arkansas to designate ore which is found in small crystals and masses in the country rock. The process of formation is not an unusual one, and may be more appropriately described under the name of replacement. The ore-bearing solutions which gave rise to the ore occurring in the open spaces associated with pink spar in a breccia also dissolved the adjacent country rock and precipitated crystals of blende in the place of the material extracted. This apparently has occurred where the solution was rich in zinc, as is attested by the fact that the ore in the breccias occurs in large masses. The Boat Creek deposit is related to the bedding of the rocks, and the same horizon is demonstrated to be ore bearing at other places near by.

Sam Hill.-This prospect, which is immediately below the Key sandstone, and consequently near the top of the Ordovician beds, is of interest here as showing the vertical range of the ore bodies. It is situated in the SE. 1 sec. 13, T. 17 N., R. $15 \mathrm{~W}$., about 500 feet above the level of Buffalo Fork. It is accordingly nearly 300 feet above the Boat Creek mine, and over 300 feet above the Silver Hollow. The ore at the Sam Hill mine occurs in brecciated and fractured dolomite. The workings thus far are in rocks which show the action of surface waters, and accordingly there is present a large amount of silicate and carbonate, although the original deposit was plainly zinc blende.

Bonanza:-On Cow Creek, in the SE. sec. 10, T. 17 N., R. 14 W., the Ordovician rocks have been extensively brecciated, and the displaced fragments, which vary in size up to several inches in length, can be seen in the weathered exposures of the beds on the hillsides at many places. Brecciation has occurred at several horizons. The Bonanza opening is in such a bed, where the ore deposits for some reason have been localized. The working consists of an open cut in a shaft which has demonstrated a workable body. The ore consists of zinc blende associated with pink spar, sometimes occurring in large masses. It has been altered to loose secondary deposits of carbonate and silicate. On this property a core drill has been used in prospecting. It is a light, portable machine, which cuts by means of chilled shot, and with it it has been possible to pass through the open ground, which would be difficult with other drills. The cores from some of the holes were examined. They show plainly the brecciated condition of the ground and the extensive deposition of pink spar. The ore, as might naturally be expected, varies from place to place in the breccia, and the value of the drill is in determining where it occurs in workable quantities. 
Christie.-In the south part of sec. 19, T. 17 N., R. 16 W., on Water Creek, considerable prospecting has been done in a bed of brecciated dolomite. The ore is principally zinc blende associated with pink spar. The extent of the deposit has not been determined, work being in progress at the time it was visited. The opening is in the upper part of the Yellville limestones, and the ore-bearing bed is not unlike the ordinary brecciated deposits of the district.

\section{BAXTER COUNTY.}

The mines and prospects near Mountain Home, Baxter County, are all situated in the Yellville dolomites. In this part of the field the Boone formation has been wholly removed, and the upper portion of the dolomite series is likewise largely worn away by erosion. Prospecting in the southern part of the county adjacent to the area in which the Boone formation is present has not been extensively carried on. It may be that this part will also prove to be within the mining district.

Hawkeye No. 1.-This prospect is situated between East Pigeon Creek and Baird Creek, in the NE. $\frac{1}{4}$ sec. 1, T.21 N., R. 13 W. Two open cuts have been made in the hillside. The rocks which are exposed are more or less siliceous horizontal dolomites. They have been fractured and jointed, and in places brecciated. The ore at this place has associated with it quartz, lining the cavities and depsited on the surfaces of the rock. About 50 tons of crush rock carrying blende and about 20 tons of fairly rich zinc carbonate ore have been piled up.

Hulsenbeck.-These workings (PI. XXVI, A), which are in the SW. $\frac{1}{4}$ sec. 31, T. 21 N., R. 12 W., expose beds of dolomite which have quartz crystals deposited as a thin scale on the surfaces and in cavities. The ore, which is principally blende, is found mainly on the quartz. Some of it has been oxidized to carbonate. There is also some secondary chert exposed in the workings, and this bears evidence in places of having been leached of its ore. Some carbonate has been shipped from this property.

Gambetta.-This prospect consists of shallow shafts and a short tunnel, which is situated in the SE. $\frac{1}{4}$ sec. 3, T. 20 N., R. 13 W. The ore, associated with quartz and calcite, has the appearance of occupying a solution channel in the dolomite.

Lost mine.-The Lost mine is situated in the SW. sec. 2, T. 20 N., R. 13 W. It has produced principally galena. The workings consist of two open cuts in horizontal dolomites, which contain cherty beds. In the north cut a vertical fissure filled with broken dolomite and calcite is seen. It is apparently produced by a slight fault, which has a direction N. $80^{\circ}$ E. The shaft which is sunk at this mine could not be examined because it was boarded up, but some ore has been found in it, as shown by the rock on the dump. 
U. S. GEOLOGICAL SURVEY

PROFESSIONAL PAPER NO. 24 PL XXVI

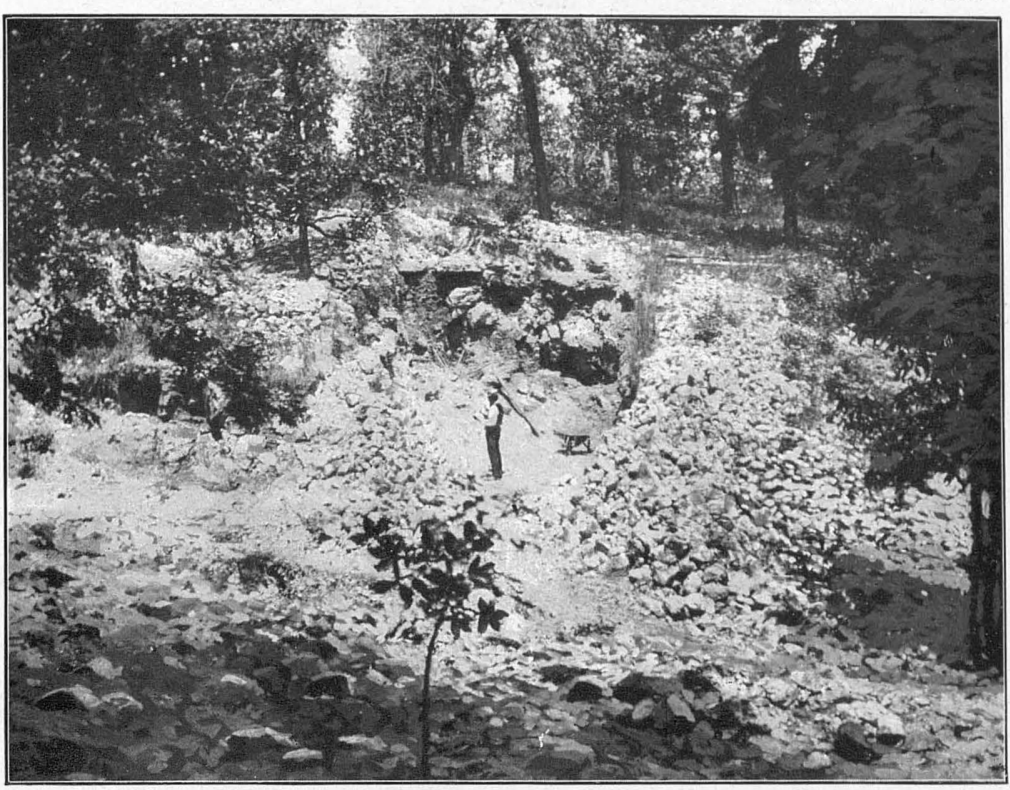

A. OPEN CUT, HULSENBECK PROPERTY,

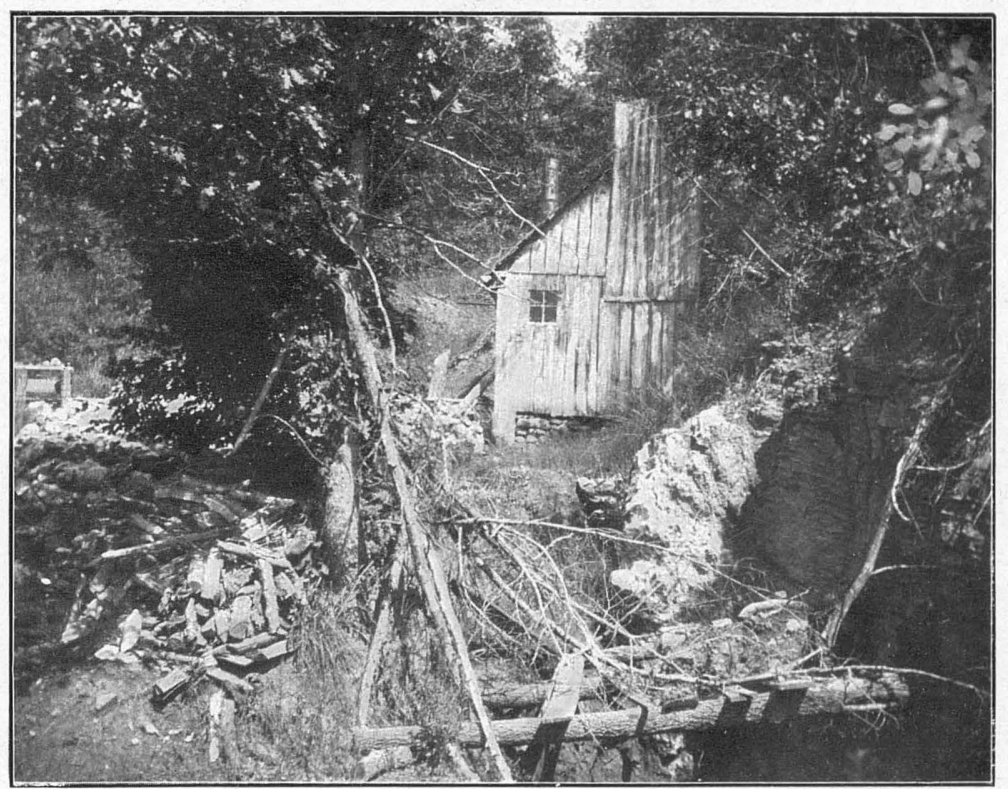

B. FISSURE AND SHAFT HOUSE AT BAKER AND MCGRATH MINE. 

Hopeful.-This prospect is situated in the SW. $\frac{1}{4}$ sec. 25, T. 21 N., R. 14 W. The largest cut exposes a bed of compact dolomite, but slightly fractured, underneath which is a second one of similar character. The bedding plane between them shows undulations. The ore is blende, with a little galena associated with milky calcite. The rocks have not been richly mineralized. No clear structure could be made out which would account for the localization of the deposit.

Bald Dave.-Bald Dave Mountain lies in sec. 11, T. 2 N., R. 14 W. On its northwest slope some blende and galena have been found, as well as zine carbonate, which has resulted from the alteration of the blende. The ore is associated with calcite and some quartz. There are a number of other prospects at this mountain, in some of which there is a brecciated structure.

Gold Standard and Mark Hanna.-The Gold Standard is situated in the SE. $\frac{1}{4}$ of sec. 30, T. 20 N., R. 14 W. The Mark Hanna is in sec. 29, close by. The rocks are even bedded, but exhibit a slight dip to the northeast. The ore consists of zinc blende and carbonate associated with quartz. A considerable amount of hand-picked ore is on the dump at the Gold Standard.

Cedar Gap.-At this prospect, which is in the SW. $\frac{1}{4}$ sec. 31, T. 20 N., R. $14 \mathrm{~W}$., considerable development has been made, disclosing fractured and brecciated beds in open cuts, carrying zinc blende and zinc carbonate in openings of the rocks. The locality seems to be richly mineralized, and a good shipment of ore is awaiting transportation.

Hawkeye No. 2.-This prospect is similar in character to the one just described. It is in the center of sec. 31, T. 20 N., R. 14 W. The surface workings disclose principally zinc carbonate, which has resulted from the alteration of the blende, which is deposited in the fissures and crevices of the dolomites.

Big John.-A number of open cuts which bear this name are situated in the NW. $\frac{1}{4}$ of sec. 5, T. 19 N., R. 14 W. The rocks are dolomites, which contain cavities lined with quartz crystals. A small amount of zinc blende and carbonate is found associated with these druses.

Wallace Knob.-Wallace Knob, near the center of sec. 33, T. 20 N., R. 13 W., is cressed by a low ridge of brecciated material, which has a direction $\mathrm{N}$. $60^{\circ} \mathrm{E}$. The brecciation is evidently due to the dragging of the beds along a fault plane. The prospecting thus far has found a little blende and some pyrite, which has been altered in places to limonite.

\section{SEARCY COUNTY.}

The development in Searcy County is near its northern border, along the valley of Buffalo Fork and its tributaries, especially to the east and west of St. Joe. Considerable prospecting has recently been done, and the building of the railroad will stimulate further work in this county. 
Winchester.-This property is in the SE. $\frac{1}{4}$ sec. 2, T. 16 N., R. 15 W. An open cut has been made in the bed of one of the main tributaries of Rock Creek. The horizon is the upper part of the Yellville formation. The Key sandstone and the St. Joe member of the Boone formation are exposed at intervals along the bluff's of the ravine, sometimes only a few feet above the level of the water and dipping down to the bed of the branch, where the rocks have an undulating structure. The ore of this place is a rich deposit of blende associated with pink spar. The rocks have been fractured and brecciated, and apparently the Winchester claim is about the horizon of a number of prospects which have been more or less developed farther up on this same stream. It is one of the most promising localities southeast of Buffalo Fork.

There are a number of prospects in the valleys tributary to Buffalo Fork from the southeast, but not very much development work has been undertaken. The Yellville formation is exposed in the immediate valleys of the streams, and prospecting has been carried on at horizons varying from a few feet to 200 feet below the Key sandstone. The elevation above the level of Buffalo Fork varies according to the dip of the rocks, and occasionally with definite faulting. At some places ore is found in the bed of Buffalo Fork. At the mouth of a short hollow called Otter Slide a deposit of ore in breccia was seen. Near the mouth of Spring Creek the Noxall prospect exposes a deposit of zinc blende associated with pink spar.

Jackpot (on Buffalo Fork). - High on the bluff on the west bank of Buffalo Fork in the southern part of sec. 8, T. $16 \mathrm{~N}$., R. $15 \mathrm{~W}$., there is an opening under the Key sandstone which is known as the Jackpot. The ore at this place consists of small crystals of blende occurring in a mass of pink spar. The workings indicate that the ore and spar were deposited in a water channel. The distribution of the blende crystals in the spar, and the fact that there is but little zinc ore which is related to the country rock, favors this conclusion. Prospecting with a drill and by means of open cuts is being carried on adjacent to the Jackpot and on the opposite side of the river at lower horizons. There is a fault plainly visible in the bluff a short distance down the stream, but thus far, as is not uncommonly the case in this region, no ore has been found which is immediately in the zone of faulting.

Near the mouth of Water Creek there is an opening in a brecciated bed of dolomite which exposes considerable ore associated with pink spar. This prospect is not named, but is on what is known as the Jones property.

Maumee.-On the west side of sec. 12, T. 16 N., R. 16 W., in the valley of Greenhaw Hollow, is a prospect known as the Maumee. This opening is immediately below the Key sandstone, in horizontal beds of dolomite. The ore is 
associated with pink spar, which appears to be deposited along the water channels and to some extent in jointing planes and bedding planes of the country rock. There are rich masses of blende in the crush rock upon the dump, but an examination of the tunnel indicated that the ore varied considerably in amount from place to place. Here, as at other places where the blende occurs in large masses, the ore is also found replacing the country rock adjacent to the main ore bodies. There is some carbonate and silicate, as a result of alteration of the primary ore. A little chalcopyrite occurs as small crystals on the pink spar. This mineral has been altered by the same oxidizing solutions which have affected the blende and given rise to greenish and bluish copper stains, which oceur sparingly in the secondary zinc ores.

Mud Hollow.-Along Mud Hollow the Ordovician rocks show some folding, and near the mouth of the hollow there is a fault, as shown on the geologic map (Pl. V). The prospecting in this locality is in the west side of sec. 15, T. 16 N., R. 16 W., distant from the fault, at a place where the rocks have been brecciated and fractured but not displaced vertically. The ore is associated with secondary chert and with dolomite spar. It consists of zinc blende, with some carbonate and silicate. Here, as at the Maumee, there is a moderate amount of chalcopyrite, and copper stains are in evidence on the secondary ores, as the result of alteration of this mineral.

Excelsior (formerly the St. Joe).-On Monkey Run, just north of St. Joe, in the south part of sec. 7, T. 16 N., R. 17 W., considerable prospecting has been done near the St. Joe fault, and at the Excelsior a shaft house has been erected. There are some shafts immediately on the fault and others to the north, where the rocks, although considerably fractured, retain a nearly horizontal position. The shafts which are on the fault have found but little ore with the exception of a small amount of carbonate and silicate occurring in the material filling the fault zone. The fault zone is clearly indicated by what is locally known as a "marker." This is a mass of broken rock fragments cemented together, which, upon weathering, remains above the level of the surrounding beds as a rough, bowlder-like mass. In so far as has been made out it was not originally mineralized. Most of the ore thus far found is at a considerable distance from the fault, and consists of zinc blende associated with some pink spar deposited in small fractures, and does not, in so far as now known, occur in large masses. Apparently the expectation of those who began operations at this place was that they would find a rich ore body adjacent to the fault. Further prospecting may develop workable ore at this locality.

Davy Crockett.-In the NE. $\frac{1}{4}$ sec. 9, T. 16 N., R. 17 W., and in the NW. $\frac{1}{4}$ sec. 10, some prospecting has been done to the north of the St. Joe fault. As 4538-No. 24-04-6 
is the case near the Excelsior, no ore has been discovered along the fault zone. What ore has been found is to the north, and is exposed in the open cut. It is zine blende associated with pink spar, and is found in a fractured bed of dolomite.

Big Hurricane.-In sec. 7, T. 16. N., R. 18 W., considerable prospecting has been done on the upper part of Hurricane Branch. An east-west fault extends along the valley at this locality. The downthrow of the fault is on the south side, and brings the Boone flint in contact with the Ordovician. The ore thus far found occurs in the Boone adjacent to the fault, where, apparently as a result of the dragging of the rocks at the time of displacement, brecciation took place. The workings consist of open cuts and a shaft, and drill holes have been sunk near by. The ore consists of zinc blende, with a large amount of carbonate and some silicate; as a result of the alteration of the primary deposit. The rocks in the open cut have a dip to the south, and the ore pitches with the rocks. Development at this place has not been very systematic. There is, however; an encouraging amount of ore in sight. By hand picking carbonate may be largely separated from the sulphide, but from the present workings the output of this mine would be mixed ore.

\section{NEWTON COUNTY.}

The mines and prospects in Newton County occur both in the Boone formation and the Yellville dolomites. The dolomites are found to be ore-bearing in the valleys of Mill Creek, Buffalo Fork, Davis Creek, and Cave Creek, while the developments in the Boone limestone are in the vicinity of Boxley, Jasper, and Cave Creek.

Spier.-About 4 miles west of the Big Hurricane, on the same fault, near the center of sec. 9, T. 16 N., R. 19 W., is the Spier property. The displacement here, as at the Big Hurricane, brings the Boone chert in contact with the Ordovician dolomites, and the crushing of the brittle beds of the Boone has produced a fine breccia, which has been mineralized. A shaft (Pl. XXVII) has been sunk in the ore-bearing rock, and is apparently but a few feet south of the fault. The ore is zinc blende, excepting in the upper part of the breccia, and occurs in small and scattered amounts, uniformly distributed. The Boone has been so finely crushed at this place that the breccia, although consisting of practically the same material as at the Hurricane, bears but little resemblance to the ore-bearing rocks at that place.

In the valley of Shaddock Branch, intermediate between the Hurricane and Spier properties, some prospecting has been done to the north of the fault zone, which has disclosed zinc blende in the Ordovician dolomites. This prospecting is not extensive, but is mentioned here as showing that to the north of the 


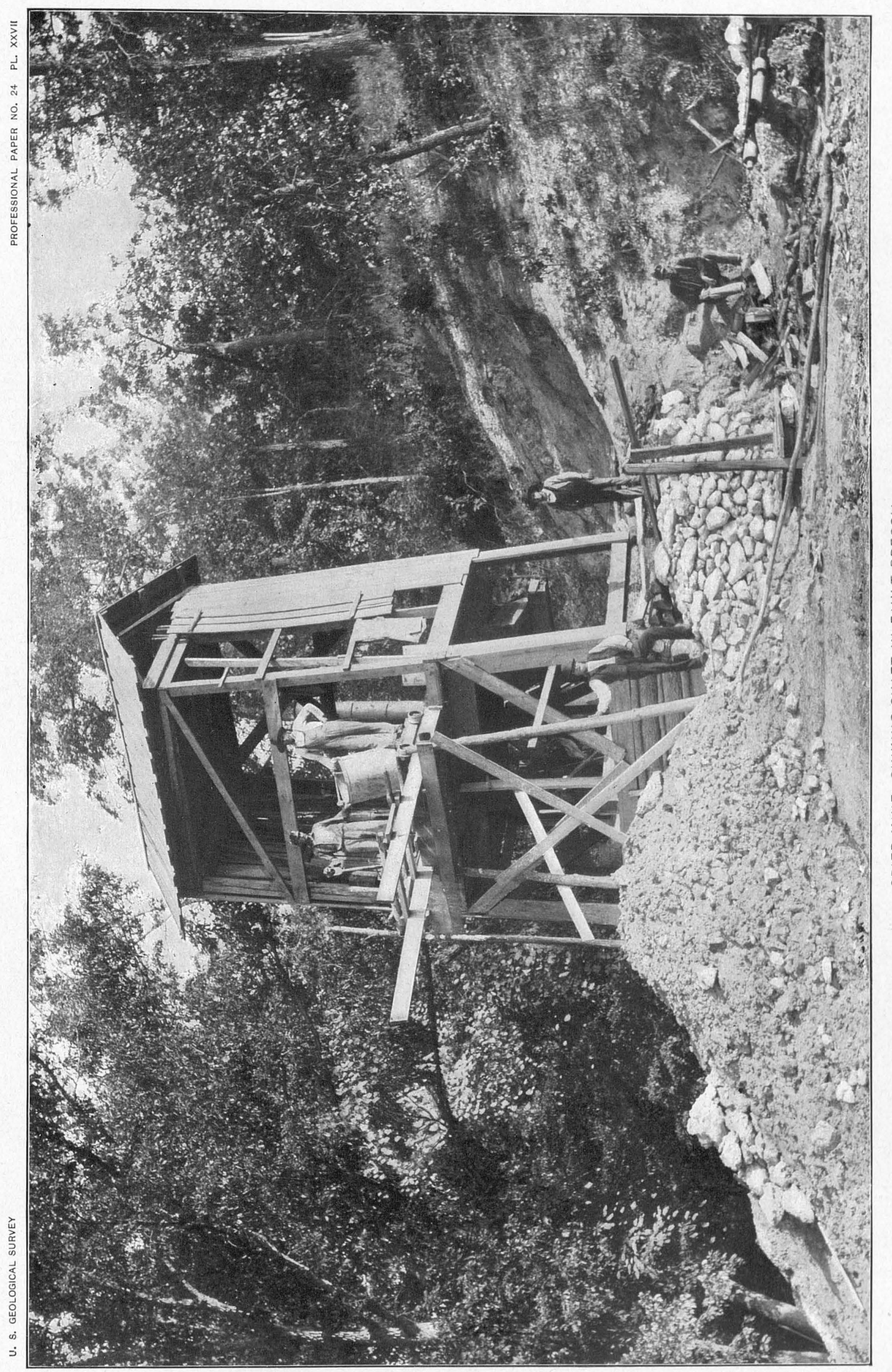



fault, in the Ordovician rocks, where they are relatively undisturbed, ore is found in very much the same horizon and attitude as to the north of the fault at Monkey Run.

Marble City.-In the SW. $\frac{1}{4}$ sec. 29, T. 17 N., R. 20 W., a short distance below the post-office of Willcockson, there is a prospect in the bed of Mill Creek. The rocks at this place are the upper portion of the Ordovician dolomites, the saccharoidal sandstone being exposed on the bluff about 50 feet above. The development consists of an open cut, which shows considerable ore occurring in dolomites, with which are associated quartzose sandstone. The sandstone or sandy dolomite at this place apparently is an original portion of the dolomite series, and has not been infiltrated. It consists of material similar to that which composes the saccharoidal sandstone, but the quartz grains are in a matrix of dolomite. The ore-bearing bed is from 6 to 8 feet in thickness, and in working it Mill Creek has been diverted from its channel. There is some chalcopyrite associated with the ore, and the alteration of this has given rise to bluish and greenish stains, as a result of the small amount of copper present. The rocks at ithis place exhibit fracturing and brecciation. There is considerable pink spar present. The sulphides have been partially altered to carbonates and silicates.

There are a number of openings lower on Mill Creek, which show more or less ore in relations approximately the same as at the Marble City mine.

Canton.-In the SE. $\frac{1}{4}$ sec. 6, T. 16 N., R. 20 W., considerable mining has been carried on, and a small crusher and hand jigs have been operated for concentrating the ore obtained. The deposit at this place, which is in and just below the bed of Mill Creek, has been worked by means of a shaft and open cuts. The rocks show rich zinc blende, occurring in masses associated with pink spar, and there is considerable accessory ore, which has been deposited by replacement of the country rock.

Wichita Belle.-This prospect is situated in the NW. $\frac{1}{4}$ sec. 12, T. 15 N., R. 19 W., near the mouth of a short tributary of Cave Creek. It consists of an open cut in the bed of the stream, and shows zinc blende associated with pink spar in a brecciated bed of Ordovician dolomite. The rocks in this vicinity show some divergent dips, bủt no structure outside of brecciation could be determined at the locality of the prospect. The zinc blende has been altered to some extent to carbonate. Not very much work has been done at this place, but it is probable that the brecciated bed could be more extensively developed.

Old Granby.-In sec. 35, T. 15 N., R. 19 W., near the head of Cave Creek, considerable mining was formerly attempted by the Granby Mining and Smelting Company. The rocks at this place are the upper portion of the Boone chert. The ore, which was obtained by means of shafts, is developed along 
fissures, and is found in material filling the fissures and replacing the country rock. Very little information could be obtained concerning the workings, excepting by examining the material on the dump near the shafts.

Carbonate Nose.-In the northeastern part of the same section in which the Old Granby shafts are located are some workings which show a considerable amount of carbonate. The ore obtained from them was reported, however, to have been principally blende, with some galena.

Goswick.-In the SE. $\frac{1}{4}$ sec. 3, T. 14 N., R. 19 W., there are a number of prospects and shallow pits from which carbonate and blende have been obtained. The surface of the Boone chert at this locality exhibits a number of fissures, and it is on these that the prospects are located. The ore found near the surface is largely carbonate, as a result of surface alteration.

The prospects above described are quite different from those in the northern part of the district. They are in a different formation, and the rocks show a different type of structure. The geology of this region has not been carefully studied, but there is considerable evidence of faulting, which extends in a northeast-southwest direction. The fissures may or may not be related to this faulting. The slickensides observed indicate that the rocks have been under compression, and that movements have taken place in a horizontal plane. The faulting may be of later origin. The concentration of the ore in the upper part of the Boone must be accounted for in a different manner from that which occurs in the Ordovician. Erosion has but recently removed the shales which formerly overlaid the Boone at this place, and sufficient time has not elapsed for the agencies of weathering to have leached out the ore deposits, although this has taken place to some extent. It is probable that the accumulation of ore in the upper horizon of the Boone was the result of the concentration of the original contents of the formation by circulation under hydrostatic pressure.

Panther Creek.-In the NE. $\frac{1}{4}$ sec. 31, T. 16 N., R. 21 W: near the head of Panther Creek, are a number of open cuts, shafts, and tunnels, in the upper part of the Boone formation. The structure at this place indicates that the rocks have been compressed and fractured. The slickensides observed indicate movement both - in the horizontal and vertical planes. The ore found is associated with the fractures, which have a direction of N. $30^{\circ}$ E., and consists principally of zinc blende; but there is some carbonate, and a minor amount of silicate where surface waters have altered the ore. The ore runs in irregular sheets and masses, varying in richness from place to place, apparently with the width of the fissures, it also occurs along the bedding planes laterally from them. Some galena is found associated with the zinc. This is one of the well-defined examples of the association of ore with fissures, which seems to be the common case in the portion of the district where the deposits are in the Boone. 
There are a number of smaller openings and prospects in the vicinity of Panther Creek, but not very much development work has been done on them.

Chimney Rock.-In sec. 7, T. 16 N., R. 22 W., near the head of a tributary of Clifty Creek, there are some openings known as the Chimney Rock mine. They are related to a fault, which may be seen traversing the Boone chert at this place. The walls are slickensided and give evidence of the movement of the rocks past each other. The amount of throw, however, could not be measured. Ore occurs in the broken chert and limestone filling the fissure. This material is exposed at the surface along the line of the fault, standing up as irregular bowlder-like masses. The ore from this mine was principally galena.

Baker \& McGrath.-In the SW. $\frac{1}{4}$ sec. 18, T. 16 N., R. 22 W., on the east side of Villines Creek, there is a mine which is located upon a fissure. The workings consist of an open cut and a shaft (Pl. XXVI, $B$ ) located on the fissure, which has a north-south direction. A considerable quantity of crush rock is piled up near the mine. The ore is principally blende, although galena also is found. It occurs in the material filling the fissure, and the country rock for a short distance adjacent contains accessory ore deposited by replacement.

Bonanza. - This property is similar to the one above described in the character of its ore and the structure of the rocks.

Ponca City.-This prospect is situated in the SW. $\frac{1}{4}$ sec. 24, T. 16 N., R. $23 \mathrm{~W}$. Prospecting was done here some years ago, and at the time the place was visited work was in progress on an open cut, from which considerable ore was being obtained. The ore originally consisted of blende, with some galena, but has been largely altered to silicate and carbonate. Occasionally the carbonate is stained with cadmium, giving rise to the variety known as "turkey fat." An examination of an old shaft and tunnel at this place shows that the ore body is apparently related to fracturing or faulting, which has a direction of N. $20^{\circ} \mathrm{E}$.

Bennett.-In the SW. $\frac{1}{4}$ sec. 26, T. 15 N., R. 23 W., are a number of shafts and open pits from which ore has been obtained. At the time they were visited no work was being done. The material lying on the surface indicated that the ore was largely carbonate. The deposit is apparently related to jointing and fracturing, which has a direction of N. $45^{\circ}$ E. Some ore has been shipped from this mine.

\section{SUGGESTIONS FOR PROSPECTING AND MINING.}

While the study of the district allows certain inferences to be drawn which may be of value in prospecting and in working the ore bodies already located, each individual case requires judgment and experience, since there are so many factors involved. Naturally there is no better rule than the common one of the miners, which is to follow the ore. In doing so the structure of the rocks at a 
given locality should be studied and the general character of the deposits should be determined. The classes of deposits outlined in this paper, while they are intended to explain the genesis of the ore, may be applied by the practical miner to the deposit which he is working.

Thus far the principal difficulty encountered in the district has arisen from the mixed nature of the ore found in surface workings. The oxidized ores are associated with the sulphides and can not be readily separated, so that the concentrates are mixed. Men experienced in handling such ores, however, meet with a fair degree of success by remodeling the mills and reworking the ore. As the production increases, it is probable that smelters will be erected which will handle mixed ore, since this has been done in other fields. At the present time the ores are for the most part purchased by firms engaged in the manufacture of zinc oxide. As the mines are carried deeper, or under sufficient cover, oxidized ores give way to the sulphides, and clean concentrates are readily obtained.

Certain of the deposits produce almost wholly sulphide ore. In them the only difficulty ordinarily experienced is that of finding large and continuous bodies.

The variation in the richness of the bedded breccias has already been alluded to. Sometimes there is an abundance of pink spar, but no ore. Persistent prospecting at these localities usually results in finding more ore, although some of the workings have been abandoned because they are too lean to work profitably.

At the present time there are a number of large mills in the district and relatively few hand jigs. It is a well-accepted fact that ore can be profitably concentrated with hand jigs, and where there is any uncertainty as to the extent of the deposits it would be well to work them with an inexpensive equipment until there is a sufficient amount of ore in sight to justify the erection of a mill. There are certain mills already built which are situated so that they could profitably be run as custom mills, and where experience has shown that the deposits which are intended to supply them are not sufficiently rich to demand their full capacity they could be profitably employed in doing custom work.

A favorable point in the Arkansas district is the absence of water in most of the mines. This is due to the fact that many of them are located on slopes and hillsides, so that the workings are drained. On the contrary, however, it is occasionally difficult to find or store a sufficient amount of water for the milling operations. This difficulty can usually be overcome by choosing a location for the mills a short distance from the mine. In some instances it will be necessary to pump water to the mills. 


\section{OPINIONS OF PREVIOUS WRITERS, $a$}

In the previous reports on the northern Arkansas field certain ideas have been advanced which are not accepted by the writer. These pertain largely to theoretical considerations, and some of them deal with geologic facts. Professor Branner, in describing the breccias, states that the bedded breccias were not formed on fractures, but along ancient underground watercourses. It is apparently his belief that the dissolving of the dolomites caused the rocks to collapse along the water channels, and thus form the mass of irregular fragments which constitute the breccias. An' examination of the pieces which constitute the breccias shows that they are angular, and have suffered relatively little solution. The writer has argued that these breccias were produced by the differential movement of the strata which caused the fracturing of the rocks and the shearing of the pieces past one another, so that they were more or less rotated from their original positions. The breccias when once formed were sufficiently open to afford channels for the circulation of the ground water, and it was due to this fact that the cementing material was introduced. The matrix of the breccias consists largely of pink spar, with which was deposited more or less ore.

Professor Purdue, who had studied the field previous to the work done for this report, had reached the conclusion that the breccias were due to fractures, and during the progress of the summer's work his opinion was strengthened by his observations. His conclusions, which were reached independently, are recited here in confirmation of those of the writer. However, at certain places in the field, especially in the lower horizons of the Boone formation, there is definite proof of the collapsing of the rocks adjacent to sink holes and solution channels. Some of these localities have been prospected. They are distinct in character from the breccias, and are recognized by the miners in the district as old caves or sinks. They usually contain a large amount of clay, and the relation of the undisturbed rocks adjacent to them is clear proof of their manner of origin.

Mr. Bain, in speaking of the breccia deposits, considered them to have been formed along zones of pressure, and accordingly to have their greatest extent in the vertical rather than the horizontal plane. He also mentions limestone conglomerates as occurring in the district. Careful study of numerous localities failed to show the existence of such conglomerates, and it is the opinion of the writer that the beds observed were probably breccias. The relation of these

$a$ Branner, J. C., Zinc and lead deposits of northern Arkansas: Ann. Rept. Arkansas Geol. Survey for 1892, vol. 5, 1900; also Trans. Am. Inst. Min. Eng., vol. 31, p. 572.

Bain, H. F., Preliminary report on the lead and zinc deposits of the Ozark region, Twenty-second Ann. Rept. U.S. Geol. Survey, pt. 2, 1902, pp. 195-202.

Van Hise, C. R., and Bain, H. Foster, Lead and zinc deposits of the Mississippi Valley, read before the Institution of Mining Engineers at the general meeting at London, May 29, 1902: Excerpt from Trans. Inst. Min. Eng., pp. 34, 35. 
so-called conglomerates to the brecciated beds, and the importance of bedded breccias, does not seem to have been recognized by Mr. Bain.

In regard to the faulting of the region, the writer presents an interpretation which is decidedly opposed to the one given by Professor Branner. In Professor Branner's report, certain of the more important faults are figured and described as thrust faults. Careful study of the relations of the rocks, as well as the hade of the fault planes and fault fissures, shows that the displacements are normal in most cases. Because of the large amount of detrital material on the slopes, the exact relations of the beds along the line of the faults are not always determinable. However, the sagging of the rocks on the downthrow side is readily seen to be the greatest at the point of maximum displacement, while on the upthrow side the strata usually retains relatively the same level throughout the extent of the fault.

There are certain places in the field where thrust faulting was observed. It did not give rise to definite lines of dislocation, but resulted rather in buckling and crushing of the strata. The normal faulting is regarded as having taken place subsequent to the compression which produced the brecciation, and as being due to a readjustment following the stresses, or to later oscillations of level of the formations of the region.

In regard to the theory of ore deposition, there are likewise certain differences of opinion. These differences are largely theoretical, although they pertain in some degree to the economic development of the field. Professor Branner described bedded deposits which he thought were contemporaneous with the rocks in which they occur. The ore bodies which he placed under this class are believed by the writer to be due to secondary alteration and replacement of the rocks. An examination of prospects, which are characterized by secondary chert, shows that in many cases the original bedding of the dolomites has been retained in the structure of the chert.

Mr. Bain has given considerable prominence to what he called disseminated ore in compact limestone and unbroken conglomerate. The writer failed to observe any deposits which could be characterized by this description. It is his opinion that the conglomerates mentioned by Mr. Bain are really of the nature of breccias, as above pointed out. At a number of places where the ore bodies are rich the recrystallized country rock carries more or less ore. Such occurrences have been designated in this report as accessory ore, and it is not improbable that it is this type of deposit which was referred to by Mr. Bain as disseminated ore in compact limestone.

In the discussion of the ore deposits of the Mississippi Valley Mr. Bain and Mr. Van Hise have argued that the probable source of the ores is the Ordovician 
dolomites, which in northeru Arkansas are included in the Yellville formation. While the writer has taken a position which does not preclude this possibility, he has also shown that the circulation of the ground water has been largely a downward movement, and he is inclined to the opinion that it is this circulation, rather than the movement of solutions under hydrostatic pressure which has given rise to the ore bodies. The ore has no doubt been in part concentrated from the Ordovician by the downward movement of solutions, but the formation which apparently has been most extensively leached of its mineral contents is the Boone formation. This is known to be ore-bearing at a number of places in the Arkansas field, and in the Ozark region in general it is a source of ore. Wherever ore deposits are found in the Yellville formation, the Boone has previously been present over it. Its superposition, and the presence in it of lead and zinc ores, together with the fact that it has been wasted under the influence of atmospheric agencies and leached by ground water, would seem to make this opinion altogether a reasonable one.

Ore deposition in the Ozark region, and in the Mississippi Valley in general, although controlled by the same general principles, has occurred under varying conditions; and it seems reasonable to expect that while there are in the various districts many similarities, there should likewise be important differences; and, accordingly, no general theory can be offered for the entire area. Thus far the northern Arkansas district appears to warrant consideration as a distinct field, as it is not a counterpart of any district which has been described. 


\title{
DETERMINATION AND CORRELATION OF FORMATIONS.
}

\author{
By E. O. UlRich.
}

Several weeks of the summer of 1902 were spent in collecting stratigraphic and faunal data relating to the geologic formations of northern Arkansas, and of the Yellville quadrangle especially. Most of the field work was carried on in company with Mr. George I. Adams, who was in charge of the survey of the quadrangle. After working out the section in that area, Marshall, Eureka Springs, Fayetteville, and several localities in the vicinity of Batesville were visited. All of these are type localities of formations named and described in the reports of the Arkansas geological survey.

In every case the lithologic and stratigraphic characteristics of the formations were carefully studied, and in most cases large collections of fossils were secured. Since returning from the field these fossils have been sorted and determined in some cases very thoroughly, so that the writer feels reasonably confident of the correctness of the correlations based chiefly upon them. In formulating conclusions, however, all available evidence was duly considered, nearly as much reliance being given to lithologic peculiarities and stratigraphic relations as to faunal aspects.

Beginning with the lowest, the following lithologic formations are distinguished: Yellville limestone, Key sandstone, Izard limestone, Polk Bayou limestone, St. Clair formation, Sylamore formation, Noel shale, Boone formation with the St. Joe limestone member at base, Moorefield shale, Batesville sandstone, Fayetteville formation, Wedington sandstone, Pitkin limestone, Morrow formation, and Winslow sandstone. The relations of these formations to one another and to stratigraphic divisons proposed by previous authors, and also the respective positions of the formations in the time scale, are shown in the acompanying correlation table. 
Correlation table of the Paleozoic formations in northern Arkansas.

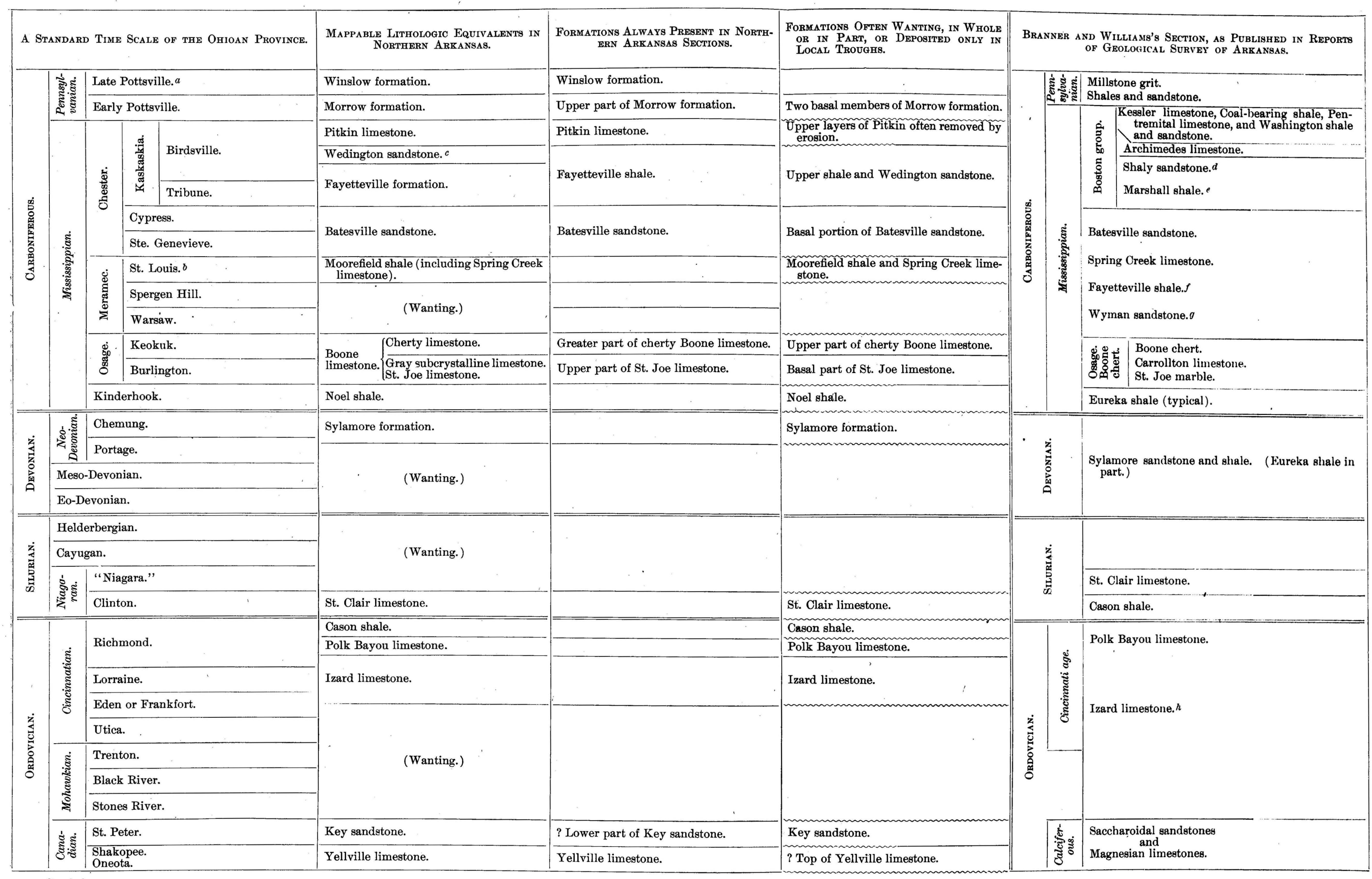
Cambrian.

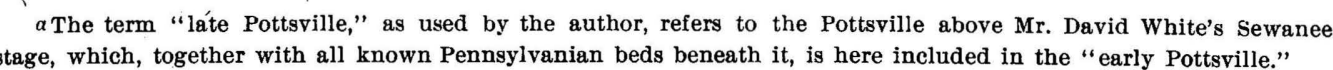
Stage, which, together with all known Pennsylvanian beds beneath it, is here included in the "early Pottssille."
bThe prevaliling opinion as to the St. Louis, Spergen Hill, and Warsaw is that, while they are not strictly conEmporaneous, they are still merely local developments of two or three parts of a single formation, usually called
St. Louis. The writer's work, however, has shown that they are readily distinguishable lithologic units, two of them having a wide geographic distributon, and int three occupying definte and distinct positions in the stratigraphic where all three divisions may be seen, is chosen.
o The reader is referred to the discossion of the Wedington sandstone for Mr. Ulrich's interpretation of the rela.
tions of this sandstone to the Faysetteville shale.

d This seems to be the same as the Wedington sandstone, which Simonds, In his report on Washlington County
calls Batesville sandstone.

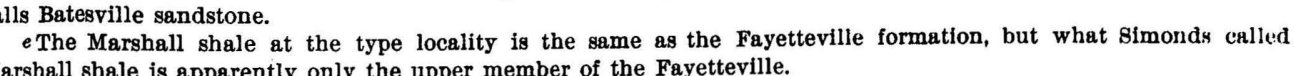
Marshall shale is apparently only the upper member of the Fayetteville.
$f$ The Fayetteville formation really occupies the interval between the Pitkin (Archimedes) limestone above and

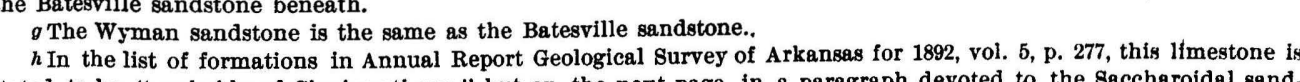
stated to be " "probably of cincinnatia age," but on the next page, in a paragraph devoted to the Baccharoidal sand
stone and Izard limestone, both "are identified as probably lower than the Trenton, or the latter may represent the

4538-No. 24-04. (Face page 90.) 

DESCRIPTION OF CORRELATION TABLE.

The above tabular arrangement and correlation of the lithologic units or formations which it is proposed to recognize in mapping northern Arkansas and southern Missouri (second column) bring out in a graphic manner their relations to all the time divisions so far recognized in the eastern half of the interior continental or "Mississippian province." $a$ The Ordovician portion of the scale is in accordance with the latest revisions of the sections in New York, Ohio, and Tennessee. The Silurian and Devonian follow the New York section, except that the divisions usually recognized beneath the Clinton are omitted. The Mississippian is, according to the section in the Mississippi Valley, worked out and soon to be published by the writer. ${ }^{b}$

The upper Mississippian is given in full, because this portion of the Paleozoic section is best developed in northern Arkansas. It is perhaps unnecessary to add that the author has no intention of intimating that the time terms printed horizontally are even approximately coordinate. That might be claimed only for the names in the Mississippian portion above the Kinderhook. As to the rest, where the Arkansas section is incomplete it was thought sufficient to use terms of higher values only.

The third column shows the formations and parts of formations that, so far as observed, occur throughout the region. In the second and fourth columns are shown the portions of the complete section that, so far as observed, are missing always in Arkansas, and those parts that were laid down only locally in embayments of old shore lines. The fourth column shows also the overlapping formations that were laid down in extending seas and are more and more incomplete basally in the higher parts of the ancient Ozark land mass; it shows also those formations of which the upper portions were in places eroded. The fifth column, finally, shows the classification used in the latest reports of the Arkansas geological survey.

$a$ By this term is meant the area covered by a great though frequently modified inland sea that in Paleozoic time occupied more or less of the territory lying between the Rocky Mountains on the west and the Appalachian Mountains on the east. The name Mississippian was applied to this sea and province by Walcott (Proc. Am. Assn. Adv. Sci., 1894) and adopted by Ulrich and Schuchert in their recent preliminary discussion of "Paleozoic seas and barriers in North America" (Rept. New York State Paleontologist, 1902). The term, however, it confusing, since it has a fixed application to the Lower Carboniferous rocks of America, and therefore its use as a denomination of a sea ought to be restricted to the waters in which the Mississippian series of rocks was deposited. It is also unsatisfactory, since in only a few cases do Paleozoic formations of the eastern half extend west of the Ozark uplift. The only one coming to mind now is the Richmond. All or nearly all of the other formations can be definitely placed either in the eastern or in the western division. It is suggested, therefore, that the Mississippian province be divided into two provinces, the easternmost or Kankakee axis of the Ozark uplift being the line of separation in some cases, the main Ozark axis in others. For the Kankakee axis of the Ozark uplift being the line of separation in some cases, the main Ozark axis in others. For the and Carboniferous by the Appalachian Valley barrier, and during the Silurian in part by the same barrier and in part by the Helderbergian barrier. These two barriers separated it from the Atlantic waters in the Appalachian province. As the western division requires further study before it can be definitely decided that it is not again divisible, into a northern and a southern province, no name is proposed.

$b$ The lead, zinc, and fluorspar deposits of western Kentucky (in preparation). 
Stratigraphic unconformities, when general in the area under discussion, are denoted by a wavy line drawn entirely across the fourth column of the table, either beneath or above the formation name. Horizons of occasional unconformity are distinguished by the wavy line being drawn only half across the column.

Beginning at the bottom of the column the first stratigraphic unconformity shown, except where the Key sandstone has been removed entirely, occurs between the Key sandstone and the Izard limestone, the interval represented by the unconformity at its shortest being equivalent to the Stones River, Black River, Trenton, and Utica ages. As a rule this interval persisted through the remainder of Ordovician time and through all of the succeeding Silurian and Devonian, the first deposits to cover the eroded Key sandstone or, if that is wanting, the Yellville limestone, being either the Noel shale (as at Eureka Springs) or some part of the St. Joe limestone member of the Boone formation of the Carboniferous system.

The six formations intervening between the Key sandstone and the St. Joe limestone member (see table) are all more or less local in their distribution. The Izard limeston and the Sylamore formation are more extensive than the others. The Izard and Sylamore were laid down over a more nearly base-leveled submerged land, while the Polk Bayou, Cason, and St. Clair seem to be restricted to comparatively limited, shallow troughs causing narrow indentations of the old shore lines. As may be expected, therefore, the most convincing evidence of unconformity seen in the field occurs along the borders of the areas containing the Polk Bayou and St. Clair limestones. The St. Clair is even more restricted in extent than the Polk Bayou, and in the borders of the troughs in which both occur the effect of erosive agencies is more obvious than in their central parts, to which, as a rule, the St. Clair limestone is limited.

The upper surface of crystalline limestones, such as the Polk Bayou, always breaks up into bowlders or becomes strongly undulating under ordinary processes of weathering. From observations made in the vicinity of St. Joe, Ark., it is evident that this limestone weathered in Silurian and Devonian times just as it does now, the top of the Polk Bayou, where it is covered by the shales of the Sylamore formation, showing roughly rounded prominences 2 to 3 feet in height. ${ }^{a}$

The other unconformities are not so clearly defined structurally, first, because the erosion did not for various reasons result in so uneven a surface as that of the Polk Bayou and to a less extent of the St. Clair limestone, and, second, the greater or smaller remnant of the Key sandstone, which usually occurs between the Yellville limestone and the Noel shale or St. Joe limestone member (the

$a_{A}$ fine section showing such a contact occurs in the railroad cut one-half mile northwest of St. Joe, Ark. 
intervèning formations being absent) is broken up into a sand and redeposited so as to form a level floor for the succeeding sediments of the Carboniferous, which in these cases come next. This condition is shown very clearly at Eureka Springs beneath the typical exposure of the Noel shale (Eureka shale of Branner). Here the unconformity is beneath the thin bed of material which caps the Ordovician dolomitic limestone, and which has been called "Saccharoidal sandstone." This reworked deposit accordingly does not represent the Key sandstone of other sections, but is a much younger formation-possibly early Mississippian in age.

Where the erosion was not deep and left a considerable portion of the Key sandstone, as originally deposited, the reworking and leveling of the loose sand grains could scarcely have failed to completely obscure all satisfactory evidences of unconformity, so that, even with good exposures, it would be almost futile, to look for them. In these cases paleontology or stratigraphic position only may be used in demonstrating the hiatus.

\section{EVIDENCE UPON WHICH THE CORRELATIONS ARE BASED.}

The fossil contents of a formation can not be discussed satisfactorily without ample illustration. Good figures tell their own story, and therefore furnish independent evidence upon which the experienced paleontologist may rely chiefly in summing up the evidence presented by an author. Without them the reader is obliged to depend solely upon lists of fossils, and the value of these, naturally, is in proportion to the experience and ability of the author in making exact specific discriminations. In making stratigraphic correlations the paleontologist often depends largely upon evidence furnished by undescribed species and varieties which are found in the beds that he is endeavoring to classify, and which perhaps may be known to him alone to occur also in the well-known or at least betterknown formations with which he correlates the horizons in question. This evidence, which it is difficult under any circumstances to present satisfactorily, may, indeed, be of paramount importance in decıding the question of equivalence. The last consideration is furnished in several instances by the Paleozoic section in northern Arkansas, notably the Yellville, Polk Bayou, Batesville, and Fayetteville formations.

\section{ORDOVICIAN FORMATIONS.}

Yellville limestone.-The fossils found in this formation in northern Arkansas and southern Missouri indicate at least two distinct horizons--a lower one with fossils comparatively rare and poorly preserved, and an upper one, so far not recognized in northern Arkansas, containing better and more abundant specimens and more species. Besides these there seems to be a third horizon, comparable 
with the Fort Cassin bed of the Beekmantown in Vermont, and probably holding an intermediate position between the other two. The lowest horizon occurs beneath the "Second Saccharoidal" sandstone, which is occasionally recognizable in northern Arkansas, 200 or 300 feet beneath the upper, or First Saccharoidal, which Mr. Adams proposes to distinguish as the Key sandstone. Still, there is considerable doubt respecting the exact positions of the lower and supposed middle fossiliferous horizons, and some careful stratigraphic and paleontologic work, involving the Calciferous rocks of the whole country, must be done before it will be possible to suggest a satisfactory and approximately permanent classification of these early Ordovician rocks.

The fossils of the beds under consideration consist chiefly of molluses, with occasionally a few brachiopods and trilobites, and more rarely a sponge or sponge-like coral. Bryozoa are wanting entirely. The specimens, especially in the two lower horizons, are nearly always silicified and generally embedded in chert. Many of the species are new, and some are not yet determined, but the following partial list of species collected from the two lower horizons in Arkansas will probably suffice to establish the age of the formation:

\section{Fossils of Yellville formation.}

Tryblidium ovatum Whitfield. ? Ophileta nerine Billings. ? Ophileta disjuncta Billings. Eccyliopterus triangulus (Whitfield). Straparollus intralobatus Sardeson. Raphistoma minnesotensis (Owen). ? Pleurotomaria? postumia Billings.
Murchisonia putilla Sardeson. Murchisonia argylensis Sardeson. Hormotoma artemesia (Billings). Holopea? obesa Whitfield. Subulites exactus Sardeson. Orthoceras lamarcki Billings.

The apparent absence of the upper or Shakopee fauna ${ }^{a}$ in the Yellville limestone possibly is due to the absence of that horizon in the Magnesian limestone series in northern Arkansas. In that case the Yellville limestone would almost certainly be equivalent to the Oneota limestone of the upper part of the Mississippi Valley, in which most of the fossils of the above list occur. The Key sandstone in that case might be regarded as an increased development of the ,New Richmond sandstone of Wisconsin and Minnesota, which there separates the Oneota from the overlying Shakopee. It is very doubtful, however, if this view of the Yellville limestone can be justified. On the other hand, the fact that the Shakopee fauna occurs in excellent development beneath a sandstone that can not be distinguished from the Key sandstone at a locality in Christian County, Mo., less than 60 miles northwest of Yellville, renders it highly probably that this fauna is included in the Yellville formation and was merely 
overlooked in the rather hurried search for fossils in the vicinity of Yellville. Besides, on account of the abundant waste from the overlying sandstone, outcrops of the horizon are comparatively infrequent. Again, it is a well-known fact that in magnesian limestonès the faunas are very unequally distributed, and generally restricted to thin, intermittent bands, so that they may not only be easily overlooked in any given section, but may be absent locally.

The base of the Yellville limestone has not been determined, but as described by Mr. Adams it includes only beds of Ordovicián age. As the lowest rocks in the Yellville quadrangle are very near, if not beneath, the base of the Ordovician, his definition amounts practically to saying that the Yellville is limited below by the base of that system. The divisional line between the Ordovician and the upper - Cambrian, however, is very indefinite nearly everywhere in America, and it will therefore be no easy matter to fix the basal limit of the formation. In the writer's opinion the formation should extend downward to the first unconformity, or to the first important lithologic change, beneath the strata exposed in the type locality. If the extremely cherty lower fossil horizon near Yellville is, as appears highly probable, the equivalent of the Potosi limestone of the Missouri section, then the base of the formation is likely to correspond with Nason's "Edgewise bed" of the same section, and thus include-like the "Magnesian series" of the upper Mississippi Valley, the Arbuckle limestone of Indian Territory, and the Knox dolomite of the Appalachian region--upper Cambrian as well as lower Ordovician strata. According to this conception, the Yellville limestone embraces the interval represented in Missouri by the formations intervening between the base of the Crysta] City or St. Peter sandstone at the top and the unconformity marked by the limestone conglomerate occurring in the shales and shaly limestones which separate the Potosi limestune from the middle Cambrian limestone at Bonne Terre." It becomes, then, also the exact, though thinner, equivalent of the Arbuckle limestone of Indian Territory and Texas.

Key sandstone.-The only fossil remains observed in this sandstone are of a form of Scolithus. The vertical tubes vary from $1.5 \mathrm{~mm}$. to $2.0 \mathrm{~mm}$. in diameter, are nearly straight, and pass entirely through layers 6 to 8 inches in thickness.

The age of this and equivalent formations could not be established if faunal evidence alone were depended upon, since their fossils are extremely rare and, in consequence of the nature of the sediments, very poorly preserved. The stratigraphic position and unusual lithologic character of the Key sandstone, however, furnish criteria that are believed to be incontrovertible. In the first place the constant position of the sandstone next above magnesian limestones, which, when they are at all fossiliferous, always hold the highly characteristic Shakopee 
fauna, definitely fixes the older limit of its age. In Minnesota, Wisconsin, Iowa, and Illinois, the St. Peter sandstone holds precisely the same position, while in Missouri the same interval is occupied by the "First Saccharoidal" or Crystal City sandstone, and the Cap au Gres sandstone. The last is another and more recent name applied by Keyes ${ }^{a}$ to the same formation in the Hannibal, Mo., and Calhoun County, Ill., uplift which crosses Mississippi River above the mouth of Illinois River. As the term Crystal City sandstone is the first geographic name applied to the formation in Missouri, it is to be understood that when that name occurs in this discussion it refers to all the outcrops in the State that can be correlated with the sandstone at Crystal City.

The equivalence of the St. Peter and Crystal City sandstones is established by not only the rocks beneath them, but also by the age of the oldest rocks above them. The rocks immediately overlying the Crystal City sandstone in Missouri vary considerably, it is true, at different localities, ranging from oldest Stones River to the St. Joe member of the Boone limestone. This variation is due chiefly to nondeposition of the intervening formations, but doubtless also in part to pre-Carboniferous, erosion. Still, where the section is most complete, the Crystal City sandstone is followed, apparently quite conformably, by the "First Magnesian" or Joachim limestone, as it is called by Winslow, and this, unconformably, as the writer was recently enabled to establish in Ste. Genevieve County, Mo., by rocks equivalent to the Ridley limestone of the Stones River group in Tennessee. In the upper Mississippi Valley, as a rule, the section above the St. Peter sandstone appear's not to begin with a well-defined horizon that may be correlated with the First Magnesian in Missouri, but in most cases observed by the writer the St. Peter was súcceeded unconformably by strata of Stones River age.

In other places, however, especially near Mississippi River, from a few inches to perhaps 4 or 5 feet of greenish shale or clay intervened between the top of the St. Peter and the base of the Stones River. This greenish shale bed is the only stratum in the upper Mississippi sections that can be correlated with the Joachim limestone of the Missouri section. The suggested correlation is rendered at least probable by the fact that (1) the Joachim limestone, occasionally at least, contains considerable clayey matter, and (2) nothing of essential importance antagonizing the view is known.

Recapitulating the stratigraphic evidence, it is seen that the Shakopee occurs next beneath both the St. Peter sandstone and the Crystal City sandstone. Next above the Crystal City sandstone is the Joachim limestone, followed unconformably by early middle Stones River limestone; and above the St. Peter are 
Stones River rocks, either resting directly upon the sandstone or separated from it by a thin clayey bed that may very well be the equivalent of the Joachim. So far, then, as stratigraphic position is concerned, it will be seen that the limit of uncertainty respecting the exact equivalence of the two sandstones is extremely narrow.

. Lithologically, there is absolutely no constant difference between the St. Peter and Crystal City sandstones. Both consist almost entirely of loosely cemented rounded grains of translucent quartz, and practically every feature of the one may be duplicated in the other. Except where it can be shown to have been reworked or otherwise changed by subaerial agencies prior to its resubmergence in subsequent Paleozoic times, the Key sandstone is in all essential respects lithologically identical with the Crystal City and St. Peter sandstones. Admitting the inclusion of the Shakopee horizon in the Yellville limestone the only reason that may be urged against a positive correlation of the three sandstones is the absence in northern Arkansas of the First Magnesian or Joachim limestone and Stones River rocks which overlie and limit the Crystal City sandstone in Missouri and the St. Peter sandstone farther north. Because of the nature of the deposits, it is extremely unlikely that fossils can ever be found to establish the identity of the Key sandstone and the two other sandstones with which every available line of evidence unites it. Neither is it likely that their identity can be established by tracing the formation, either above or under ground, from exposures of Crystal City sandstone to those of the Key sandstone, since both sandstones have been removed by pre-Carboniferous erosion over a large part of the area intervening between their typical exposures. On the other hand, however, it is even more difficult to prove that the Key sandstone is not strictly an extension of the Crystal City and St. Peter sandstones. Indeed, not a single argument presents itself that is not negatived by facts mentioned in support of the writer's contention that the three sandstones all represent one and the same geologic formation.

Izard limestone.-No fossils that could be specifically identified were obtained from this limestone in Arkansas, but in its lithologic characters and stratigraphic position it corresponds so well with the upper part of the Viola limestone of the Arbuckle and Wichita Mountains of Indian Territory and Oklahoma, that paleontologic evidence is scarcely necessary to fix its horizon in stratigraphic classification. What is regarded as the equivalent of the Izard in the Viola limestone is also extremely unfossiliferous in the Arbuckle Mountains. But it is there, the same as in northern Arkansas, followed by that member of the Richmond group to which Branner has applied the name Polk Bayou limestone. The lower and middle parts of the Viola limestone, on the other hand, afford a number of 4538-No. 24-04-7 
species of fossils indicating an age extending from early Trenton to and perhaps through Utica and possibly Eden ( $?=$ Frankfort).

Polk Bayou limestone.-With a list of fossils like the following there can be no doubt concerning the exact age of this limestone:

\section{Fossils of Polk Bayou limestone.}

Leioclema wilmingtonense Ulrich. Monotrypella quadrata Rominger. Dalmanella jugosa James. Dalmanella macrior Sardeson. Platystrophia acutilirata Conrad. Plectorthis kankakensis McChesney.

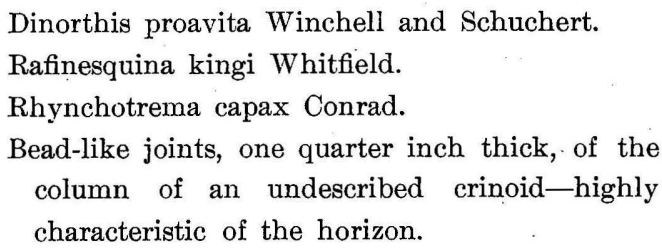

All of the above fossils are characteristic of the Richmond and most of them of that phase of the group that is developed chiefly west of the eighty-seventh meridian. The Fernvale formation of Middle Tennessee ${ }^{a}$ represents practically the same horizon.

The Polk Bayou limestone and the following Silurian and Devonian formations occur only at irregular intervals around the southern border of the Ozark uplift. This irregular distribution evidently is due almost entirely to the fact that the portions now exposed were laid down in generally narrow troughs or embayments of the Ozark shore line. Beginning with the Polk Bayou sea, these bays were successively occupied by the St. Clair and Sylamore seas, but as a rule it appears that the axes of the troughs gradually moved westward, causing the western edges of the embayment formations to advance and the eastern edges to retreat geographically. The deposition of these formations in embayments of a shore line is indicated, the same as those recently described and mapped in middle Tennessee by Hayes and Ulrich, ${ }^{a}$. by the fact that the highest strata, where erosion has not removed them, reach farthest. Occasionally, also, especially in the case of the Sylamore formation, the deposits are sometimes conglomeratic and generally coarser along their borders than in their more central parts.

\section{SILURIAN FORMATIONS.}

St. Clair limestone.-Prof. H. S. Williams has published long lists of fossils from this formation. ${ }^{b}$ Many of the species eited by him do not occur in the material secured by the writer, and these absent species are more especially those that are to be considered indicative of the Niagara age. This may be explained by assuming that there is a higher Silurian horizon near Batesville than those

a Description of Columbia quadrangle: Geologic Atlas U. S., folio 95, U. S. Geol. Survey, 1903. b Ann. Rept. Arkansas Geol. Survey for 1892, vol. 5, 1900, pp. 286-289. 
examined by Mr. Adams and the writer. Our collections contain many of the species named in his lists, besides a few that are not mentioned by him. The latter may have been listed under names that the writer can not accept for them. The fauna as known contains a number of species common to the Clinton and Niagara, and none, or only a few, that according to our present information are restricted to the Niagara. Aside from these possible exceptions nost of the described species are known to occur in the Clinton of Ohio and in the rocks of Indiana, Kentucky, Tennessee, and Georgia that have been correlated with the Ohio Clinton by Foerste. The same horizon occurs also at the base of the Hunton formation in the Arbuckle Mountains of Indian Territory.

As was first pointed out by Williams, ${ }^{a}$ and later by Van Ingen, ${ }^{b}$ the fauna contains two unusual and interesting features. First, the number of European Silurian species contained in it that had not been before recognized in America; and, second, the diminutive size of many of the species, only a few reaching the usual dimensions of the same species in other areas.

The following list comprises most of the characteristic species:

\section{Fossils of St. Clair limestone.}

Streptelasma calyculus Hall.

Phænopora multifida (Van Cleve) Hall.

Dalmanella elegantula Dalman.

Dinorthis fausta (Foerste).

Triplecia ortoni Meek.

Mimulus, sp. near waldronensis (Miller).

Plectambonites transversalis (Wahl.).

Strophonella? patenta (Hall).

Leptæna rhomboidalis (small variety).

Spirifer radiatus Sowerby.

Platyostoma niagarense Hall.

Conocardium (three new species).
Acidaspis obsoleta Van Ingen.

Proetus corrugatus Van Ingen.

Calymene vogdesi Foerste.

Dalmanites arkansanus Van Ingen (near worthneri Foerste).

Sphærexochus romingeri? Hall.

Sphærexochus pisum Foerste.

Ceraurus, near niagarensis Hall.

Illænus; 2 new species near madisonensis Whitfield.

Lichas nereus Hall.

Arges arkansanus Van Ingen.

Arges phlyctenoides (Green) Van Ingen.

The St. Clair limestone has been observed only in association with the Polk Bayou limestone, from which it is sometimes separated by a variable but never heavy bed of shale, to which Prof. H. S. Williams has applied the name Cason shale. Along the shores of the Ozark island both the Cason and the St. Clair seem to be confined entirely to the troughs formerly occupied by the late Richmond sea, and are even more restricted in lateral extent than the Polk Bayou limestone that resulted from the former occupation. The writer has seen no evidence of erosion at the top of the St. Clair limestone (as restricted), but some effects of that kind might be expected, as a result of the elevation of the area,

$\alpha$ Am. Jour. Sci., 3d ser, vol, 48, 1894, pp. 325-331, and Ann. Rept. Arkansas Geol. Survey for 1892, vol. 5, 1900, p. 288 $b$ Siluric fauna near Batesville, Arkansas: School of Mines Quarterly, vol. 22, 1901, p. 327, and vol. 23, 1901 , p. 34. 
which lasted through the remainder of Silurian and the greater part of Devonian time. Erosion effects on the underlying Polk Bayou were observed only along the edges of the bays where the Devonian Sylamore formation rests on it. Coupling this fact with the other-that the geographic distribution of the St. Clair formation is even more restricted than the Polk Bayou-it may be justly argued that the later formation occurred only in the bottoms of the troughs, which position naturally would protect it against erosion agencies. On the other hand, and in accord with observed facts, erosion would have had free play on the elevated borders of the troughs.

Concerning the underlying Cason shale, its position leads one to suspect that it is equivalent to the Sylvan shale of the section in the Arbuckle Mountains, in Indian Territory, and to a similar thin and local shale that overlies the Polk Bayou-Richmond horizon in sections along Mississippi River between Kimmswick and Sulphur Springs, Mo. Again, it is possible that all three of these shales are to be correlated with part or all of the Thebes sandstone and shales, which occupy the interval between the Richmond horizon and fauna mentioned and the Girardeau limestone, in the vicinity of Cape Girardeau, Mo., and Thebes, Ill.

Under proper conditions the Cason shale may prove to be phosphatic. An outcrop of this shale near Duff contained numerous dark pebbles that certainly looked very much like others that were tested and found to be highly phosphatic. As is now well known, most of the late Ordovician, as well as the Devonian formations, on the western shore of the Nashville island contain local deposits more or less rich in calcium phosphate. As the conditions about the western and southern shores of the Ozark island during at least a part of the time were not unlike those that prevailed in Tennessee, similar, though perhaps less extensive and poorer, deposits of this mineral may be expected in Arkansas.

\section{DEVONIAN FORMATIONS.}

Sylamore formation.-Aside from a small Lingula that may be the same as L. spatulata of the Genesee shale of New York, and some conodonts, this formation has afforded no invertebrate fossils. Both the Lingula and the conodonts, however, may be classed anong the characteristic upper Devonian fossils, while it is certain that the same forms are found in the Chattanooga shale of Middle Tennessee. The only other fossil seen from this horizon in Arkansas is an imperfect fish bone, about 5 inches long, 2 inches wide, and possibly one-half inch thick, that may be one of the mandibles of a species of Dinichthys. The specimen is embedded in sandstone. Bones of apparently the same fish occur in the Swan Creek phosphate bed of the Chattanooga shale in Tennessee.

This formation consists of phosphatic sandstone and conglomerate, and dark, 
often fissile, shale. The sandstone is composed chiefly of rounded grains of quartz, evidently derived from neighboring areas exposing the Key sandstone, and more or less phosphatic matter. The latter is often confined to black, clayey, nodule-like pebbles. On the whole the Sylamore formation impresses one as composed of the waste of a near-by shore, and thus agrees, not only in its faunal and physical characters, but also in its origin, with the Chattanooga formation as developed in middle Tennessee. In the latter area the Chattanooga formation represents and doubtless is a direct continuation of the overlapping upper part of the Ohio shale of Kentucky and Ohio.

\section{CARBONIFEROUS FORMATIONS.}

LOWER MISSISSIPPIAN FORMATIONS.

Noel shale and Boone limestone.-The fossils collected from these horizons were turned over to Dr. George H. Girty. The early Mississippian age of this interval being pretty well established, lists of fossils from its members are not so essential as from some of the higher Carboniferous horizons. Being familiar with the Bryozoa, the writer was able to identify in the field most of the species of that class. Among them were three species of the remarkable genus Evactinopora, viz, E. grandis Meek and Worthen, E. sexradiata M. and W., and E. quinqueradiata Ulrich. These occurred near the base of the St. Joe limestone member, one-half mile west of St. Joe. The only other known occurrence of these species is in the vicinity of Burlington, Iowa, where they occur in the lower half of the Burlington limestone. Extraordinary forms like those of Evactinopora always are comparatively short lived, hence they may with much confidence be regarded as holding the same horizon in Arkansas and Iowa. Assuming that this is true, then the underlying Noel shale may, on stratigraphic grounds alone, be correlated with the Kinderhook and since the evidence of the few fossils seen from this shale is all in favor of this correlation, there is little or no reason for doubt as to its correctness.

The Noel shale corresponds in position and lithologic character and doubtless is equivalent to the shale sometimes found at the base of the Tullahoma formation of middle Tennessee. ${ }^{a}$ The remaining cherty portion of the Tullahoma is equivalent to the Boone limestone of Missouri and Arkansas and practically to the Fort Payne chert of Alabama, Georgia, and East Tennessee.

The cherty limestone of the Boone, which makes up the upper and greater part of the formation, was determined in the field, on fossil and stratigraphic evidence, to be of Keokuk age. Beneath this portion of the formation and separating it from the typical, often pink, St. Joe limestone member, is, at least

a Description of the Columbia quadrangle: Geologic Atlas U. S., folio 95, U. S. Geol. Survey, 1903. 
locally, a sparsely cherty, subcrystalline white or gray limestone, generally containing Spirifer logani in abundance, that would be more appropriately referred to the St. Joe limestone member than to the overlying member. If this arrangement were adopted the divisions of the Boone formation would correspond essentially, if not exactly, with the Burlington and Keokuk divisions of Williams's Osage group in the Mississippi Valley north of St. Louis. This white or gray limestone probably is included with the beds to which Williams ${ }^{a}$ has applied the name of Carrollton limestone, but as the section at Carrollton, Mo., seems to contain also the lower part of the more highly cherty upper member, the adoption of the name, except with a modified meaning, would not secure the desired discrimination between the Burlington and Keokuk horizons in the Boone limestone.

\section{UPPER MISSISSIPPIAN FORMATIONS.}

On account of imperfect stratigraphic comparisons and erroneous correlations the Arkansas geologists caused considerable confusion in the nomenclature of the formations above the Boone chert. Probably the most noteworthy of the results of the Survey's recent stratigraphic work in northern Arkansas is the correction of current errors and the determination of the true sequence of the Carboniferous formations and their equivalents in the much better known section along Mississippi River.

Moorefield shale (Fayetteville shale, in part, of Branner).-No fossils were found in this formation, but as the exposures examined were not favorable to their preservation, and, moreover, since no determined effort was made to secure organic remains, the formation may not be entirely barren.

A few miles northwest of Batesville there is a local deposit of highly fossiliferous limestone and limy shale which Prof. H. S. Williams has called the Spring Creek limestone. Apparently this calcareous formation rests on the Boone formation and underlies the typical Moorefield shale. If this is its true position it must represent a part of the hiatus that usually occurs between these two formations. As the outcrop of the Spring Creek limestone corresponds geographically with the trough near Batesville containing the Polk. Bayou and St. Clair limestones, it seems likely that this trough was submerged prior to the wider submergence that resulted in the deposition of the Moorefield shale. It is to be regretted that at the only known locality for the Spring Creek limestone its relations to overlying beds are obscured by a small fault. Still, there is little room for doubt that this formation underlies the Moorefield shale, while the increase of argillaceous matter toward the top of the exposure probably indicates that the calcareous beds grade upward into the shale. Though of small conse- 
quence areally, this calcareous formation is too important geologically to be entirely neglected in the classification of the Mississippian rocks of Arkansas. Perhaps it is sufficiently accounted for by ranking it as a member of the Moorefield formation.

The age of the Spring Creek limestone is determined less by its own fossils than by its stratigraphic position and the faunas of the formations above and beneath it. If the overlying Batesville formation is, as the writer believes, early Chester in age (Ste. Genevieve and Cypress) and the upper part of the Boone of Keokuk age, then the Spring Creek limestone member must fall in between the two. Several points might be discussed in the effort to narrow the choice, but it must suffice for the present to state that the most probable date of its deposition is the St. Louis age. In estimating this opinion it is to be remembered that the writer considers the St. Louis as a distinct formation overlying the Spergen Hill formation, and both of them as overlying the Warsaw.

Mr. Stuart Weller, who gathered most of the material from this limestone reported on by Professor Williams, ${ }^{a}$ evidently secured more material and species than the writer, whose collections, however, include all the strange species that give the fauna so peculiar an aspect when compared with more eastern faunas of similar age. Particularly notable among these are three brachiopods, one a Leiorhynchus, probably correctly identified by Williams as L. papyraceous Meek; the second, Rhynchonella eurekensis Walcott, and the third, a Spirifer, more closely related to the European S. bisulcatus Sowerby than to any American species. The first two of these species occur in Nevada in beds variously identified as Devonian or Carboniferous, though now almost certainly to be referred to the latter.

As to the associated species, of which Williams lists about $35,{ }^{b}$ there are none, unless the form identified with Amboccelia planoconvexa (Shumard) may be so considered, seriously opposing an assignment of the bed to the St. Louis age. On the other hand, Eumetria marcyi (Shumard), the Producti of the types of $P$. cestriensis and $P$. cora, and most of the specifically identified Pelecypoda and Gasetropoda clearly prove that the bed is not older than Warsaw. Considering, further, that the overlying Batesville formation is certainly not younger than early Chester, and that it most probably represents the Ste. Genevieve limestone and the Cypress sandstone of that group, the correlation by Williams and Weller of the Spring Creek limestone with the Warsaw, St. Louis, or Spergen Hill formations seems well sustained.

Williams $^{c}$ publishes lists of fossils from three other localities that he refers

a Ann. Rept. Arkansas Geol. Survey for 1892, vol. 5, 1900.

$b$ Ibid., p. 343 .

cIbid., pp. 353 and 354. 
to the horizon of the Spring Creek limestone, namely, Mountain View, Carrollton, and St. Joe. In the writer's opinion these faunas belong to the upper shale of the Fayetteville formation, that is, to the interval lying between the sandstone member or lens of that formation and the "Archimedes" or Pitkin limestone. This horizon is well exposed and more than commonly fossiliferous at Marshall.

At its top the Moorefield shale includes arenaceous layers, and thus passes rather gradually into the Batesville sandstone. There seems to have been no break in deposition between the Moorefield shale and the Batesville sandstone, but instead a change in kind of material deposited. This change may be readily explained as due to the greater area that was being eroded by the extending river systems and by changes in direction, or the inauguration of new currents, during the growth of the sea. Tracing the shale northward from Moorefield near Batesville, where it seems to have reached its greatest development, it gradually thins out on the southern flanks of the Ozark Island, finally allowing the Batesville sandstone to overlap and rest on the Boone chert. In the southern half of the Yellville quadrangle it is probably wanting as a rule, while its maximum thickness here does not exceed 10 feet. At Marshall, where Branner mapped the shale as Fayetteville, and a few miles southeast of St. Joe, the lower part includes a layer of oolitic limestone. That the shale at these localities is not the Fayetteville becomes evident from the facts brought out in the following discussion of the fauna of the Batesville sandstone.

Batesville sandstone (Batesville sandstone of Branner, not Simonds; Wyman sandstome of Simonds). - The fauna of this horizon has been made the subject of a special paper by Mr. Stuart Weller. ${ }^{a}$ In this paper he describes 30 species of fossils collected at the typical exposures of the formation near Batesville. Thirteen of this number are regarded as new. As a result of his study he correlates the Batesville sandstone with the Aux Vases sandstone of Illinois and the Maxville limestone of Ohio.

A special effort was made to secure a good representation of the fauna of this sandstone. Two of Mr. Weller's localities near Batesville were visited, 31 species being secured at one and 26 species at the other. The writer succeeded in obtaining the same number of species as Mr. Weller, but not the same forms, about one-third of the species collected not being in common. Three other exposures were searched with better success, one at Marshall and two in the vicinity of St. Joe. The Marshall locality afforded 39 species. Only one of the St. Joe collections - that from rocks thrown out in digging a well in the villagewas studied, the number of species amounting to 53. The other lot, secured from the basal beds, contained some unusually good material, but was lost in transit.

$a$ Trans. Néw York Acad. Sci., vol. 16, 1897, p. 281, 
Excluding the "fucoids," the total number of distinct species making up the list from these four localities is 98 . Of this number, 41 species occur also in the sandstone lens or member of the overlying Fayetteville shale, and these should be deducted if the comparisons between the typical Batesville and the "Wyman" sandstone of the other localities are to be entirely trustworthy. This leaves 57 species to be considered. In judging of 'the result of the comparison it should be borne in mind that the Batesville collections were derived from the lower part of the sandstone, those from Marshall represent an horizon nearer the middle, while those studied from St. Joe come from the upper 10 feet.

Of 47 species from the two Batesville localities, which will be treated as one, 19 are found beyond the middle of the Fayetteville shale. Deducting these, leaves 28 characteristic Batesville sandstone species. Twelve of these occur also at either Marshall or St. Joe, or at both, with 8 at the former and 7 at the latter locality. Including most of the species of long range, 29 out of 47 Batesville species have been found also in the "Wyman sandstone" at Marshall and St: Joe. Either proportion, $\frac{12}{2} \frac{2}{8}$ or $\frac{29}{4} \frac{9}{7}$, representing species common to Batesville on the one hand and Marshall and St. Joe on the other, is more than sufficient to establish the equivalence of the rocks under consideration. The value of the evidence upon which this conclusion is based is considerably enhanced by the fact already mentioned that the Batesville collections come from the lower part of the sandstone and that the St. Joe locality, whose fossils were studied, represent the top.

According to the collections made by Mr. Adams and the writer, 16 species out of a total of 47 are known only from Batesville, while 19 pass into the Fayetteville formation; 14 species out of a total of 39 are known only from Marshall, while 13 occur also in the Fayetteville; and 16 species out of a total of 53 occur only at St. Joe, while 28 of the number pass upward into the Fayetteville. As might be expected, the proportion of species passing upward into the Fayetteville formation to the total number is greater in the upper part than in the lower.

The upper part of the formation in the vicinity of St. Joe contains a number of interesting fucoids, among them a large Helminthoida and a good species of Scalarituba, a genus recently proposed by Weller. ${ }^{a}$ The same horizon and fossils were observed at Batesville also, holding about the same stratigraphic position.

Weller's correlation of the Batesville sandstone with the Aux Vases sandstone of Illinois and Missouri is very close. He seems, however, not to have been acquainted with the fauna of the Ste. Genevieve limestone that intervenes, in western Kentucky, southeastern Missouri, and southern Illinois, between the

a Weller, Stuart, Kinderhook faunal studies, No. 1: Trans. St. Louis Acad. Sci., vol. 9, 1899, p. 12. 
Cypress sandstone (=Aux Vases sandstone) and the St. Louis limestone. This fauna contains many species suggesting the Chester, but almost equally as many relating it to the St. Louis. It occupies just the position suggested by the mixed St. Louis-Chester fauna of the Batesville sandstone. Indeed, a comparison of the Ste. Genevieve and Batesville faunas reveals a considerable number of species common to both. It is to be regretted that many of these are new to science and, further, that the fauna of the Ste. Genevieve limestone has not yet been published. Under the eircumstances, therefore, it would be of little value to add a list of species to this discussion.

The Batesville sandstone having been considered by the geologists of the Arkansas survey as overlying the Fayetteville shale, it followed very naturally that when they found a sandstone beneath the shale it had to be considered as distinct from the Batesville. Hence, the "Wyman sandstone" became a necessity. The same error concerning the stratigraphic relations of the two formations caused them to propose another name for the shale above the Batesville sandstone at Marshall. Now that it has been shown that the Batesville sandstone really underlies instead of overlies the Fayetteville shale, and that the stratigraphic succession is essentially the same about Fayetteville and Marshall, the two names Wyman sandstone and Marshall shale naturally fall into the synonymy, respectively, of the previously named Batesville sandstone and Fayetteville shale. In consequence of these corrections of nomenclature the shale beneath the Batesville sandstone was left without a name. Being a mappable lithologic unit south of the Yellville quadrangle, Mr. Adams proposes to call it the Moorefield shale.

At the typical locality the Batesville sandstone attains considerably greater thickness than has been observed elsewhere. Here its base is also somewhat shaly, but the shale is decidedly arenaceous until the section descends into the top of the underlying Moorefield shale. The rest of the formation, comprising much the greater part, is composed of nearly pure sandstone. In the more northern exposures, especially those located within the Yellville quadrangle, the fresh sandstone is strongly calcareous, some of the beds being more properly called arenaceous limestones. As it is to be expected from this change in lithologic character the volume of the formation decreases northwardly, the beds becoming at the same time also more diversely fossiliferous with the increase of their calcareous constituent.

Fayetteville shale (Fayetteville shale of Simonds and Branner and Marshall shale of Branner).--Until rezently this formation has been considered as "almost if not completely barren of fossils." As a rule this appears true, but the shale contains calcareous and arenaceous bands and lenses that are simply crowded with organic remains. A large proportion of these also is excellently preserved. 
The lower half of the formation has for several years been known to contain calcareous lenses or concretions holding a considerable number of Cephalopoda and Pelecypoda, while the upper part, exposed in the railroad cut at Fayetteville, has afforded a Batostomella, a few Brachiopoda, and several mollusks.

In the course of the writer's investigations a bed of sandstone, more or less highly calcareous when fresh, was discovered, first in the vicinity of St. Joe and later at Fayetteville. The fossiliferous portion of this bed has a maximum thickness of less than 10 feet. 'The result of the study of the fossils from this bed is a list comprising 42 species from the first locality and no less than 92 from the second. Thirty of the 42 species collected near St. Joe occurred also in the Fayetteville collection. Adding the remaining 12 to the 92 found at Fayetteville we have a total of 104 species.

Many of these species are new to science and the majority of these again are not known out of Arkansas. A large number, however, of both old and new species are recognized as forms marking the lower half of the Kaskaskia limestone division (i. e., the middle part) of the Chester group of shales, sandstones, and limestones in Illinois and Kentucky. The writer, therefore, is satisfied that the Fayetteville formation represents that portion of the Chester age. This opinion is confirmed by the overlying Pitkin limestone, which he is equally confident represents an upper part of the Chester group of the Mississippi Valley. So far as observed by the wr.ter, the fauna of the Pitkin agrees better with that of the upper limestone of the proposed Birdsville formation of the Chester than with any of the other divisions.

In arriving at these conclusions chief reliance is placed upon certain undescribed Pelecypoda and species of Bryozoa, like Archimedes compactus Ulrich, A. communis Ulrich, and A. swallovanus Hall, which occur in the Fayetteville fauna, and in Kentucky and Illinois are restricted to the basal part of the Birdsville and to the underlying Tribune limestone.

The Fayetteville formation consists of an upper and a lower shale member, with a sandstone lens or wedge between them. The middle member, which may represent the Wedington sandstone of this report, appears not to have been observed or recognized before at Fayetteville, the typical locality, but it outcrops there at several points, notably at the north end of the railroad cut, and, better, 100 yards or so farther north in a gully on the west side of the track. At both of these points the bed is very calcareous, but weathers into a rusty porous sandstone, crowded with Chester fossils. It is only about 4 or 5 feet thick here, and possibly disappears entirely or occurs only as occasional lenses farther west. At Pilot Mountain, 2 or 3 miles east of St. Joe, however, it consists of thin, even-bedded fine-grained sandstones at the top, and layers of similar sand- 
stones alternating with arenaceous shales below, the whole aggregating a thickness of 60 feet or more. It is very improbable that the whole of these 60 feet are equivalent to the bed at Fayetteville. More likely the lower half represents an arenaceous phase of the upper part of the lower shale of the more western locality, leaving the upper half, which contains the, same fossils, as the representative of the calcareous sandstone member of the Fayetteville section. The upper shale apparently decreases in volume eastward from Fayetteville, being either wanting or only a few feet thick in the vicinity of St. Joe and Pilot Mountain. At Marshall, however, this member is as thick as at Fayetteville.

Wedington sandstone (Batesville sandstone of Simonds). - The writer had no opportunity to study this formation in the typical locality, and as no fossils were secured there by other members of the Survey, it is impossible to say now whether there is a fauna from this horizon or not. According to the evidence now available, the Wedington sandstone is a wedge, thickening westward and possibly eastward, lying on Fayetteville shale. But whether these underlying shales are of the upper or of the lower bed of the Fayetteville formation-an important point-is not known. ${ }^{a}$. If the upper bed is really not present in any of the sections containing the Wedington sandstone, then this sandstone must be a later formation, probably overlapping northwardly and westwardly during the time there represented by the unconformity between the Fayetteville and Pitkin. This unconformity was definitely recognized in several sections near St. Joe, where the upper bed of the Fayetteville shales is reduced to a thickness of 15 feet or less, even before the much greater thicknesses of the upper bed in the sections at Marshall and Fayetteville had been examined. With an unconformity indicating land conditions to the north of these overlapping formations, it is quite possible that farther south, where the deeper part of the Fayetteville basin occurs, deposition continued through a part or all of the time. This deposit would be the Wedington, and it is according to this interpretation that it has been mapped by Mr. Adams.

On the other hand, if the land conditions so clearly indicated in the sections about St. Joe were more widely extended than is demanded by the view just advanced, then the Wedington sandstone requires a different explanation. A plausible view in that case would be that the Wedington sandstone is an extension and expansion of the fossiliferous sandstone member above described as diriding the Fayetteville formation into three parts, viz, a lower and an upper bed of shales and an intermediate bed of sandstone varying in thickness, so far as observed by the writer, from 3 to 60 feet. 'If the latter view is the

a An intermittent bed of shale, identified as Marshall shale, is shown in columnar sections published by Simonds in his report on Washington County, Ark. As this shale overlies the Wedington sandstone, which he calls Batesville sandstone, the writer regards it as highly probable that it is the partially eroded remnant of the upper member of the Fayetteville. 
correct one, then the Wedington sandstone should be considered as a member of the Fayetteville formation rather than as a distinct formation. Otherwise it would be necessary to give a new name to either the upper or the lower bed of shale; and that would produce undesirable results. Thus, if the name Fayetteville should be retained for the upper member, then it would stand only for the lesser and more unequally distributed part of the shale formation for which the name was proposed originally. On the other hand, if the lower bed should be selected as the more appropriate, the excellent exposure in the railroad cut at Fayetteville could no longer be referred to as an example of Fayetteville shale because it would then belong to the newly defined formation.

Though the writer has no intention of taking a definite stand in the matter, it yet seems desirable to state that he prefers the second of the two perhaps equally plausible interpretations above suggested.

Pitkin limestone.-The fauna of the Pitkin limestone, heretofore denominated Archimedes limestone, is undeniably of Chester age and, indeed, has been so considered by all writers. However, the recognition of the Pottsville or early Pennsylvanian age of the overlying members of the Morrow formation, necessitates some modification of views held heretofore. In consequence of the transfer of the Brentwood or "Pentremital" limestone, one of the members of the Morrow formation, which also had been commonly regarded as of Chester age, from the Mississippian to the Pennsylvanian series, it is obvious that the Pitkin limestone may now take a higher position in the geologic scale than was assigned to it before. As has been stated on a preceding page, the fauna of the Pitkin (Archimedes) limestone fully warrants placing the formation well up toward the close of the Chester. The unconformable contact with the underlying Fayetteville also tends to place this limestone high in the Chester group. Under the circumstances, it seems to the writer that the Pitkin limestone can not be considered older than the upper part of the Birdsville formation, which is the uppermost of the four divisions into which the Chester group is divided in western Kentucky. Indeed, it is believed that the Pitkin includes beds at the top that are of even later date than any Chester strata remaining in the Mississippi Valley sections of that group, since the top of the Chester was there subjected to erosion through a longer period of time than it was in Arkansas.

EARLY PENNSYLVANIAN FORMATIONS.

Morrow formation.-Counting from the base upward, this formation includes the Washington shale and sandstone, the Brentwood (Pentremital) limestone, the Coal-bearing shale, the Kessler limestone, and an unnamed bed of shales and 
sandstones of the geologists of the Arkansas survey. Until recently these beds, excepting the uppermost, were included, together with the underlying Pitkin (Archimedes) limestone and Marshall shale, in the Boston group of Branner, and placed at the top of the Mississippian series. The two latter formations, as the writer has endeavored to show, are certainly not older than the upper or Kaskaskia limestone division of the Chester group, which includes the latest deposits of the Mississippian series in the basins east of the Ozark uplift.

The Morrow formation therefore must represent a later time interval than the Chester as developed in the Mississippi and Ohio valleys. That it is not to be viewed as an upward extension of the Mississippian series is demonstrated (1) by the existence in Arkansas of a well-marked unconformity at the top of the Pitkin, which horizon corresponds with the wide spread unconformity at the top of the Chester in the Ohio Basin, and (2) by the Pennsylvanian aspect of the marine faunas of the Morrow. On seeing the stratigraphic relations of the various members of the formation to each other, and more particularly to the underlying Pitkin, the writer at once came to the conclusion that they are younger deposits than any Mississippian formations known to him. Nor have the fossils from the limestones, seen then and since, caused any modification of the view expressed in the field. The only questions now remaining unanswered are: What are the relations of the Morrow formation to the Pottsville? Are all or only some of its members represented in that great series of shales, sandstones, and conglomerates of the Appalachian and more western portions of the Ohioan province?

As is well known, the Pottsville group embraces many beds beneath the strongly conglomeratic (Millstone grit) upper member that constitutes the most characteristic and, in many areas, the principal or only lithologic unit of the group. All parts of the group, and more particularly the portions beneath the main conglomerate, seem to have leveled the earth by filling the great hollows that had resulted from the emergence at the close of the Chester, and the severe orographic movements and subsequent adjustments that followed close thereafter. Naturally the group affords everywhere the clearest evidence of its overlapping character, the earliest deposits occurring only in the deepest troughs, while those of subsequent dates spread wider and wider over the sloping flanks of the anticlinal ridges and domes.

As a rule, marine faunas are wanting in Pottsville deposits east of the Mississippi, and so far none has been described in that region. This is due probably almost solely to the turbid condition of the water, which rendered it unfavorable to the invasion and development of animal life. Even the few hardy 
species that may have ventured or possibly were driven in, had but a small chance of living in the disturbed waters.

But were there no areas on the continent in which marine faunas continued to exist through at least the earlier parts of the Pottsville epoch? The writer has satisfied himself that there were, and that we have in the limestones of the Morrow formation the remains of periodic invasions of such faunas; and further that these earliest Pennsylvanian faunas existed perhaps without interruption in basins to the southwest of northern Arkansas. But the last phase of the problem can not be discussed here except to barely indicate the source of the evidence upon which the writer's view is based. This is in the Bend limestone and shale of central Texas, which is, as maintained by Cummins, of Pennsylvanian age and not Mississippian. This Texan formation, it is believed, affords perhaps the most complete or rather the least imperfect record of these as yet little known early Pottsville faunas that we are likely to find.

The occurrence of Pentremites in the fauna of the limestones (Brentwood and Kessler) of the Morrow formation ${ }^{a}$ imparts a more ancient aspect to it than, according to present knowledge, looks right in a Pennsylvania fauna. This occurrence, however, seems due to local conditions. Pentremites, as is well known, do not occur in the Far West in rocks correlating with late Mississippian deposits. ${ }^{b}$ In the limestones and shales of the Chester group, however, species of this genus are extremely abundant-indeed, the genus attained the acme of its development, both in species and individuals, at this time and in the areas embraced by the Ohioan province. The stock was still vigorous when the almost general emergence of the Ohioan province at the close of the Chester partly exterminated it and forced its remnants southwestward into the Mississippian embayment. With the resubmergence of the land that inaugurated the Pottsville epoch the survivors of the stock returned where and when they could; and is it not quite reasonable to expect that the favorable conditions prevailing along the southern shore of Ozarkia, as the ancient landmass gathered about the nucleus of the Ozark uplift may be called, would be accepted? Some of the rest of the Morrow fauna, however, probably came in from the Far Northwest, where, according to deter-

$a$ Dr. George H. Girty has brought together and proposes in the near future to describe an excellent collection of fossils from these limestones.

$b$ In a list of fossils published by Meek in 1873 (U. S. Geol. and Geog. Surv. Terr., pp. 468-470) as from "Old Baldy," near Virginia City, Mont., two species of Pentremites are identified, one doubtfully, with well-known Chester species. The list comprises 38 species, determined generically, and of these less than half are identified specifically. Meek regarded the fossils as probably indicating late Mississippian, but an analysis of his list casts considerable doubt upon this determination. It contains no less than 8 names of species that are considered good Pennsylvanian fossils. In the light of the Morrow fauna, may not at least a part of the section at "Old Baldy" prove to be contemporaneous with the Arkansas deposits under discussion? 
minations by Meek (see note on preceding page), ordinary Pennsylvanian fossils seem likewise to occur in association with Pentremites.

The typical section of the Pottsville doubtless contains many beds that, on account of the overlapping character of this group of formations, are not represented in other sections. It is only the upper or main zone of conglomerates that attained a geographic distribution at all comparable to that of the middle part of the Pennsylvanian series. It is this conglomeratic zone that is represented in the lower Ohio and Mississippi valleys by the Mansfield sandstone of the Indiana geologists and in northern Arkansas by the Winslow. We have, then, a datum line upon which we may proceed further in the effort to determine the stratigraphic equivalents of the Morrow formation in the Appalachian section.

Mr. David White, whose determinations of Carboniferous fossil plants are deserving of the highest confidence, refers the middle or "Coal-bearing shales" member to the lower or Sewanee stage of the upper Pottsville. This determination is quite acceptable to the writer, except that he would prefer, because of extensive orographic movements following the Sewanee stage, to call it lower Pottsville. However, that point has no immediate bearing upon the questions here at issue, the important feature of Mr. White's determinations being that it leaves a large series of deposits in the Appalachian section with which the two lower members of the Morrow formation may be correlated.

So far as the writer's limited comparisons of the fauna of the Brentwood limestone, which underlies, and the Kessler limestone, which overlies the Coal-bearing shales, have extended, they have appeared alike in all essential respects. There is, therefore, no known reason for believing that the Pentremital limestone belongs to an earlier or different group of rocks than is indicated by the plants in the intervening Coal-bearing shales. Of course, the Morrow sediments beneath these shales can not compare in thickness with the beds supposed to correspond in the Appalachian section; but that can have no adverse effect upon the correlation, since the relative thickness of clastic formations depends, aside from other obvious circumstances, entirely upon local conditions of the land supplying the material; and under average circumstances limestones must have taken longer to form than sandstones and shales. Besides, there are localities in the Appalachian region, notably the one in which the Greenbrier limestone occurs, in which no unconformity has been observed between limestones and calcareous shales holding a Chester fauna and a following series of rocks that are classed as Pottsville. It would, therefore, appear that in such limited areas or troughs sedimentation may have continued without interruption from late Mississippian into early, yet undeniable, Pennsylvanian time. If this possibility proves to be a fact, then the 
Morrow formation, as known to-day, contains no strata quite so old as the earliest Pennsylvanian deposits in certain Appalachian regions. Accordingly, providing the Pottsville group extends to the base of the Pennsylvanian, the Morrow formation must be referred to that group. In the correlation table on a preceding page the formation has been so arranged, and the only point connected -with the writer's estimate of the Pottsville, as given in the table, that may not be acceptable to Mr. White and other geologists, is the implied restriction of the upper (late) Pottsville to the widely distributed conglomeratic zone and the inclusion of the remaining beds in the lower (early) Pottsville.

4538-No. 24-04-8 



\section{IN DEX.}

Adams, George I., field work by

Almy mine, description of

view of, plate showing.

view of, plate showing.

Arbuckle limestone, equivalent of .

Archimedes limestone, a name for the Palken lime-

$$
\text { stone. }
$$

correlation of.

Arkansas, northern, lithologic formations distinguished in.

lithologic formations in, correlation of, table show-

$$
\text { ing. }
$$

physiography of .

zinc and lead deposits of, historical sketch of

zinc and lead district of, faults in

generalized section through .................. 32

geologic formations in

limits of.

map of, showing general geology and principal mines and prospects

ines and prospects in .....

mes and minerals in

phyicel changes in, history of

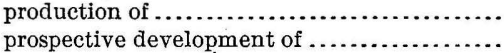

structure of, origin of...

transportation facilities in.

$104,105,106$

Bain, H. Foster, cited on origin of the breccia deposits. 87, 88

Bain, H. Foster, and Van Hise, C. R., cited on origin of ore deposits of the Mississippi Valley...... 88-89

Baird Creek, prospects on..................

Ber \& McGrath mine, description of .

view of, plate showing

Bald Dave mine, description of

Bald Jesse mine, description of.

Batesville, Moorefield shale near

Polk Bayou formation near.

Silurian limestones near.

Batesville limestone, age and stratigraphic place of..

Batesville sandstone, character, occurrence, and thickness of ...........................26-27

correlation of .

stratigraphic place of.......................... 108-109

Batie mine, description of...................... 69-70

Baxter County, mines and prospects in, description of. 78-79

Bear Creek, developments near.

Bear Hill mine, description of ........................

view of, plate showing

Bedded breccias, sulphide deposits in ................

Ben Harrison mine, description of .....................

Bend limestone, age of

Bennett mine, description of ge.

Page.

view of, plate showing $\ldots \ldots \ldots \ldots \ldots \ldots \ldots \ldots \ldots \ldots \ldots \ldots+70,73$

ig Buffalo mine, description of...................... 70

Elephant mine, description of .................. 70

g Hurricane prospects, description of ............. 812

$\begin{array}{rr}\text { Big John mine, description of ........................ } & 79 \\ \text { Birdsville formation, correlation of ............... } & 109\end{array}$

Blende. See Zinc sulphide.

Boat Creek mine, description of .................. 76-77

oat Mountain, coal prospects at.................... 28

Boone County, mines and prospects in, deseription of. $63-66$ oone formation, character, occurrence and thickness
of ........................................

fracturing and fissuring in..................... 33

ore deposits in .............................. 29

ne limestone, character and fossils of........... 101-102

correlation of.................................. correlation of $\ldots \ldots \ldots \ldots \ldots \ldots \ldots \ldots \ldots$
stratigraphic place of.$\ldots \ldots \ldots \ldots \ldots \ldots \ldots \ldots \ldots \ldots \ldots$

ing.................................. 34

Breccias. See Fault breccias; bedded breccias.

Brecciation, production of, by stress, diagram illustrat-
ing.....................................

Brentwood limestone, equivalent of ....................

stratigraphic place of......................... 109

Buffalo Fork of White River, mines and prospects on ............................ $75-76,79,80$

Burchard, Ernest F., aid by ...................... 13 Burlington escarpment, elevation of ................ 17 Calamine, Ark., zinc smelter erected at............ 14

Calamine, occurrence and character of ............. 39

Calcite, occurrence and character of ................. 41

Canton mine, description of ....................... 83

Carbonate Nose prospect, description of ................ 84 Carboniferous formations, character and fossils of .. 101-113 correlation of, table showing.................. 90 Carboniferous s s stem, formations of .............. 24-29 Carrollton limestone, correlation of ................... 90, 102 Cason shale, correlation of ....................... 90 stratigraphic place of ...................... 99, 100 Cave Creek, prospects on ......................... 83 Cedar Gap mine, description of .................... 
Cementation, relations of to rock weathering Cerussite, occurrence and character of Chalcopyrite, occurrence and character of Chert, secondary, association of sulphide deposits with

occurrence and character of Chimney Rock mine, descrip ${ }^{\star}$ ion of.................. Christie mine, description of Clabber Creek, mines and prospects on .............. $72-73$ Clear Creek, Yellville formation on................ 19-20

Clifty Creek, mines on

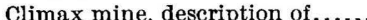
fault near view of, plate showing

Coal-bearing shale, correlation of 67 Correlation table, description of .................. 91-93 Country rock, sulphide ore in .

Cow Creek, mine on.

Cowan, Yeilville formation near......

Crooked Creek, mines along.

Crooked Creek Valley, view across

Cushman, deep well at

Davis Creek, fault crossing .

Deformation in northern Arkansas, history of........ 32-33

Devonian formations, correlation of (and table)...

fossils of .

.... 100-101

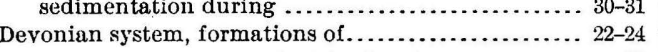

Dolomite, jointed, view of, plate showing..

Dolomite breccia, cemented with pink spar, view of plate showing

Dolomite spar, occurrence and character of...........

"Dry bone" form of Smithsonite, zine content of.....

Duff, Sylamore formation near

Dyson mine, description of .....

East Pigeon Creek, prospect on

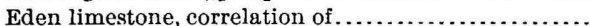

Eldorado mine, description of

Elixir prospect, description of.

character of.

Erosion in northern Arkansas,

Eureka shale, correlation of.

, history of.

xcelsior mine, description of .......................

St. Joe, fault near, view of mass of silicified breccia marking

Fault breccias, sulphide deposits in

Faults, date and character of

ayetteville, Batesville sandstone near..............

Morrow formation near

Pitkin limestone near....

Wedington sandstone near ..................

Fayetteville shale, age and stratigraphic place of . 100,107 character of ............................ 27, 107-108 correlation of ... 90

fossils of 106-107

ccurrence and thickness of.................

stratigraphic place of...................... 102-104

Featherstonhuugh, G. W., reference to .............. 13-14

Fernvale formation, stratigraphic place of ............

"Fool's gold," a name for pyrite.

Fort Payne chert, correlation of

Frisco property, description of ......................
40

40 Gart

aither Mountain, coal prospects at

Galena, occurrence and character of

Gambetta prospect, description of

Gangue minerals, character of plate showing.............................

fossils identified by ............................. 101

work projected by, on fauna of the Morrow formation.

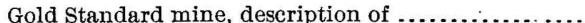

Gosiarite, occurrence and oharacter of .

42

Goswick prospect, description of .................. 84

Governor Eagle property, description of ............. $68-69$

Greenhaw Hollow, prospects in ................. 80-81

Ground water, circulation of, geologic conditions in-

$$
\text { fluencing ............................. 34-35 }
$$

Gypsum, occurrence and character of ................. 42

Halls Mountain, escarpment of, view showing......... 16

Harrison, mines near............................ 63-66

Hawkeye mine, description of....................

Hawkeye No. 1 prospect, description of............... 78

Hawkeye No. 2 mine, description of................... 79

Hayes, C. W., letter of transmittal by .................... 11

Hayes, C. W. and Ulrich, E. O., cited on conditions of deposition of Paleozoic formations in Tennessee ..............................

Hopeful prospect, description of ....................

Hulsenbeck mine, description of .................... view of, plate showing..

Hurricane fault, description of .

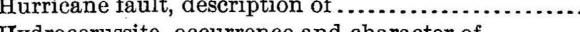

character of..........

Hydrozincite, occurrence and character of...........

Igneous rocks, nearest areas of .........................

open cut in barren ground near, view of, plate showing ................................

Iron sulphide, occurrence and character of ........

Iron sulphide, occurrence and character of ...........
Izard limestone, character, occurrence, and thickness of ..........

correlation of.

"Jack" See Zinc sulphide.

Jackpot (on Buffaio Fork) mine, description of....... 80

Jackpot property, description of.................... $65-66$

Jimmie Creek, mines near..................... 69-70, 70-71

Joachim limestone, stratigraphic place and equivalents of.............................. 96,97

Kessler limestone, correlation of .................. 90 equivalent of ................................. 28 stratigraphic place of.......................... $\quad 109$

Key sandstone, character, occurrence, and thickness of. 20-21

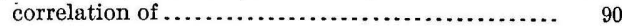

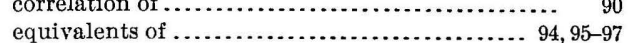
equivalents of $\ldots \ldots \ldots \ldots \ldots \ldots \ldots \ldots \ldots \ldots \ldots \ldots \ldots .9$.
fossils of $\ldots \ldots \ldots \ldots \ldots \ldots \ldots \ldots \ldots \ldots \ldots \ldots \ldots \ldots \ldots \ldots$ $\begin{array}{ll}\text { fossils of } \ldots \ldots \ldots \ldots \ldots \ldots \ldots \ldots \ldots \ldots & 95 \\ \text { ledge of, view of, plate showing } \ldots \ldots \ldots \ldots \ldots \ldots \ldots \ldots & 24\end{array}$ stratigraphic place of.......................... 94

view of, in open cut, Big Elephant mine, plate

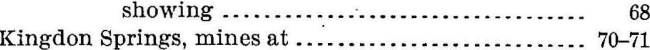

Lead carbonate, occurrence and character of ........ $\quad 40$ Lead Hill, ore smelted in vicinity of ................ 14

Lead ore, discovery of, history of .................. 13-14 Lead sulphide, occurrence and character of ......... 39 Little Rock, igneous rocks at........................... 30 Little Sugar Orchard Creek, mines near................ $68-69$ Lost mine, description of ......................... 78 McIntosh mill, description of .................... 47 view of, plate showing ........................... 74

Magnesian limestones, correlation of.................. 90 
Marble City prospect, description of. Marion County, mines and prospects in, description of. 66-78 Mark Hanna mine, description of

Markle Hollow, mine in...

Markle mine, description of hand jigs at, view of

Marshall, Batesville sandstone near...

Fayetteville shale near. character of

correlation of

90

106-107

Maryhattiana mine, description of................ 75

Maumee prospect, description of ........................ 80-81

Maxville limestone, correlation of

Meek, F. B., cited on Carboniferous fossils from Montena mines near prospects on

Mill Creek fault, description of..

Mines and prospects, description of

Mining and prospecting,

Mississippi Valley, ore deposits in, source of ......... $88-89$

Mississippian formations, character and fossils of... 101-109 correlation of.

Mississippian province, definition of (note) ...........

Mississippian series, deposition of, conditions of

formations of ............................... 24-28

Moccasin Creek, mines near....................... $70-71$

Monkey Run, prospects on ...

Moorefield shale, character, occurrence and thickness of correlation of ................................ 90 stratigraphic place of........................... 102-104

Morning Star mine, description of ................ 73-74 fault at

main cut at east end of, view of, plate showing .. 74

Morning Star mine and mill, views of, plates showing. $\quad 72$

Morrow formation, age of .................... 109-113 character, occurrence, and thickness of.......... 28 correlation of ........................... 90,109-113 fossils of ................................... 111

Mud Hollow prospects, description of .............. 81

Mundic, a name for pyrite .

Nakomis mine, description of view of, plate showing

Newton County, mines and prospects ini, descrit of ............ 82-85

Noel shale, character and thickness of................... 24-25, 101-102 correlation of............................ 23-24,90,101 fossils of ................................. 101-102

North Star mine, description gf

Northern Star mine, description of.................. 63-64

Ohioan province, time scale of ..

Old Granby mine, description of

Olympia mine, description of ...................... $83-84$

Ordovician formations, character and fossils of...... 93-98

Ordovician period, sedimentation during, conditions of .......................................

Ordovician rocks, correlation of, table of .............. Ordovician system, formations of ................. 18-22

Ore deposits, grouping of rocks with respect to ........ relations of, to synclines. source of, opinions of previous writers in regard

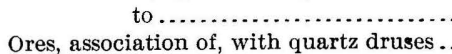

Ores, classification of

Page.

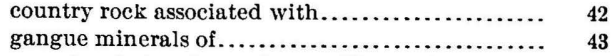
genesis of, hand specimens illustrating, plates showing ............... 48,50,52,54,56, 58, 60,62 minerals associated with .................... 41-42 source of......................................... $41-42$

Ores, oxidized, occurence and character of............ $39-41$ processes of deposition of........................ 44-45 Ores, sulphide, association of, with secondary chert .. 45

in bedded breccias ............................

in country rock................................ in fault breccias .....................................

in fissures.

occurrence and character of.

primary deposition of processes of

secondary deposition of, processes of ...............

value of ......................................

Ores and minerals, discussion of ................... 39-40

Oxidized ores, processes of deposition of ............. $44-45$

Ozark plateau, ancient topography of .............. 17-18

lowlands in ................................. 17

physiographic relations of.......................... 16

topographic features of ....................... 17

Ozark region, ore deposits in, source of................. 89

relations of, to Arkansas Valley and Wichita

Mountain regions, structure sections showing.

sketch maps of, showing drainage, physiography, and topography

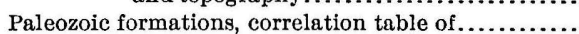

Panther Creek, mines and prospects on ........... 84-85

Panther Creel mine, description of

Panther Creek mine, description of................. 81-85

$\begin{array}{lr}\text { Pennsylvanian formations, correlation of............. } & 90 \\ \text { Pennsylvanian series, formations of................ } & 28-29\end{array}$

Pentremital limestone, correlation of................. 90

equivilents of ...

stratigraphic place of ....... 109, 112

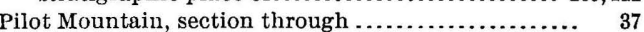

Pilot Mountain fault, description of ................... $37-38$ section showing ............................... 37

Pilot Rock prospect, description of ................. 68

Pink spar, occurrence and character of ............. 41

Pitkin limestone, age of ............................ 109

character, occurrence, and thickness of............. 27-28

correlation of ............................. 90, 109

Polk Bayou limestone, character, occurrence, and

$$
\text { thickness of ........................ }
$$

correlation of

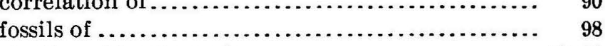

stratigraphic place of ............................ 97, 98

Ponca City prospect, description of................. $\quad 85$

Potosi limestone, equivalent of................... 95

Pottsville group, stratigraphic limits of .............. 110

Prospecting and mining, suggestions relating to ...... 85-86

Purdue, A. H., aid by............................ 13 cited on origin of zinc and lead deposits ........... 87

Pyrite, occurrence and character of ............... 41-42

Quartz, occurrence and character of ............... 41

Quartz druses, ore associated with ................... 46

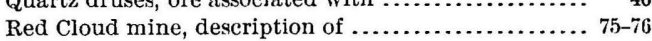
view of, plate showing ....................... 76

Richmond Bluff, view of, plate showing ............ 22

Ridley limestone, stratigraphic place of $\ldots$

Rush, Rush Creek fault near, section across............. section near ..................................

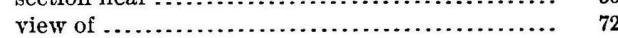


Rush Creek, mines and prospects on ................. Page. $73-75$ Rush Creek fault, description of...

section across

Saccharoidal sandstones, correlation of

Clair limestone, age and stratigraphic place of ... 98-100 correlation of

fossils of .

t. Frencis Mountains, igneous rocks in .

St. Joe, Sylamore formation near.................

St. Joe fault, description of........................ silicified breccia marking, view of, plate showing.

St. Joe fault and monocline, section across.

St. Joe limestone, ledge of, view of, plate showing . stratigraphic place of

St. Joe mine. See Excelsior mine.

St. Joe monocline, description of.

St. Louis limestone, stratigraphic place of ...........

St. Peter sandstone, equivalents of .

Salem upland, chargeter and exter

Sam Hill mine, description of

Schoolcraft, H. R., reference to explorations by ......... Searcy County, mines and prospects in, descriotion of Sedimentation in northern Arkansas, history of

Shaddock Branch, prospects near.

Shakopee limestone, stratigraphic place of.

Silicified breccia, marking St. Joe fault, view of .

Silurian formations, correlation of (and table)

fossils of

ilver Hollow mine, description of.

Simonds, F. W., cited on Batesville sandstone........

Smithsonite, occurrence and character of ............

Spar. See Dolomite spar; Pink spar.

Spavinaw, Ind. T., igneous rocks at..................

Tpholerite, metallic zinc in ...

view of, plate showing .

Spring Branch, fault line near

correlation of .

pringfield upland, character and extent of......... 17

Starlight mine, description of ......................

Stones River limestone, stratigraphic place of ....... 96, 97

Strawberyy River, lead mine on, reference to ........ 13-14

Sugar Orchard Creek, mines and prospects near..... mines near.

Sugarloaf Creek, mines near. ccurrence of, in bedded breccias.

in fault breccias.

in fissures.

in the country rock.

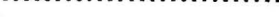

primary deposition of, processes of ...............

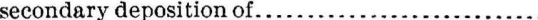

value of.

zinc and lead in, amount of

Summit Home mine, description of

Susquehanna mine, description of view of, plate showing

Sylamore formation, age of correlation of fossils of ................................... 100-101

Sylvan shrle, correlation of ...

Synclines, relations of
Tallow clay mine, description of ... Page.

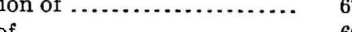

Tertiary epoch, crosion during ......................

Thebes formation, correlation of .

Tiff, occurrence and character of.....................

Tiff, occurrence and character of....................
Time scale, standard, of the Ohioan province, table...

Tomahawk fault, description of .................... 37

"Turkey fat" form of Smithsonite, cause of color of .. 40

Ulrich, E. O., determination and correlation of forma-

tions, paper on........................ 90-113

field work by ............................... 13

Unconformities, enumeration of.................. 92-93

Van Hise, C. R., and Bain, H. Foster, cited on origin of ore deposits of Mississippi Valley........ 88-89

Van Ingen, Gilbert, cited on fauna of St. Clair limestone.

$88-89$

Villines Creek, mines on............................

Viola limestone, correlation of.................... 97, 98

Virginia J. mine, description of ................... 66

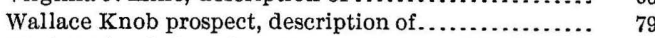

Washington shale and sandstone, stratigraphic place of. $\quad 109$

Water Creek, fold near ........................... $\quad 39$

prospects on ............................ 78, 80

Weathering, relations of, to cementation............ 35-36

Wedington sandstone, character, occurrence, and thickness of ...

correlation of . ...... 90

stratigraphic place of

Weller, Stuart B., Carboniferous fossils collected by .. 103 cited on fauna of Batesville sandstone .......... 104, 105 White, David, cited on age of coal-bearing shales..... 112 White Eagle mine, description of .................. 74, 75 view of, plate showing

White River, view of bottom land

Yellville formation on ........ 16

Yellville formation on ...........................
ichita Belle prospect, description of...............

Williams, H. S., cited on correlation of Carrollton limestone

cited on faun of St. Clair limeston..... 102

cited on Spring Creek limestone and its fauna... 102,103

cited on Spring Creek limestone and its fauna.. 102, 103
Willis mine, description of .......................... 64

Wilrockson, prospects near.......................... 83

Winchester mine, description of .................... 80

Winslow formation, character, occurrence, and thickness of

correlation of

Wyman sandstone, age of ............................

correlation of .

Yellville formation, character, occurrence, and thickness of ................................ 18-20

correlation of ...................................

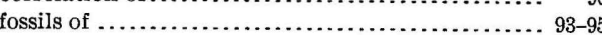

fracture zones in.--13

lower limit of ..................... 95

ore deposits in ...................................

topographic expression of .........................

Yellville quadrangle, area embraced by .............. 13

boundaries of ................................ 13

faults in, description of .......................... $36-39$

northern part of, geologic map of ................. 18

southern part of, geologic map of..................

Zinc Basin prospect, description of .....................

Zinc carbonate, occurrence and character of......... 40

Zinc ores, discovery of, reference to................. 14

Zinc silicate, occurrence and character of .............. $39-40$

Zine sulphide, metallic zinc in .................... 


\section{PUBLICATIONS OF UNITED STATES GEOLOGICAL SURVEY.}

[Professional Paper No. 24.]

The serial publications of the United States Geological Survey consist of (1) Annual Reports, (2) Monographs, (3) Professional Papers, (4) Bulletins, (5) Mineral Resources, (6) Water-Supply and Irrigation Papers, (7) Topographic Atlas of the United States-folios and separate sheets thereof, (8) Geologic Atlas of the United States-folios thereof. The classes numbered 2, 7, and 8 are sold at cost of publication; the others are distributed free. A circular giving complete lists may be had on application.

The Professional Papers, Bulletins, and Water-Supply Papers treat of a variety of subjects, and the total number issued is large. They have therefore been classified into the following series: A, Economic geology; B, Descriptive geology; C, Systematic geology and paleontology; D, Petrography and mineralogy; E, Chemistry and physics; F, Geography; G, Miscellaneous; H, Forestry; I, Irrigation; J, Water storage; K, Pumping water; L, Quality of water; M, General hydrographic investigations; N, Water power; O, Underground waters; P, Hydrographic progress reports. This paper is the thirty-first in Series A and the sixty-sixth in Series C, the complete lists of which follow. ( $\mathrm{PP}=$ Professional Paper, $\mathrm{B}=$ Bulletin, WS $=$ Water-Supply Paper. $)$

\section{SERIES A, ECONOMIC GEOLOGY.}

B 21. Lignites of Great Sioux Reservation: Report on region between Grand and Moreau rivers, Dakota, by Bailey Willis. 1885. 16 pp., 5 pls. (Out of stock.)

B 46. Nature and origin of deposits of phosphate of lime, by R. A. F. Penrose, jr., with introduction by N. S. Shaler. 1888. $143 \mathrm{pp}$. (Out of stock.)

B 65. Stratigraphy of the bituminous coal field of Pennsylvania, Ohio, and West Virginia, by I. C. White. $1891.212 \mathrm{pp}$. 11 pls. (Out of stock.)

B 111. Geology of Big Stone Gap coal field of Virginia and Kentucky, by M. R. Campbell. 1893.106 pp., 6 pls.

B 132. The disseminated lead ores of southeastern Missouri, by Arthur Winslow. $1896.31 \mathrm{pp}$.

B 138. Artesian-well prospects in Atlantic Coastal Plain region, by N. H. Darton. 1896. 228 pp., 19 pls. (Out of stock.)

B 139. Geology of Castle Mountain mining district, Montana, by W. H. Weed and L. V. Pirsson. $1896.164 \mathrm{pp} ., 17 \mathrm{pls}$

B 143. Bibliography of clays and the ceramic arts, by J. C. Branner. $1896.114 \mathrm{pp}$.

B 164. Reconnaissance on the Rio Grande coal fields of Texas, by T. W. Vaughan, including a report on igneous rocks from the San Carlos coal field, by E. C. E. Lord. 1900. 100 pp., 11 pls.

B 178. El Paso tin deposits, by W. H. Weed. 1901. 15 pp., 1 pl.

B 180. Occurrence and distribution of corundum in United States, by J. H. Pratt. 1901. 98 pp., 14 pls. (Out of stock.)

B 182. A report on the economic geology of the Silverton quadrangle, Colorado, by F. L. Ransome. $1901.266 \mathrm{pp} ., 16 \mathrm{pls}$ (Out of stock.)

B 184. Oil and gas fields of the western interior and northern Texas Coal Measures and of the Upper Cretaceous and Tertiary of the western Gulf coast, by G. I. Adams. 1901. 64 pp., 10 pls. (Out of stock.)

B 193. The geological relations and distribution of platinum and associated metals, by J. F. Kemp. $1902.95 \mathrm{pp} ., 6 \mathrm{pls}$ (Out of stock.)

B 198. The Berea grit oil sand in the Cadiz quadrangle, Ohio, by W. T. Griswold. 1902: $43 \mathrm{pp} ., 1 \mathrm{pl}$.

PP 1. Preliminary report on the Ketchikan mining district, Alaska, with an introductory sketch of the geology of southeastern Alaska, by Alfred Hulse Brooks. 1902.120 pp., 2 pls.

B 200. Reconnaissance of the borax deposits of Death Valley and Mohave Desert, by M. R. Campbell. $1902.23 \mathrm{pp} ., 1 \mathrm{pl}$ (Out of stock.)

B 202. Tests for gold and silver in shales from western Kansas, by Waldemar Lindgren. 1902.21 pp.

PP 2. Reconnaissance of the northwestern portion of Seward Peninsula, Alaska, by A. J. Collier. $1902.70 \mathrm{pp} ., 11 \mathrm{pls.}$

PP 10. Reconnaissance from Fort Hamlin to Kotzebue Sound, Alaska, by way of Dall, Kanuti, Allen, and Kowak rivers, by W. C. Mendenhall. 1902.68 pp., 10 pls.

PP 11. Clays of the United States east of the Mississippi River, by Heinrich Ries. 1903.298 pp., 9 pls.

PP 12. Geology of the Globe copper district, Arizona, by F. L. Ransome. $1903.168 \mathrm{pp} ., 27 \mathrm{pls}$.

B 212. Oil fields of the Texas-Louisiana Gulf Coastal Plain, by C. W. Hayes and William Kennedy. $1903.174 \mathrm{pp} ., 11 \mathrm{pls.}$

B. 213. Contributions to economic geology, 1902. S. F. Emmons, C. W. Hayes, geologists in charge. 1903.449 pp.

PP 15. The mineral resources of the Mount Wrangell district, Alaska, by W. C. Mendenhall and F. C. Schrader. 1903. 71 pp., 10 pls.

B 218. Cosl resources of the Yukon, Alaska, by Arthur J. Collier. 1903. 71 pp., 6 pls.

B 219. The ore deposits of Tonopah, Nevada (preliminary report), by J. E. Spurr. 1903. 31 pp., 1 pl.

PP 20. A reconnaissance in northern Alaska in 1901, by F. C. Schrader. 1904.139 pp., 16 pls.

PP 21. The geology and ore deposits of the Bisbee quadrangle, Arizona, by F. L. Ransome. $1904.168 \mathrm{pp} ., 29 \mathrm{pls}$

B 223. Gypsum deposits in the United States, by G. I. Adams and others. 1904.129 pp., 21 pls.

PP 24. Zinc and lead deposits of northern Arkansas, br G. I. Adams, assisted by A. H. Purdue and E. F. Burchard, with a section on the determination and correlation of formations, by E. O. Ulich. 1904.118 pp:, 27 pls. 
SERIES C, SYSTEMATIC GEOLOGY AND PALEONTOLOGY.

B 3. Fossil faunas of Upper Devonian, along the meridian $76^{\circ} 30^{\prime}$, from Tompkins County, New York, to Bradford County, Pennsylvania, by H. S. Williams. $1884 . \quad 36 \mathrm{pp.} \quad$ (Out of stock.)

B 4. Mesozoic fossils, by C. A. White. $1884.36 \mathrm{pp} ., 9$ pls. (Out of stock.)

B 10. Cambrian faunas of North America; preliminary studies, by C. D. Walcott. $1884.74 \mathrm{pp} ., 10 \mathrm{pls.}$ (Out of stock.)

$B$ 11. Quaternary and recent Mollusca of the Great Basin, with descriptions of new forms, by R. Ellsworth Call. Introduced by a sketch of the Quaternary lakes of the Great Basin, by G. K. Gilbert. 1884.66 pp., 6 pls.

B 15. Mesozoic and Cenozoic paleontology of California, by C. A. White. 1885 . 33 pp. (Out of stock.)

B 16. Higher Devonian faunas of Ontario County, New York, by J. M. Clarke. 1885.86 pp., 3 pls.

B 18. Marine Eocene, fresh-water Miocene, and other fossil Mollusca of western North America, by C. A. White. 1.885. 26 pp., 3 pls.

B 19. Notes on the stratigraphy of California, by G. F. Becker. $1885.28 \mathrm{pp.} \mathrm{(Out} \mathrm{of} \mathrm{stock.)}$

B 22. New Cretaceous fossils from California, by C. A. White. 1885.25 pp., 5 pls. (Out of stock.)

B 24. List of marine Mollusca, comprising the Quaternary fossils and Recent forms from American localities between Cape Futteras and Cape Roque, including the Bermudas, by W. H. Dall. 1885 . $336 \mathrm{pp}$.

B 29. Fresh-water invertebrates of the North American Jurassic, by C. A. White. $41 \mathrm{pp} ., 4 \mathrm{pls}$.

B 30. Second contribution to the studies on the Cambrian faunas of North America, by C. D. Walcott. $1886 . \quad 369$ pp., 33 pls. (Out of stock.)

B 31. Systemutic review of our present knowledge of fossil insects, including myriapods and arachnids, by S. H. Scudder. 1886. $128 \mathrm{pp}$.

B 34. Relation of the Laramie molluscan fauna to that of the succeeding fresh-water Eocene and other groups, by C. A. White. $1886.54 \mathrm{pp}, 5 \mathrm{pls}$.

B 37. Types of the Laramie flora, by L. F. Ward. 1887 . 354 pp., $57 \mathrm{pls}$.

B 41. Fossil faunas of the Upper Devonian-the Genesee section, New York, by H. S. Williams. 1887. 121 pp., 4 pls. (Out of stock.)

B 43. Tertiary and Cretaceous strata of the Tuscaloosa, Tombigbee, and Alabama rivers, by E. A. Smith and L. C. Johnson. 1887. 189 pp., 21 pls.

B 51. Invertebrate fossils from the Pacific coast, by C. A. White. $1889.102 \mathrm{pp} ., 14 \mathrm{pls.}$ (Out of stock.)

B 56. Fossil wood and lignite of the Potomac formation, by F. H. Knowlton. 1889.72 pp., 7 pls.

B 63. Bibliography of Paleozoic Crustacea from 1698 to 1889, including a list of North American species, and a systematic arrangement of genera, by A. W. Vogdes. $1890.177 \mathrm{pp}$.

B 69. Classed and annotated bibliography of fossil insects, by S. H. Scudder. $1890.101 \mathrm{pp.}$

B 71. Index to known fossil insects of the world, including myriapods and arachnids, by S. H. Scudder. $1891.744 \mathrm{pp.}$

B 77. The Texan Permian and its Mesozoic types of fossils, by C. A. White. 1891.51 pp., 4 pls.

B 80. Correlation papers-Devonian and Carboniferous, by H. S. Williams. 1891. $279 \mathrm{pp}$. (Out of stock.)

B 81. Correlation papers-Cambrian, by C. D. Walcott. 1891.447 pp., 3 pls. (Out of stock.)

B 82. Correlation papers-Cretaceous, by C. A. White. 1891. 273 pp., 3 pls. (Out of stock.)

B 83. Correlation papers-Eocene, by W. B. Clark. 1891. 173 pp., 2 pls.

B 84. Correlation papers-Neocene, by W. H. Dall and G. D. Harris, 1892.349 pp., 3 pls. (Out of stock.)

B 85. Correlation papers-The Newark system, by I. C. Russell. 1892.344 pp., 13 pls. (Out of stock.)

B 86. Correlation papers-Archean and Algonkian, by C. R. Van Hise. 1892.549 pp., 12 pls. (Out of stock.)

B 87. Synopsis of American fossil Brachiopoda, including bibliography and synonymy, by Charles Schuchert. 1897. $464 \mathrm{pp}$.

B 88. Cretaceous Foraminifera of New Jersey, by R. M. Bagg, jr. 1898.89 pp., 6 pls.

B 93. Some insects of special interest from Florissant, Colo., and other points in the Tertiaries of Colorado and Utah, by S. H. Scudder. 1892.35 pp., 3 pls. (Out of stock.)

B 97. Mesozoic Echinodermata of the United States, by W. B. Clark. 1893.207 pp., 50 pls.

B 98. Flora of the outlying Carboniferous basins of southwestern Missouri, by David White. $1893.139 \mathrm{pp} ., 5 \mathrm{pls}$.

B 101. Insect fauna of the Rhode Island coal field, by S. H. Scudder. 1893.27 pp., 2 pls.

B 102. Catalogue and bibliography of North American Mesozoic Invertebrata, by C. B. Boyle. $1893.315 \mathrm{pp}$.

B 105. The Laramie and the overlying Livingston formation in Montana, by W. H. Weed, with report on flora, by F. H. Knowlton. 1893. 68 pp., 6 pls.

B 106. Colorado formation and its invertebrate fauna, by T. W. Stanton. $1893.288 \mathrm{pp}, 45 \mathrm{pls}$. (Out of stock.)

B 110. Paleozoic section in the vicinity of Three Forks, Mont., by A. C. Peale. $1893.56 \mathrm{pp} ., 6 \mathrm{pls}$.

B 120. Devonian system of eastern Pennsylvania and New York, by C. S. Prosser, 1895, 81 pp., 2 pls. (Out of stock.)

B 121. Bibliography of North American paleontology, by C. R. Keyes. $1894.251 \mathrm{pp}$.

B 124. Revision of North American fossil cockroaches, by S. H. Scudder. $1895.176 \mathrm{pp} ., 12 \mathrm{pls}$.

B 128. Bear River formation and its characteristic fauna, by C. A. White. 1895.108 pp., 11 pls.

B 133. Contributions to the Cretaceous paleontology of the Pacific coast: The fauna of the Knoxville beds, by T. W. Stanton. 1895. $132 \mathrm{pp} ., 20 \mathrm{pls}$.

B 134. Cambrian rocks of Pennsylvania, by C. D. Walcott. 1896.43 pp., 15 pls.

B 141. Eocene deposits of the middle Atlantic slope in Delaware, Maryland, and Virginia, by W. B. Clark. 1896.167 pp., 40 pls.

B 142. Brief contribution to the geology and paleontology of northwestern Louisiana, by T. W. Vaughan. 1896.65 pp., 4 pls.

B 145. Potomac formation in Virginia, by W. M. Fontaine. 1896.149 pp., 2 pls.

B 151. Lower Cretaceous gryphæas of the Texas region, by R. T. Hill and T. W. Vaughan. 1898.139 pp., 35 pls.

B 152. Catalogue of Cretaceous and Tertiary plants of North America, by F. H. Knowlton. 1898. $247 \mathrm{pp}$. 
B 153. Bibliographic index of North American Carboniferous invertebrates, by Stuart Weller. $1898.653 \mathrm{pp.}$

B 163. Flora of the Montana formation, by F. H. Knowlton. 1900.118 pp., 19 pls.

B 173. Synopsis of American fossil Bryozoa, including bibliography and synonymy, by J. M. Nickles and R. S. Bassler. 1900. $663 \mathrm{pp}$.

B 179. Bibliography and catalogue of fossil Vertebrata of North America, by O. P. Hay. $1902.868 \mathrm{pp}$

B 191. North American geologic formation names: Bibliography, synonymy, and distribution, by F. B. Weeks. $1902.448 \mathrm{pp}$ B 195. Structural details in the Green Mountain region and in eastern New York (second paper), by T. Nelson Dale. 1902 22 pp., 4 pls.

B 204. Fossil flora of the John Day Basin, Oregon, by F. H. Knowlton. 1902.153 pp., 17 pls.

B 205. The Mollusca of the Buda limestone, by G. B. Shattuck, with an appendix on the corals of the Buda limestone, by T. W. Vaughan. 1903. $94 \mathrm{pp} ., 27 \mathrm{pls}$

B 206. A study of the fauna of the Hamilton formation of the Cayuga Lake section in central New York, by H. F. Cleland. 1903. 112 pp., 5 pls.

B 210. The correlation of geological faunas; a contribution to Devonian paleontology, by H. S. Williams. $1903.147 \mathrm{pp} ., 1 \mathrm{pl}$ B 211. Stratigraphy and paleontology of the Upper Carboniferous rocks of the Kansas section, by G. I. Adams, G. H. Girty, and David White. 1903. 123 pp., 4 pls.

PP16. Carboniferous formations and faunas of Colorado, by G. H. Girty. $1903.546 \mathrm{pp} ., 10 \mathrm{pls}$

PP19. Contributions to the geology of Washington, by G. O. Smith and Bailey Willis. $1903.101 \mathrm{pp} ., 20 \mathrm{pls}$.

PP 21. The geology and ore deposits of the Bisbee quadrangle, Arizona, by F. L. Ransome. 1904.168 pp., 29 pls.

PP 24. Zinc and lead deposits of northern Arkansas, by G. I. Adams, assisted by A. H. Purdue and E. F. Burchard, with \& section on the determination and correlation of formations, by E. O. Ulrich. $1904,118 \mathrm{pp}$., $27 \mathrm{pls}$

Correspondence should be addressed to

The Director

United States Geological Survey,

WASHINGTON, D. C.

JunE, 1904

4538-No. $24-04-9$ 



\section{LIBRARY CATALOGUE SLIPS.}

[Mount each slip upon a separate card, placing the subject at the top of the second slip. The name of the series should not be repeated on the series card, but additional numbers should be added, as received, to the first entry.]

\section{Adams, George I [rving]}

... Zinc and lead deposits of northern Arkansas, by George I. Adams, assisted by A. H. Purdue and E. F. Burchard, with a section on the determination and correlation of formations, by E. O. Ulrich. Washington, Gov't print. off., I904.

118, V p. illus., $27 \mathrm{pl}$. (incl. maps). $29 \frac{1}{2} \times 23^{\text {om }}$. (U. S. Geological survey. Professional paper no. 24.)

Subject series: A, Economic geology, 31; C, Systematic geology and paleontology, 66 .

\section{Adams, George I [rving]}

... Zinc and lead deposits of northern Arkansas, by George I. Adams, assisted by A. H. Purdue and E. F. Burchard, with a section on the determination and correlation of formations, by $\mathrm{E}$. O. Ulrich. Washington, Gov't print. off., I904.

$118, \mathrm{~V}$ p. illus., $27 \mathrm{pl}$. (incl. maps). $29 \frac{1}{2} \times 23^{\mathrm{cm}}$. (U. S. Geological survey. Professional paper no. 24.)

Subject series: A, Economic geology, 31; C, Systematic geology and paleontology, 66 .

\section{U. S. Geological survey.}

Professional papers.

产 ern Arkansas, by G. I. Adams, assisted by A. H. Purdue and E. F. Burchard, with a section on the determination and correlation of formations, by E. O. Ulrich. I904.

\section{U. S. Dept. of the Interior.}

see also

U. S. Geological survey. 


